Keina Poliana Pivarro Dalmolin

\title{
Clonagem de um alelo do gene SPT15 em Saccharomyces cerevisiae para aumento da produção de etanol
}

Dissertação apresentada ao Programa de Pós-Graduação Interunidades em Biotecnologia USP/Instituto Butantan/IPT, para obtenção do Título de Mestre em Biotecnologia. 
Keina Poliana Pivarro Dalmolin

\section{Clonagem de um alelo do gene SPT15 em Saccharomyces cerevisiae para aumento da produção de etanol}

Dissertação apresentada ao Programa de Pós-Graduação Interunidades em Biotecnologia USP/Instituto Butantan/IPT, para obtenção do Título de Mestre em Biotecnologia.

Área de concentração: Biotecnologia

Orientador (a):

Prof $^{\mathrm{a}}$ Dra. Elisabete José Vicente

São Paulo

2011 
DADOS DE CATALOGAÇÃO NA PUBLICAÇÃO (CIP)

Serviço de Biblioteca e Informação Biomédica do

Instituto de Ciências Biomédicas da Universidade de São Paulo

(C) reprodução total

Dalmolin, Keina Poliana.

Clonagem de um alelo do gene SPT15 em Saccharomyces cerevisiae para aumento da produção de etanol / Keina Poliana Dalmolin. -- São Paulo, 2010.

Orientador: Elisabete Jose Vicente.

Dissertação (Mestrado) - Universidade de São Paulo. Instituto de Ciências Biomédicas. Programa de Pós-Graduação Interunidades em Biotecnologia USP/IPT/Instituto Butantan. Área de concentração:

Biotecnologia. Linha de pesquisa: Melhoramento genético de levedura para produção de etanol

Versão do título para o inglês: Cloning of an SPT15 allele gene in Saccharomyces cerevisiae for the increasing of ethanol production.

Descritores: 1. Saccharomyces cerevisiae 2. Etanol 3. Gene SPT15 4. Glicose I. Vicente, Elisabete Jose II. Universidade de São Paulo. Instituto de Ciências Biomédicas. Programa de Pós-Graduação Interunidades em Biotecnologia USP/IPT/Instituto Butantan III. Título. 
Candidato(a): $\quad$ Keina Poliana Dalmolin.

Título da Dissertação: $\quad$ Clonagem de um alelo do gene SPT15 em Saccharomyces cerevisiae para aumento da produção de etanol.

Orientador(a): $\quad$ Elisabete Jose Vicente.

A Comissão Julgadora dos trabalhos de Defesa da Dissertação de Mestrado, em sessão pública realizada a ....................................
( ) Aprovado(a)
( ) Reprovado(a)

Examinador(a): Assinatura:

Nome:

Instituição:

Examinador(a): Assinatura:

Nome:

Instituição:

Presidente: Assinatura:

Nome:

Instituição: 


\section{CERTIFICADO DE ISENÇÃO}

Certificamos que o Protocolo CEP-ICB N³90/10 referente ao projeto intitulado: "Clonagem do gene SPT15 em linhagens de levedura industriais para aumento da produção de etanol" sob a responsabilidade de Keina Poliana Pivarro Dalmolin, foi analisado na presente data pela CEUA - COMISSÃO DE ÉTICA NO LSO DE ANIMAIS e pela CEPSH- COMISSÃO DE ÉTICA EM PESQUTSA COM SERES HUMLNOS, tendo sido deliberado que o referido projeto não envolve manipulação animal ou humana que justifique uma aprovação quanto aos princípios éticos exigidos por ambas as Comissões.

São Paulo, 21 de junho de 2010.

PROF. DR. WOTHAN TAVARES DE LIMA Coordenador da CEUA - ICB/USP
PRof. DR. PAOI, M.A ZANOTTO Coordenador da CEPsh - ICB/USP 
Aos meus queridos pais Lourival e Neiva e, ao meu noivo Ivan, por todo amor, dedicação, compreensão e paciência durante mais este caminho tão importante em minha vida. 


\section{AGRADECIMENTOS}

Á professora Dra. Elisabete José Vicente pela oportunidade, confiança e orientação profissional e pessoal.

À professora Dra. Ana Clara Guerrini Schenberg pela atenção e colaboração científica.

Aos meus colegas do laboratório: Ana Cristina, Belisa, Claudionor, Cleide, Ciça, Fábio, e Oeber pela colaboração e por tudo ao longo deste período.

À Raquel, por ser mais que uma colega, ser uma amiga para todas as horas, Quel obrigada por toda a orientação e pelas palavras de apoio constantes.

À Carol e Jessi pela amizade, carinho, apoio e os bons momentos de convívio.

À Leninha, Kazui e Norma pelo auxílio e apoio técnico necessário.

Aos secretários do Programa de Pós Graduação Interunidades em Biotecnologia USP/Instituto Butantã/IB/ICB/IPT, pela compreensão e ajuda.

Aos funcionários da biblioteca do ICB/USP pela atenção e correções.

À minha querida família (meus pais, meu irmão, meus tios e tias, em especial Tia Dri e Wilma, que sempre se preocuparam comigo e me deram apoio, meus primos, em especial minha tão linda priminha: Loli, que sempre me ligou me fazendo rir, meu adorado e sincero sobrinho: Guto, quem sempre me ligava para pedir um "presentinho" e aos meus avós, pelas palavras de carinho) por todo seu amor e mesmo distante pelo apoio incondicional, pela força a cada momento de tristeza, pois onde quer que eu esteja, sei que jamais estarei sozinha. Obrigada por tudo!!!! Amo cada um de vocês.

Ao meu grande e eterno amor Ivan, que sempre me encorajou com suas palavras amigas, sua confiança plena em mim e seu carinho em todos os momentos da minha vida. A sua presença e companheirismo foram cruciais para a realização deste trabalho. 
"Linda menina abra as asas

Voe o mais alto que puder

Acredite você pode ir ainda mais alto

Feche os olhos, imagine-se

Nunca olhe para baixo

De a mão ao céu

Alcance o universo, almeje o infinito

Transpasse as barreiras da realidade e siga seu coração".

Daniel Lessa 


\section{RESUMO}

Dalmolin KPP. Clonagem de um alelo do gene SPT15 em Saccharomyces cerevisiae para aumento da produção de etanol [dissertação (Mestrado em Biotecnologia)]. São Paulo (Brasil): Instituto de Ciências Biomédicas da Universidade de São Paulo; 2010.

Em 2006, Alper e colaboradores trabalharam com a maquinaria de transcrição global da linhagem haplóide de levedura S. cerevisiae BY4741 e demonstraram que uma linhagem recombinante portadora de cópias adicionais de um alelo codificador do fator de transcrição SPT15 mutagenizado em três diferentes posições ( $P h{ }^{177}$ Ser, serina da posição 177 substituída por fenilalanina; similarmente, $\mathrm{Tyr}^{195} \mathrm{His}$, e $\mathrm{Lys}{ }^{218} \mathrm{Arg}$ ), denominado alelo spt15300, presentes em plasmídeo de múltiplas cópias, passa a utilizar mais rapidamente a glicose, e apresenta aumento do rendimento de produção de etanol em 15\%. Considerandose que, o Brasil é um dos maiores produtores e exportadores de etanol combustível do mundo, o melhoramento genético de linhagens $S$. cerevisiae visando o aumento de capacidade de produção de etanol é extremamente relevante. Neste trabalho, foi realizada a clonagem de uma cópia do alelo spt15-300, aqui chamado spt15*. Para tanto, inicialmente o DNA genômico da linhagem S. cerevisiae S288C foi extraído, purificado e utilizado como molde para amplificação por SOEing-PCR. O alelo triplo mutado spt $15^{*}$ foi clonado inicialmente no plasmídeo comercial pGEMT-Easy e, em seguida, introduzido no plasmídeo epissomal pMA91, onde passou a ser expresso sob a regulação do promotor e terminador de transcrição da fosfoglicerato quinase (PGK) de S. cerevisiae (plasmídeo pMA91spt15*). Após várias etapas de construções moleculares, foi obtido o fragmento de DNA $\delta$ pPGKspt $15 *$ PGK $\delta$, para ser empregado na transformação genética, por $\delta$ integração, de linhagens $S$. cerevisiae de laboratório. Os transformantes da linhagem $S$. cerevisiae YPH252 foram selecionados por complementação gênica do fenótipo Leu+. Verificou-se que, em relação à linhagem hospedeira YPH252, os clones recombinantes YHP252/pMA91spt $15 *$ e YHP252/8pPGKspt $15 *$ tPGK $\delta$ consomem de maneira mais eficiente a glicose e aumentam o rendimento de produção de etanol. Ainda, o seqüenciamento do alelo SPT15 da levedura industrial PE-2, obtido por amplificação por PCR, revelou que este apresenta $100 \%$ de identidade com o alelo presente nas linhagens BY4741 e S288C. Isto permite que se criem ótimas perspectivas para um trabalho futuro de inserção de cópias do alelo spt $15^{*}$ no genoma das linhagens $S$. cerevisiae industriais, por $\delta$ integração.

Palavras-chave: Fator de transcrição global de S. cerevisiae. Produção de etanol. Gene SPT15. $\delta$-integração. 


\begin{abstract}
Dalmolin KPP. Cloning of an SPT15 allele gene in Saccharomyces cerevisiae for the increasing of ethanol production. [Master thesis (Biotechnology)]. São Paulo (Brasil): Instituto de Ciências Biomédicas da Universidade de São Paulo; 2010.

In 2006 Alper and his colleagues worked with the global transcription machinery of the yeast haploid strain $S$. cerevisiae BY4741 and proved that a recombinant strain carrying additional copies of a transcription factor SPT15-encoding allele mutagenized in three different positions ( $\mathrm{Phe}{ }^{177} \mathrm{Ser}$, serine in the position 177 replaced by phenylalanine; similarly, $\mathrm{Tyr}^{195} \mathrm{His}$ and $\mathrm{Lys}^{218} \mathrm{Arg}$ ), called spt15-300 allele, present on the multicopy plasmid, uses glucose more speedily and renders the ethanol production income $15 \%$ larger. Considering that Brazil is one of the world's greatest producers and exporters of ethanol fuel, the genetic improvement of the $S$. cerevisiae strains aiming at increasing the production capacity of ethanol is extremely important. In the present work, it has been performed the cloning of a copy of the spt15-300 allele, here called spt15*. In order to do that, the genomic DNA of the S. cerevisiae S288C strain was extracted, purified and used as a mold for the amplification through SOEing PCR. The spt15* triple-mutated allele was initially cloned in the commercial plasmid pGEMT-Easy and next introduced in the episomal plasmid pMA91, where it began to be expressed under the regulation of the transcription promoter and terminator of $S$. cerevisiae (plasmid pMA91spt15*) phosphoglycerate kinase (PGK). After many phases of molecular constructions the DNA $\delta$ pPGKspt $15 *$ tPGK $\delta$ fragment was obtained to be employed in the genetic transformation of laboratory S. cerevisiae strains using $\delta$-integration. The $S$. cerevisiae strain transformants were selected through genetic complementation of the phenotype $\mathrm{Leu}^{+}$. It could be observed that, in relation to the host strain YPH252, the recombinant clones YHP252/pMA91 spt15*

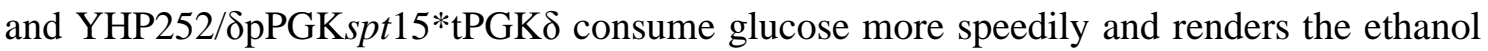
production larger. Furthermore, the allele SPT15 sequencing of the industrial yeast PE-2, obtained through PCR amplification, revealed that the latter presents an identity rate of $100 \%$ with the allele present in the strains BY4741 and S288C. This allows the creation of optimum perspectives for a future work concerning the insertion of copies of the spt15* allele in the genome of the industrial $S$. cerevisiae strains using $\delta$-integration.
\end{abstract}

Key words: $S$. cerevisiae global transcription factor. Ethanol production. SPT15 gene. $\delta$ integration. 


\section{LISTA DE ILUSTRAÇÕES}

Figura 1. Esquema geral da estrutura de um gene de eucariotos

Figura 2. Esquema linear e representação da estrutura da Proteína TATA-binding (TBP)

Figura 3. Esquema das três mutações (F177S, Y195 e K218) na proteína Spt15 e seu efeito na maquinaria de transcrição global da levedura $\mathrm{S}$. cerevisiae.

Figura 4A. Esquema do SOEing PCR, construído a partir de Heckman e Pease, 2007.....

Figura 4B. Esquema da técnica SOEing-PCR, para obtenção do gene triplo mutado spt15*, onde o fragmento 1 foi obtido com os oligonucleotídeos: $\mathrm{KPP} 1_{\mathrm{Fw}}+$ $\mathrm{KPP} 2_{\mathrm{Rv}}$ e possui $564 \mathrm{pb}$ e o fragmento 2 foi obtido com os oligonucleotídeos: $\mathrm{KPP} 3_{\mathrm{Fw}}+\mathrm{KPP} 4_{\mathrm{Rv}}$ e possui $186 \mathrm{pb}$. Ambos os fragmentos 1 e 2 foram usados como iniciadores e DNA molde para obtenção do fragmento 3 (spt5* que possui $750 \mathrm{pb}$ ) empregando-se os

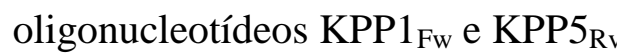

Figura 5. Fragmento de DNA das etapas de construção de $s p t 15 *$ em géis de agarose $0,8 \%$ corado com brometo de etídio, submetida à eletroforese: A) 1) $100 \mathrm{pb}$ DNA RULLER Fermentas (150 ng); 2 ao 5) Amplicon Fragmento 1, com $564 \mathrm{pb}$ que possui a mutação codificadora $\mathrm{Phe}^{177} \mathrm{Ser}$ (serina localizada na posição 177 substituída pela fenilalanina); 6) Controle negativo da PCR. B) 1) 100 pb DNA RULLER Fermentas (150 ng); 2 ao 5) Amplicon Fragmento 2, com $186 \mathrm{pb}$ que possui as mutações codificadoras $\mathrm{Tyr}^{195} \mathrm{His}$, Lys ${ }^{218} \mathrm{Arg}$ (histidina localizada na posição 195 foi substituída pela tirosina e a arginina localizada na posição 218 foi substituída pela lisina, respectivamente); 6) Controle negativo da PCR. C) 1) 100 pb DNA RULLER Fermentas (150 ng); 2) Padrão de tamanho molecular Fermentas (50 ng/ $\mu \mathrm{L}) ; 3$ ao 7) Amplicon do fragmento 3, com 750 pb que possui a tripla mutação e as extremidades dos oligonucleotídeos KPP1 e KPP5 possuem as sequências nucleotídicas reconhecidas pela enzima de restrição BamHI, onde os fragmentos 1 e 2 foram usados como DNA moldes; 8) Controle negativo da PCR. 
Figura 6. Esquema de clonagem do alelo SPT15 triplo mutado (spt15*) em vetor comercial pGEM-TEasy

da Promega.

Figura 7. Perfis de migração em gel de agarose $0,8 \%$, corado com brometo de etídio e submetido à eletroforese de: 1) marcador de tamanho $1 \mathrm{~Kb}$ DNA Ladder (Fermentas) $(50 \mu \mathrm{g}) ; 2)$ vetor pGEM-TEasy e linearizado pela enzima de restrição BamHI; 3, 4 e 5) plasmídeo recombinante pGEM TEasyspt15*, isolado de diferentes clones digerido com a enzima de restrição BamHI, onde a banda de $750 \mathrm{pb}$ se refere ao gene $\operatorname{spt} 15^{*}$ e a de $3015 \mathrm{pb}$ se refere ao plasmídeo comercial pGEM-TEasy.

Figura 8. Esquema da clonagem do gene triplo mutado spt $15 *$ no vetor epissomal pMA91

Figura 9. Perfis de migração em gel de agarose $0,8 \%$ corado com brometo de etídio e submetido à eletroforese das digestões do plasmídeo pMA91spt15* e PCR usando como molde pMA91spt15* e os oligonucleotídeos kppl e kpp5 $(\operatorname{spt15*}) .1)$ plasmídeo recombinante pMA91spt15* digerido com a enzima de restrição $B g l \mathrm{II} ; 2)$ plasmídeo recombinante pMA91spt15* digerido com a enzima de restrição HindIII; 3) plasmídeo recombinante pMA91spt15* digerido com a enzima de restrição XbaI. 4) marcador de tamanho $1 \mathrm{~Kb}$ Ladder $\left(\right.$ Fermentas $\left.^{\mathrm{R}}\right)(50 \mu \mathrm{g})$

Figura 10. Esquema da clonagem do cassete de expressão (pPGKspt15*tPGK) no vetor comercial $\quad \mathrm{pCR}^{\circledR} 2.1-\mathrm{TOPO}^{\circledR}$ (Invitrogen ${ }^{\mathrm{TM}}$ )

Figura 11. Perfis de migração em gel de agarose $0,8 \%$ corado com brometo de etídio e submetido à eletroforese das digestões do plasmídeo TOPOcasspt15* digerido com a enzima de restrição BamHI; 1) marcador $1 \mathrm{~Kb}$ Ladder (50 ng); 2) plasmídeo recombinante (TOPOcassetespt $15^{*}$ ) digerido com a enzima de restrição BamHI, onde a banda de $2615 \mathrm{pb}$ se refere ao cassete spt $15^{*}$ e a de $3900 \mathrm{pb}$ se refere ao plasmídeo $\mathrm{pCR}^{\circledR} 2.1-\mathrm{TOPO}^{\circledR}$ (Invitrogen $\left.{ }^{\mathrm{TM}}\right)$......

Figura 12. Esquema da clonagem do cassete de expressão (pPGKspt15*tPGK) no vetor integrativo pGEMT-Easy $\delta$ BamHI, possuindo $5964 \mathrm{pb}$ e denominado pGEMTEasy $\delta$ Bamcasspt 15 *. 
Figura 13. Perfis de migração em gel de agarose $0,8 \%$ corado com brometo de etídio e submetido à eletroforese de: 1 e 2) plasmídeo pGEMTEasy $\delta$ Bamcasspt15* digerido com a enzima BamHI (fragmento de DNA de 3348 pb e 2615 pb). 3) marcador de $1 \mathrm{~Kb}$ Ladder. 4 e 5) pGEMT-Easy $\delta$ BamHIcas.spt5* digerido com a enzima BglII (vetor linearizado com 5964 $\mathrm{pb})$.

Figura 14. Perfis de migração em gel de agarose $0,8 \%$ corado com brometo de etídio e submetido à eletroforese da digestão do plasmídeo pGEMT-Easy $\delta$ BamHI com a enzima de restrição EcoRI: 1) marcador de $1 \mathrm{~Kb}$ Ladder e 2) análise

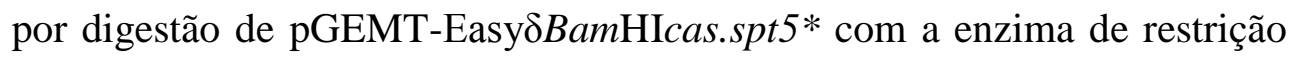
EcoRI, fragmento de DNA $\delta$ PPGKspt15*tPGK $\delta$ (2615 pb) e plasmídeo pGEMT-Easy $\delta$ Bam $\mathrm{HI}$ $\mathrm{pb})$.

Figura 15. Perfís de migração em gel de agarose $0,8 \%$ corado com brometo de etídio, submetido a eletroforese do fragmento "SpPGKspt15*tPGK $\delta$ " obtido por amplificação por PCR a partir de: 1) plasmídeo pGEMTEasySBamcasspt15*; 2) DNA total isolado do clone da linhagem de levedura YPH252 transformada com o fragmento $\delta$ pPGKspt15*tPGK $\delta$; 3 ) $1 \mathrm{~Kb}$ DNA Ladder Fermentas (150 ng) e 4) Controle negativo das amplificações por PCR.

Figura 16. Ensaio de fermentação da linhagem YPH252 transformada com os plasmídeos pMA91 (controle) e pMA91spt15* (Figura 11); e, como o fragmento $\delta$ pPGKspt $15 *$ tPGK $\delta$ (Figura 15). Os ensaios foram realizados em meio SD-THUAL 5\% glicose em tubos contendo tubo Durhan, incubados em estufa, a $28^{\circ} \mathrm{C}$ e observados a cada 12 horas de incubação. Foto da análise biológica de fermentação depois de incubação por: 24 horas; onde se observa a fermentação; B) 36 horas, onde também foi observada a fermentação da linhagem recombinante YPH252/pMA91spt15*; C) 48 horas, na qual ocorreu fermentação da linhagem YPH252/pMA91; D) Foto do ensaio de fermentação depois de 60 horas de incubação.

Figura 17. Ensaio de fermentação da linhagem YPH252 transformada com os plasmídeos pMA91 (controle) e pMA91spt15* (Figura 11); e, e o fragmento

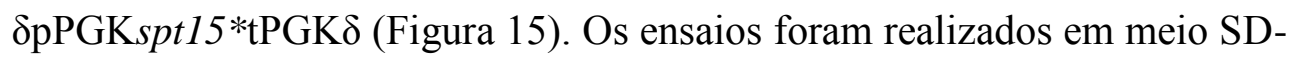
THUAL 20\% glicose em tubo contendo tubo Durhan, incubados em estufa, 
a $28{ }^{\circ} \mathrm{C}$ e observados a cada 12 horas de incubação. Foto da análise biológica de fermentação depois de incubação por: 24 horas, onde foi observada a fermentação da linhagem recombinante

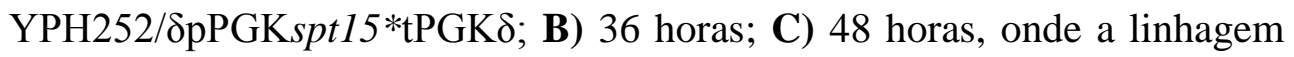
recombinante YPH252/pMA91spt15* começou a fermentar; D) 60 horas , onde a linhagem recombinante YPH252/pMA91, começou a fermentar. E) 72 horas, na qual as linhagens recombinantes YPH252/pMA91spt15* e

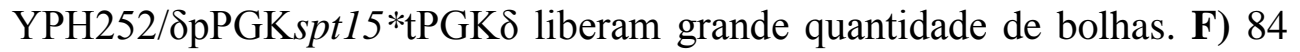
horas.

Figura 18. Curvas de crescimento em meio YPD (5\% glicose) das linhagens YPH252/pMA91spt15* (quadrado), YPH252/opPGKspt15*tPGK $\delta$ (triângulo) e YPH252/pMA91 (controle) (losângulo), cultivadas a $28{ }^{\circ} \mathrm{C}$, com aeração em frascos agitados "shaker"

Figura 19. Curvas de crescimento em meio YPD (20\% glicose) das linhagens

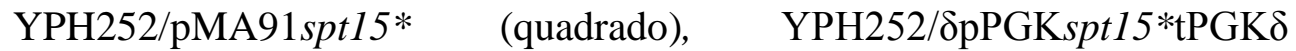
(triângulo) e YPH252/pMA91 (controle) (losângulo), cultivada a $28{ }^{\circ} \mathrm{C}$, com aeração em "shaker"

Figura 20. Peso em gramas da massa seca obtida das linhagens

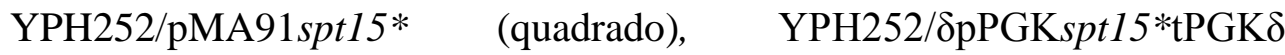
(triângulo) e YPH252/pMA91 (losângulo), em meio SD-THUAL (5\% $\begin{array}{lllllll}\text { glicose) em } & \text { estufa, } & \text { à } & 28 & { }^{\circ} \mathrm{C} & \text { por } & 80\end{array}$ horas.

Figura 21. Peso em gramas da massa seca obtido das linhagens

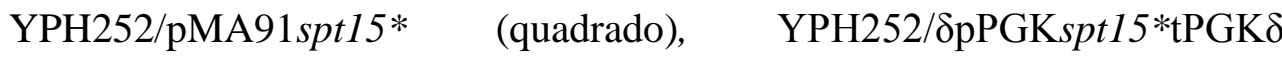
(triângulo) e YPH252/pMA91 (losângulo), em meio SD-THUAL (20\% $\begin{array}{lllllll}\text { glicose) em } & \text { estufa, } & \text { à } & 28 & { }^{\circ} \mathrm{C} & \text { por } & 80\end{array}$ horas

Figura 22. Foto do ensaio da determinação da concentração mínima inibitória (MIC) de glicose nas linhagens recombinantes, cultivadas em meio SD-THUAL, à

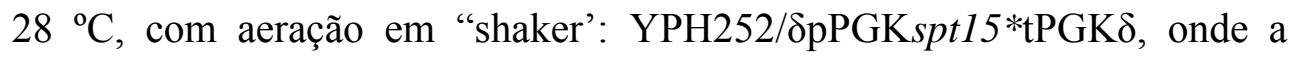
concentração mínima inibitória foi 45\% de glicose; e, B) YPH252/pMA91, onde a concentração mínima inibitória foi $30 \%$ de 
glicose

Figura 23. Análise da concentração mínima inibitória (MIC) das linhagens

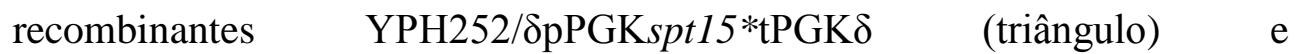
YPH252/pMA91 (losângulo), cultivo em meio SD-THUAL, à $28^{\circ} \mathrm{C}$, com agitação em "shaker", $\quad$ por 48

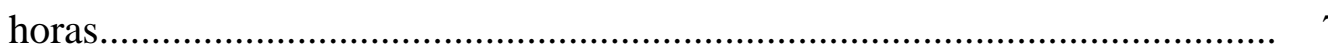

Figura 24. Gráfico do consumo de glicose do ensaio de fermentação dos clones

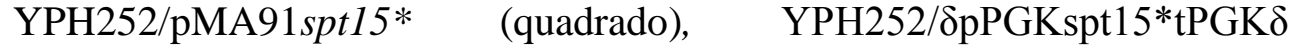
(triângulo) e YPH252/pMA91 (losângulo) em meio SD-THUAL (5\% de $\begin{array}{lllllllll}\text { glicose), } & \text { cultivados } & \text { em } & \text { estufa, } & \text { à } & 28 & { }^{\circ} \mathrm{C} & \text { por } & 80\end{array}$ horas....

Figura 25. Gráfico do consumo de glicose do ensaio de fermentação dos clones

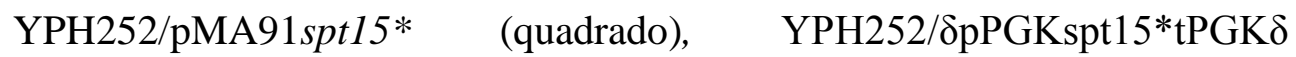
(triângulo) e YPH252/pMA91 (losângulo) em meio SD-THUAL (20\% de $\begin{array}{lllllllll}\text { glicose), cultivados em } & \text { estufa, } & \text { à } & 28 & { }^{\circ} \mathrm{C} & \text { por } & 80\end{array}$ horas

Figura 26. Gráfico de produção de etanol pelas linhagens recombinantes YPH252/pMA91spt15* (quadrado), YPH252/8pPGKspt15*tPGK $\delta$ (triângulo) e YPH252/pMA91 (losângulo) em provetas contendo $40 \mathrm{ml}$ de meio SD-THUAL (5\% de glicose), incubadas em estufa, à 28 ${ }^{\circ} \mathrm{C}$.

Figura 27. Gráfico de produção de etanol pelas linhagens recombinantes

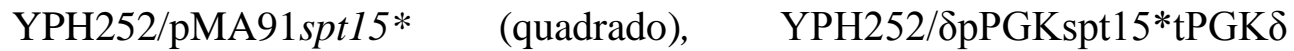
(triângulo) e YPH252/pMA91 (losângulo) em provetas contendo $40 \mathrm{ml}$ de meio SD-THUAL (20\% de glicose), incubadas em estufa, à 28 ${ }^{\circ} \mathrm{C}$. 


\section{LISTA DE TABELAS}

Tabela 1- Linhagens de bactérias Escherichia coli............................... 37

Tabela 2- Linhagens de levedura Saccharomyces cerevisiae................. 37

Tabela 3- Plasmídeos empregados neste trabalho.................................... 38

Tabela 4- Iniciadores usados para amplificação de fragmentos de

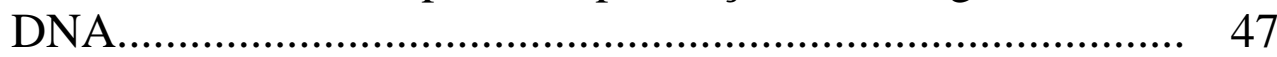

Tabela 5- Eficiência de transformação da linhagem YPH252 com o

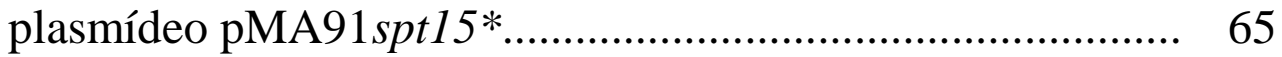

Tabela 6- Eficiência de transformação da linhagem YPH252 com o fragmento de DNA $\delta$ pPGKspt15*tPGK $\delta$............................. 65

Tabela 7- Sensibilidade dos clones YPH252/pMA91 e

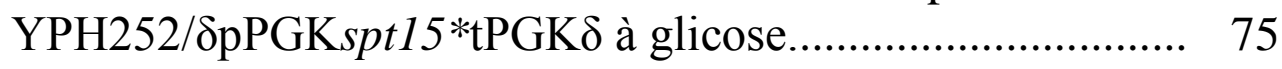




\section{ABREVIATURAS}

Abs :

Amp®:

DNA:

dNTPs:

dATPs:

dCTPs:

dGTPs:

EDTA:

HIS3:

IPTG:

LEU2:

LiAc:

LTR:

MATa:

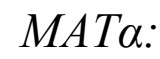

mRNA:

pb:
Absorbância

Resistência à ampicilina

Ácido desoxirribonucléico

Desoxirribonucleotídeos fosfatados

DesoxiAdenosina Trifosfatada

DesoxiCitidina Trifosfatada

DesoxiGuanosina Trifosfatada

Ácido etileno diamino tetracético

Gene selvagem codificador histidinalmidazoleglicerol-fosfatase dehidratase, enzima que catalisa o sexto passo da via de biossíntese de histidina em $S$. cerevisiae

Isopropil $\beta$-D-tiogalactopiranosídeo

Gene selvagem codificador da beta-isopropilmalato desidrogenase, enzima que catalisa o terceiro passo da via de biosíntese de leucina em $S$. cereviciae

Acetato de lítio

“Long Terminal Repeat"

locus do tipo de acasalamento a no genoma de $S$. cerevisiae

locus do tipo de acasalamento $\alpha$ no genoma de $S$. cerevisiae

Ácido ribonucléico mensageiro

Pares de bases 
PCR: $\quad$ Reação de polimerase em cadeia

PEG: $\quad$ Polietilenoglicol

PGK: $\quad$ Gene codificador da enzima 3-fosfoglicerato quinase

pPGKspt15*tPGK Cassete de expressão contendo o alelo triplo mutado spt15* sobre controle transcricional do promotor $\mathrm{e}$ terminador PGK.

$\delta$ pPGKspt15*tPGK $\delta$ Fragmento de DNA usado para trans integração, que corresponde ao casse contendo o alelo triplo mutado spt15\% sobre controie transcricional do promotor e terminador PGK, ladeado pelo elemento $\delta$ (Longa repetição terminal de Ty1)

rpm: $\quad$ Rotação por minuto

SPT15: $\quad$ Gene selvagem codificador da proteína TBP

spt15*: $\quad$ Alelo triplo mutado do gene SPT15

TBP: $\quad$ TATA-box binding proteína

TAFs: $\quad$ Fatores de transcrição

TATA-box: $\quad$ Sítio de ligação para a RNA polimerase

TRP1: Gene selvagem codificador da fosforibosilantranilato isomerase, enzima que catalisa o terceiro passo da via de biosíntese de triptofano em $S$. cerevisiae

URA3: Gene selvagem codificador da orotidina-5-fosfato descarboxilase (ODCase), enzima envolvida na síntese de novo ribonucleotídeos pirimidinicos em $S$. cerevisiae

$\mathrm{U}: \quad$ Unidades

$\lambda: \quad$ Comprimento de onda 


\section{SUMÁRIO}

1 INTRODUÇÃ O .................................................................. 22

1.1 Etanol no Brasil................................................................ 22

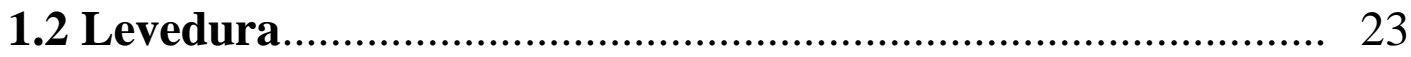

1.3 Transformação genética de Saccharomyces cerevisiae ............ 25

1.4 Transformaçãa de S. cerevisiae ............................................... 28

1.5 Transformação de $S$. cerevisiae por $\delta$ - integração.................. 29

1.6 Fatores de transcrição em Saccharomyces cerevisiae ............... 30

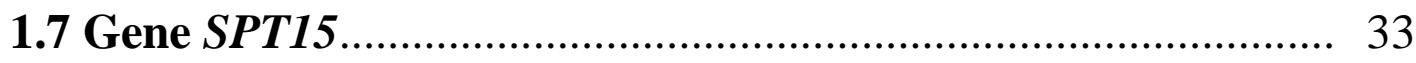

2 OBJETIVO

3 MATERIAL E MÉTODOS.................................................. 37

3.1 Linhagem de bactérias...................................................... 37

3.2 Linhagem de leveduras........................................................ 37

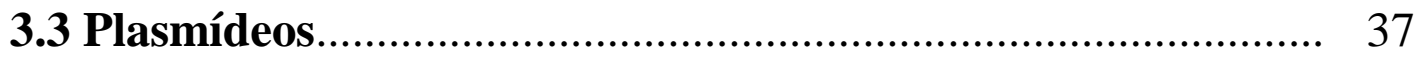

3.4 Meios de cultura para o cultivo de bactérias........................... 38

3.5 Meios de cultura para o cultivo de levedura............................ 39

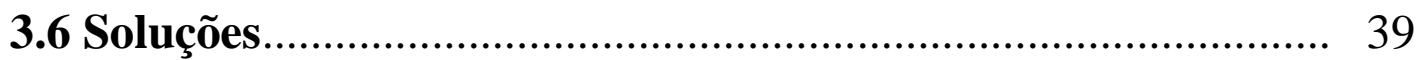

3.7 Extração e purificação de DNA plasmidial bacteriano........... 41

3.8 Tratamento de DNA plasmidial com enzimas de restrição.... 42

3.9 Análise dos fragmentos de DNA em gel de agarose................. 42

3.10 Purificação de fragmentos de DNA de gel de agarose........... 42

3.11 Desfosforilação de fragmentos de DNA................................. 42

3.12 Ligações entre fragmentos de DNA......................................... 43

3.13 Obtenção dos fragmentos de DNAs codificadores do gene

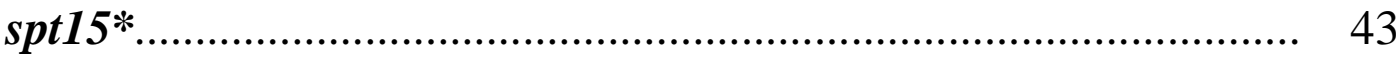

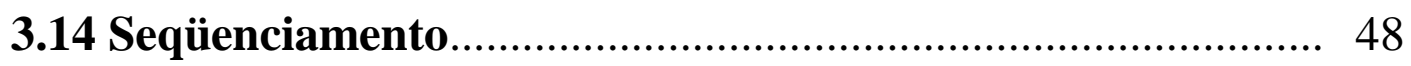

3.14.1 Seqüenciamento e obtenção do cassete de expressão de

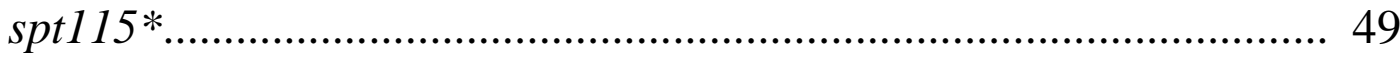


3.14.2 Seqüenciamento do fragmento final de DNA

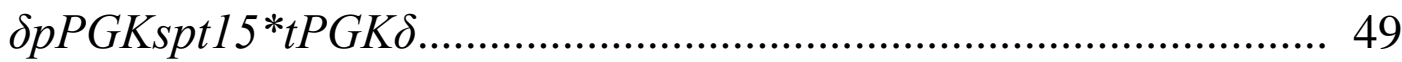

3.15 Transformação de bactéria $E$. coli........................................ 49

3.16 Transformação genética de levedura S. cerevisiae ................. 49

3.17 Extração de DNA cromossomal de levedura......................... 50

3.18 Análise qualitativa da capacidade fermentativa dos clones S. cerevisiae recombinantes obtidos............................................ 50

3.19 Dosagem do peso da massa seca do ensaio de fermentação dos clones em meio SD-THUAL (5 e $20 \%$ glicose)........................ 51

3.20 Crescimento dos clones YPH252/pMA91,

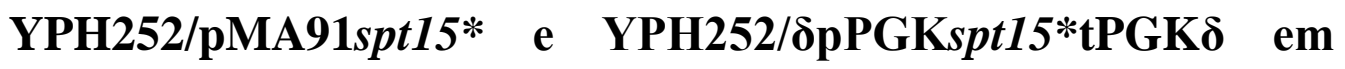

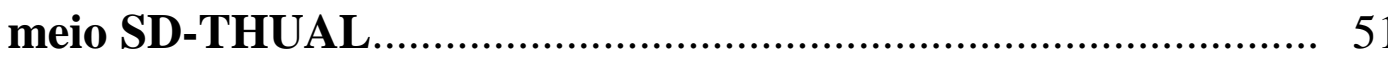

3.21 Sensibilidade do clone YPH252/סpPGKspt15*tPGKס a diferentes concentrações de glicose.

3.22 Dosagem da atividade de fermentação dos clones pela avaliação do consumo de glicose ................................................. 52

3.23 Dosagem da atividade de fermentação dos clones pela avaliação da produção de etanol.................................................... 53

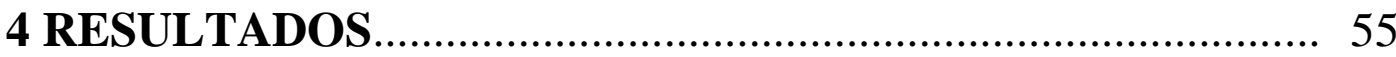

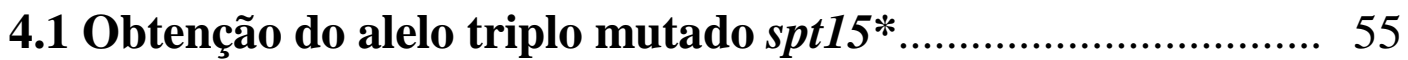

4.1.1 Obtenção do fragmento spt 15 *............................................. 55

4.1.2 Clonagem do gene spt15* no plasmídeo intermediário

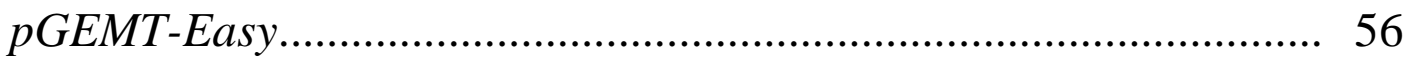

4.1.3 Análise da seqüência do alelo spt15* construído neste

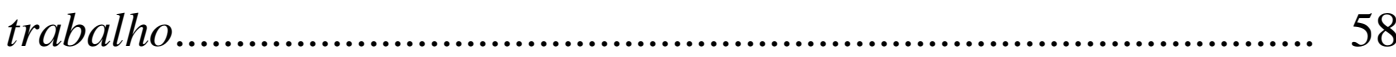

4.2 Clonagem do gene $\operatorname{spt} 15^{*}$ no plasmídeo de expressão de

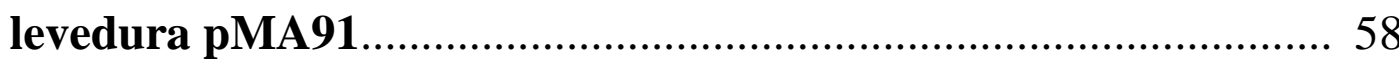

4.3 Clonagem do gene $s p t 15^{*}$ em sistema para $\delta$ - 
Transformação de levedura

4.3.1 Clonagem do cassete de expressão de spt15* no vetor pCR ${ }^{\circledR}$ 2.1-TOPO ${ }^{\circledR}$

4.3.2 Clonagem do cassete de expressão pPGKspt15*tPGK no plasmídeo pGEM-TEasy $\delta$ BamHI

4.4 Obtenção de transformantes da linhagem S. cerevisiae YPH252 com o plasmídeo pMA91spt15* e com fragmento de

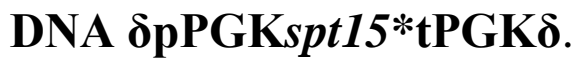

4.4.1 Transformação de YPH252 com o plasmídeo pMA91spt15*... 65

4.4.2 Transformação de YPH252 com o fragmento de DNA $\delta p P G K \operatorname{spt} 15 * t P G K \delta$.

\subsection{Caracterização dos clones transformantes}

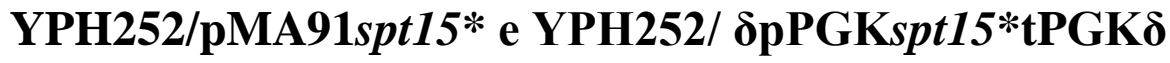

4.5.1 Análise qualitativa.

4.5.2 Análise do peso da massa seca das leveduras recombinantes

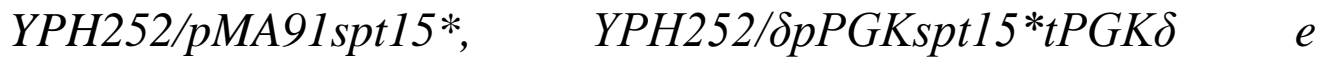
YPH252/pMA91

4.5.3 Análise da curva de crescimento das leveduras recombinantes YPH252/pMA91spt15*,

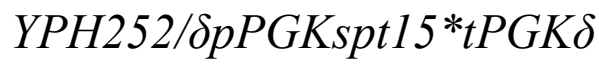
$e$ YPH252/pMA91.....

4.5.4 Análise da concentração mínima inibitória dos clones

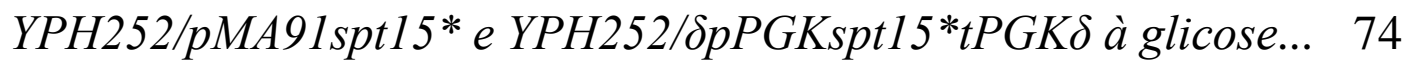
4.5.5 Análise quantitativa do consumo de glicose dos recombinantes YPH252/pMA91spt15*,

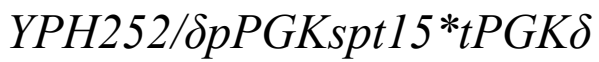
$e$ YPH252/pMA91. 76

4.5.6 Análise quantitativa da produção de etanol das linhagens recombinantes YPH252/pMA91spt15*, 


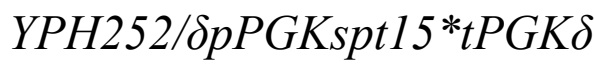

YPH252/pMA91.

4.6 Análise da seqüência do alelo SPT15 da linhagem $S$. cerevisiae industrial PE-2.

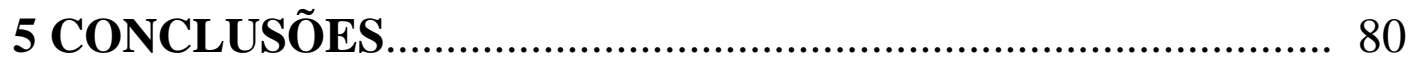

REFERÊNCIAS …........................................................ 81

ANEXO - Seqüência alinhada do gene SPT15 e do alelo triplo mutado spt15* 


\section{INTRODUÇÃO}

\subsection{Etanol no Brasil}

Atualmente, a bioenergia ainda não é uma alternativa capaz de solucionar totalmente o problema energético, mas já oferece o potencial de substituir parcialmente os combustíveis fósseis nos meios de transporte. O termo bioenergia não inclui a biomassa tradicional, isto é, aquela derivada de madeira/lenha coletada, para uso doméstico, nem a biomassa proveniente de desmatamento. Na área de bioenergia destaca-se o etanol para uso em veículos.

O Brasil é o país do mundo que reúne o maior quantitativo de vantagens comparativas para liderar a agricultura para a bioenergia. A primeira vantagem comparativa que se destaca é a perspectiva de incorporação de áreas à agricultura de energia, sem competição com a agricultura de alimentos. $O$ segundo aspecto a considerar é a possibilidade de múltiplos cultivos dentro do ano calendário. Por situarse, predominantemente, na faixa tropical e subtropical do planeta, o Brasil recebe intensa radiação solar, ao longo do ano. A energia solar é a base da produção da bioenergia e a densidade desta, por unidade de área, depende, diretamente, da quantidade de radiação solar incidente. Em decorrência de sua extensão e localização geográfica, o Brasil apresenta diversidade de clima, exuberância de biodiversidade e detém um quarto das reservas superficiais e sub-superficiais de água doce. Finalmente, o Brasil é reconhecido por haver assumido a liderança na geração e implantação de tecnologia de agricultura tropical, associada à uma pujante agroindústria, em que um dos paradigmas é justamente a agroindústria de etanol, reconhecida como a mais eficiente do mundo, em termos de tecnologia de processo e de gestão, sendo atualmente um dos maiores industrializadores e exportadores de álcool do mundo. Na safra de 2009, a produção foi de aproximadamente 19 bilhões de litros de etanol, sendo o segundo maior produtor mundial perdendo apenas para os Estados Unidos. Estes atributos foram conquistados na década de 70 , pela intervenção do poder público a partir da criação do Próalcool em 1975, quando o mercado nacional passou a utilizar o álcool em veículos automotivos.

O Proálcool foi um programa bem-sucedido de substituição em larga escala dos derivados do petróleo. Foi desenvolvido para evitar o aumento das dependências externas de divisas quando dos choques de preço do petróleo. O Programa Nacional do Álcool ou Proálcool foi criado em 14 de novembro de 1975 pelo decreto $\mathrm{n}^{\mathrm{o}} 76.593$, com 
o objetivo de estimular a produção do álcool, visando o atendimento das necessidades do mercado interno e externo e da política de combustíveis automotivos.

Atualmente, a maioria do etanol produzido é usado como biocombustível, representando mais de $40 \%$ do total de gasolina consumida no país. (Farrell et al., 2006; Hill et al., 2006; Goldemberg, 2007; Basso et al., 2008).

O uso do etanol como fonte de energia pode ser considerado como neutro do ponto de vista do balanço de carbono, pois a geração de gás carbônico, em qualquer etapa do ciclo de produção, seja através da queima, da fermentação e da combustão nos veículos automotores, é absorvida pela lavoura de cana-de-açúcar durante o seu crescimento na safra seguinte. Assim, a produção industrial de álcool combustível a partir da biomassa se destaca como uma excelente estratégia tanto do ponto de vista econômico quanto energético e ambiental. A descoberta de fontes alternativas de energia tem despertado o interesse de cientistas, governos e da população em geral, em virtude tanto da já prevista escassez de petróleo nas próximas décadas, como também pelo aumento da poluição ambiental ocasionada pelo uso de combustíveis fósseis. (Farrell et al., 2006; Hill et al., 2006; Goldemberg, 2007).

\subsection{Levedura}

As leveduras fazem parte de um grupo de microrganismos eucariontes unicelulares amplamente distribuídas na natureza. Elas têm sido utilizadas pelo homem há milhares de anos, em processos de fermentação alcoólica e preparo de pães, causando um grande impacto na produção de alimentos e influenciando no desenvolvimento socioeconômico da humanidade. Embora as leveduras sempre tenham tido importantes papéis nesses processos, o conhecimento da participação de organismos vivos na fermentação somente foi demonstrado em 1876, por Louis Pasteur. Posteriormente, Hansen isolou leveduras de processos de fermentação e propagou culturas puras. Esse fato propiciou grande desenvolvimento dos processos fermentativos e, também, inúmeros trabalhos visando à obtenção de novas linhagens de levedura que foram adequadas para cada processo (Hammond, 1993; Voorst et al., 2006).

Por serem organismos unicelulares, as leveduras apresentam as mesmas facilidades de manipulação e crescimento que as bactérias; porém, com uma série de vantagens adicionais, no que se refere à produção de proteínas heterólogas de origem eucarionte, como: 1) ambiente intracelular favorável à correta formação das proteínas de eucariotos; 2) mecanismos de transcrição e processamento pós-transcricional que são 
semelhantes àqueles observados em células de eucariontes superiores; 3) tradução e capacidade de processar modificações pós-traducionais para produção de proteínas heterólogas, como: glicosilação, acilação e fosforilação (Miyamoto et al., 1985; Kukuruzinska et al., 1987; Hammond et al., 1993; Kurtzman, 1994; Mellor et al, 1998; Walker, 1998) que contribuem para a manutenção da integridade estrutural, solubilidade, atividade biológica e localização celular das proteínas. Além disso, as leveduras possuem capacidade de secreção eficiente, o que facilita a separação dos produtos recombinantes a partir do meio de cultura.

Dentre as várias leveduras, Saccharomyces cerevisiae é a mais estudada e empregada em processos industriais, como, produção de alimentos, pães, extrato de levedura, suplementos alimentares para ração animal, aroma e sabor de alimentos; bebidas (cerveja, vinho, cachaça, bebidas destiladas em geral); produção de álcool combustível, etc. Com o advento da tecnologia do DNA recombinante, tanto a levedura S. cerevisiae como outras leveduras ganharam ainda mais importância biotecnológica devido aos seus potenciais de produção de várias proteínas heterólogas (Walker, 1998). Ainda, S. cerevisiae é reconhecida pelo FDA americano ("Food and Drug Administration Department USA") como um organismo seguro, "GRAS" ("Generally Recognized As Safe"), para ser empregado como suplemento alimentar ou alimento para humanos e animais, não oferecendo riscos de contaminação por substâncias tóxicas ou alergênicas normalmente presentes em bactérias (Romanos et al., 1992).

Inúmeros estudos foram realizados e hoje $S$. cerevisiae é o eucarioto que tem a genética e fisiologia melhor estudadas, tendo sido concluído, em abril de 1996, o seqüenciamento completo do seu genoma que contém 12 milhões de bases, distribuídas em 16 cromossomos lineares de tamanho variando entre 250 e $2.000 \mathrm{~Kb}$. O mapa físico das seqüências do DNA e das seqüências das proteínas foi depositado em bancos de dados públicos (Goffeau et al., 1996, 1997).

Atualmente, é de grande importância o conhecimento da seqüência completa do genoma de $S$. cerevisiae, fato este que permitiu abrir a perspectiva da exploração da genética genômica dessa levedura. Esse tipo de abordagem permitiu a constatação e comprovação de que, na linhagem selvagem S288C de $S$. cerevisiae, os retrotransposons da família Ty1 são os mais abundantes (Goffeau et al., 1996), e tal fato vai de encontro com o conhecimento estabelecido de que também Ty1 são os retrotransposons mais comuns presentes nas várias linhagens de $S$. cerevisiae de coleções de cultura de laboratório. Embora haja relatos de que algumas linhagens $S$. 
cerevisiae selvagens tenham poucas ou nenhuma cópia de elementos Ty1 e tenham cerca de 10 a 15 cópias de elementos Ty2, esse fato merece ser mais bem estudado, pois o número de cópias de elemento Ty1 das linhagens de laboratório havia sido inicialmente, subestimado, já que se pensava que havia apenas de 30 a 35 cópias por genoma (Boeker e Sandmeyer, 1991). Hoje, após os conhecimentos derivados da análise genômica, sabe-se que os elementos Ty1 estão representados no genoma de $S$. cerevisiae em um número muito superior de cópias. Quando foi obtido o conhecimento da sequiência completa do material genético de $S$. cerevisiae, verificou-se que, no genoma haplóide da linhagem S288C, os elementos Ty1 estão presentes em 217 cópias, das quais 32 são seqüências completas (Goffeau et al., 1996; Kim et al., 1998; Plant et al., 2000; Legras e Karst, 2003).

A partir da primeira publicação mostrando a expressão de um gene heterólogo em S. cerevisiae, esse microrganismo vem sendo largamente empregado como sistema hospedeiro (Romanos et al., 1992). A extensão e diversidade de produtos expressos nesse microrganismo são significativas, variando desde simples enzimas a hormônios, fatores de crescimento, proteínas sanguíneas ou estruturas complexas como anticorpos. Nas indústrias que empregam fermentação, tais como cervejeira, de produção de bebidas destiladas, etanol combustível ou panificação, os esforços têm sido realizados no sentido de introduzir genes heterólogos codificadores de proteínas com atividades enzimáticas que possibilitem o melhoramento da eficiência e/ou capacidade do processo.

\subsection{Transformação genética de Saccharomyces cerevisiae}

O termo transformação genética tem sido usado para descrever a entrada de fragmentos de DNA no interior de células procarióticas e eucarióticas, conseqüentemente, acarretando mudanças em seus fenótipos (Gietz e Woods, 2001). O sucesso da primeira transformação genética de $S$. cerevisiae, reportada a mais de 30 anos (Beggs, 1978; Hinnen et al., 1978), permitiu que se abrissem caminhos para a inserção de genes exógenos. Desde então, diversos métodos de transformação genética de leveduras foram descritos: esferoplastos (Burgers e Percival, 1987); células intactas utilizando sais de lítio, primeiramente foi estabelecido por Ito e colaboradores em 1983 e, subseqüentemente foi melhorado por vários autores (Gietz et al., 1995); utilizando grânulos de vidro (Costanza e Fox, 1989); eletroporação (Becker e Guarente, 1991). 
$\mathrm{Na}$ tentativa de entender o processo, alguns estudos sugerem que o DNA pode se ligar à superfície da célula de levedura (Gietz et al., 1995), e que fatores que facilitam a ligação do DNA à superfície da célula aumentam a eficiência da transformação (Zheng et al., 2005). Entretanto, a ligação e a adsorção forte do DNA à superfície da célula resultariam em uma redução da eficiência da transformação (Gietz et al., 1995). A permeabilidade crescente da parede da levedura ao DNA também aumentaria a eficiência da transformação (Meilhoc et al., 1990).

Para a transformação genética de $S$. cerevisiae podemos encontrar plasmídeos com características variadas, que podem ser classificados da seguinte forma: YIp, YEp, YRp (Botstein e Davis, 1982; Ausubel et al., 1992; Griffith et al., 1993):

- Plasmideos integrativos ("Yeast Integrative plasmids" - YIp): estes plasmídeos não possuem origem de replicação de levedura e, portanto, não se replicam autonomamente dentro da célula. São mantidos na levedura, somente após a integração em seu cromossomo, o que ocorre em uma única ou poucas cópias por célula, que se mantém na descendência da célula originalmente transformada. A eficiência de transformação destes plasmídeos é muito baixa, resultando em 1 a 10 transformantes/ $\mu \mathrm{g}$ de DNA plasmidial. A freqüência de perda destes plasmídeos pela célula da levedura transformada é da ordem de $0,1 \%$ por geração, sendo considerado um plasmídeo muito estável (Rose e Broach, 1991; Ausubel et al., 1992).

A integração de um plasmídeo integrativo no cromossomo da levedura pode ocorrer das seguintes maneiras:

1) integração por adição: quando há um único evento de recombinação ou "crossing-over" e o plasmídeo se integra no cromossomo, ficando flanqueado por repetições diretas da região homóloga. Quando é utilizada uma grande quantidade de DNA na transformação, podem ocorrer inserções múltiplas em tandem, devido, provavelmente, a repetições dos eventos de recombinação (Romanos et al., 1992).

2) integração por substituição: quando acontecem eventos de recombinação, que levam a uma substituição de uma seqüência cromossomal pela sua correspondente sequiência homóloga presente no plasmídeo, sem haver integração do plasmídeo inteiro. Este fenômeno é interpretado como sendo resultante de um duplo "crossing-over" ou de conversão gênica (Orr-weaver et al., 1983 e Hou et al., 2009).

Para transformar a levedura, muitas vezes é utilizado um plasmídeo integrativo, previamente linearizado dentro da região que apresenta homologia ao locus cromossômico da levedura, onde se deseja fazer a integração. Foi verificado que as 
extremidades geradas pelo corte da dupla fita do plasmídeo são altamente recombinogênicas, aumentando assim a eficiência de transformação deste plasmídeo de 10 a 1000 vezes, em comparação à do plasmídeo circular intacto. Esta estratégia também é útil quando se deseja integrar um plasmídeo complexo, que possui vários genes de levedura, preferencialmente num único sítio específico do genoma (Orrweaver et al., 1983).

- Plasmídeos epissômicos ("Yeast Epissomal plasmids" - YEp): estes plasmídeos contêm a origem de replicação do plasmídeo $2 \mu \mathrm{m}$ natural de levedura $S$. cerevisiae. Transformam esta levedura com alta eficiência $\left(10^{4}\right.$ a $10^{5}$ transformantes/ $\mu \mathrm{g}$ de DNA plasmidial), mantendo-se em, aproximadamente, 30 cópias por célula. Porém, os transformantes obtidos com estes plasmídeos são menos estáveis que aqueles obtidos com plasmídeos integrativos, ocorrendo perda mitótica da ordem de $1 \%$ por geração em meio não seletivo (Rose e Broach, 1991; Ausubel et al., 1992).

Quando o gene defectivo para a biossíntese de leucina (d-LEU2) é usado como marcador de seleção dos transformantes obtidos com plasmídeos epissômicos, estes permanecem na levedura em um alto número de cópias por célula (100 a 200 cópias), de forma a compensar, presumivelmente, a baixa expressão do gene d-LEU2.

- Plasmídeos replicativos ("Yeast Replicative plasmids" - YRp): estes plasmídeos replicam-se autonomamente na célula de levedura, graças a presença de fragmentos de DNA cromossomais denominados ARS (sequiências de replicação autônoma), que funcionam como origem de replicação. A eficiência de transformação destes plasmídeos é da ordem de $10^{3}$ a $10^{4}$ transformantes/ $\mu \mathrm{g}$ de DNA plasmidial e estão presentes de 1 a 20 cópias por célula. Os transformantes de levedura obtidos com estes plasmídeos são extremamente instáveis, ao longo das divisões mitóticas e meióticas, devido a sua ineficiência de transmissão as células filhas. Estes transformantes, quando cultivados em meio completo, apresentam uma perda de plasmídeo maior que $1 \%$ por geração e, mesmo em meio mínimo, condição onde lhe é imposta elevada pressão seletiva, o plasmídeo é perdido em alta frequiência (Botstein e Davis, 1982; Ausubel et al., 1992; Romanos et al., 1992; Miller e Kowalski, 1993).

Para a inserção de genes heterólogos na célula da $S$. cerevisiae foram desenvolvidos diferentes vetores de transformação genética. Estes vetores são chamados de bifuncionais, pois contém uma origem de replicação para E. coli e outra para S. cerevisiae; marcador de seleção para bactérias, como genes que conferem resistência a antibióticos; e marcador de seleção para levedura como: gene LEU2, 
URA3, TRP1 e HIS3, que promovem a complementação de uma mutação auxotrófica presente na linhagem de $S$. cerevisiae hospedeira, permitindo a seleção (por complementação gênica) das células de levedura transformadas em meio carente do aminoácido ou da base nitrogenada em questão. Também é possível selecionar transformantes de leveduras que tenham recebido vetores de transformação contendo genes que conferem resistência a antibióticos de $4^{\circ}$ geração como higromicina ou geneticina (G418) (Romanos et al., 1992; Hadfield et al., 1993; Kim et al., 2001; Sambrook e Russel, 2001). Em nosso laboratório, foi desenvolvido um vetor que permite a seleção dos clones transformantes de linhagens selvagens $S$. cerevisiae pela aquisição da resistência a canavanina (Camargo 1994 e Camargo 2000).

Por outro lado, a co-transformação permite a introdução de informações genéticas na célula de levedura hospedeira, empregando-se um vetor sem marca de seleção. Por essa estratégia, a levedura é transformada, simultaneamente, com dois ou mais plasmídeos, um deles levando um marcador de seleção e o outro carregando o gene de interesse (Prado e Aguilera, 1994). Assim, os co-transformantes, células portadoras do gene de interesse (transgênicas) sem qualquer marcador de seleção positiva podem ser selecionados. As sequiências de DNA, a serem introduzidas na célula hospedeira, podem ser oligonucleotídeos (Yamamoto et al., 1992), plasmídeos lineares, circulares e fragmentos de DNA obtidos por PCR (Duno et al., 1999; Rubió 2001; Guerra et al., 2006); podendo ser empregadas moléculas diferentes em uma mesma cotransformação, que podem permanecer na célula, replicando-se de maneira autônoma, integrando-se ao genoma, ou recombinando-se in vivo entre elas ou com o plasmídeo de seleção (Prado e Aguilera, 1994). Dada a versatilidade da metodologia, a cotransformação tem sido amplamente utilizada na levedura $S$. cerevisiae para a substituição de um gene pelo seu alelo mutado (Camargo 1994 e Camargo 2000)

\subsection{Transformação de $S$. cerevisiae}

Durante a transformação de células de levedura, pode acontecer do plasmídeo se integrar em regiões homólogas do DNA cromossomal. Este fenômeno sempre ocorre quando são utilizados plasmídeos integrativos, mas também pode acontecer, embora em baixa frequiência, quando se empregam plasmídeos de replicação autônoma (YRp) ou epissomais (YEp) (Rothstein, 1991).

Em 1989, Lopes et al. verificaram que o plasmídeo pMIRY2, que contém um fragmento de 4,5 Kb da seqüência do rDNA de $S$. cerevisiae, quando linearizado com as 
enzimas de restrição $S m a \mathrm{I}$ ou $H p a \mathrm{I}$, dentro da seqüência não transcrita NTS2 do rDNA, é capaz de transformar geneticamente $S$. cerevisiae, integrando-se em aproximadamente 140 cópias por célula haplóide. Em condições ótimas de cultivo, a expressão da proteína 3-fosfoglicerato quinase, resultante da clonagem do gene PGK nas células de $S$. cerevisiae transformadas, foi de $50 \%$ do total das proteínas solúveis. Em trabalhos posteriores, esta mesma equipe também demonstrou que a integração das cópias múltiplas acontece por amplificação de um pequeno número de cópias inicialmente integradas no locus do rDNA, quando é aplicada uma forte pressão de seleção, criada pela baixa expressão do gene d-LEU2 ou dos alelos defectivos de TRP1 ou URA3. (Lopes et al., 1991).

Fujii e colaboradores em 1990, com o objetivo de transformar uma linhagem de levedura industrial e obter múltiplas cópias integradas do gene da $\alpha$-aceltolactato descarboxilase (aldc) bacteriano, para o seu melhoramento na produção de cerveja, construiram o plasmídeo pIARL28 que contém o fragmento EcoRI-EcoRI de $3 \mathrm{~Kb}$ do rDNA. Neste caso, para a seleção dos transformantes, não foi utilizada a complementação pelo gene d-LEU2, mas sim a seleção direta por resistência à geneticina (G418). Após a transformação da levedura, foram obtidos clones com 27 cópias do plasmídeo completo inseridas no genoma, que se apresentavam altamente instáveis; e, clones com 10 ou 12 cópias do plasmídeo, que tinham perdido as seqüência plasmidiais sem interesse (gene de resistência ao $\mathrm{G} 418^{\mathrm{R}}$ e $l a c Z$ ) e eram mais estáveis.

\subsection{Transformação de $S$. cerevisiae por $\delta$ - integração}

Outra maneira para obter transformantes portadores de múltiplas cópias de genes integrados em nível cromossômico consiste na utilização de vetores capazes de realizar transposição, nos quais o gene de interesse está flanqueado por elementos transponíveis de $S$. cerevisiae (Ty). Estes vetores permitem que a informação genética desejada se integre aleatoriamente, de 30 a 40 vezes no genoma de cada célula, amplificando assim, a informação gênica que se deseja expressar (Boeke et al., 1985; Boeke et al., 1988; Garfinkel, 2005).

Os retrotransposons de $S$. cerevisiae têm sido estudados há mais de 20 anos. $\mathrm{O}$ primeiro retroelemento descrito foi o Ty1, que foi descoberto quando se começou a estudar as bases moleculares de uma mutação sofrida no gene SUP4 desta levedura. Esse elemento foi identificado como sendo uma sequiência repetida de localização variável no cromossomo (Cameron et al., 1979). Em S. cerevisiae podem ser 
encontradas pelo menos cinco diferentes tipos de famílias de retrotransposons, as quais têm sido bem estudadas comparativamente às suas seqüências: Ty1- Ty5. As famílias mais estudadas são Ty1 e Ty2, que compartilham de muitas características (Voytas, 1996; Plant et al., 2000).

O conhecimento da seqüência completa do material genético de $S$. cerevisiae possibilitou a constatação de que, no genoma haplóide da linhagem S288C, os elementos Ty1 estão presentes em 217 cópias, das quais 32 são completas; e, que as cópias de Ty2 estão presentes em 34 sítios, das quais 13 são elementos completos (Goffeau et al., 1996; Goffeau et al., 1997; Kim et al., 1998; Plant et al., 2000). Estes transposons são ladeados por longas sequiências terminais ("long terminal repeats" LTR), que no caso de Ty1 e Ty2, são denominados elementos $\delta$.

Os elementos $\delta$ (LTR de Ty1, que também são conservados em Ty2) são os LTR mais abundantes no genoma das linhagens da levedura $S$. cerevisiae de coleções de cultura. Estes elementos já foram usados como alvo de inserção de informações genéticas clonadas em linhagens $S$. cerevisiae haplóides de coleções de cultura (Garfinkel, 2005; Guerra et al, 2006); e de linhagens selvagens industriais (Guerra et al, 2006).

Recentemente, nosso grupo de pesquisas demonstrou que a $\delta$ - integração também pode ser empregada, com sucesso, para a transformação genética de linhagens $S$. cerevisiae selvagens industriais. O vetor que promove a $\delta$ - integração, pGEMTEasy $\delta$, não contém qualquer marcador de seleção positiva, por isto é realizada uma cotransformação juntamente com o plasmídio pAJ50 $\left(2 \mu \mathrm{m}, L E U 2, \mathrm{G} 418^{\mathrm{R}}\right)$, que permite a seleção de transformantes de linhagens de coleção de culturas por complementação gênica e, de linhagens industriais, pelo marcador de resistência a geneticina (Guerra et al. 2006).

\subsection{Fatores de transcrição de Saccharomyces cerevisiae}

Transcrição é a síntese de moléculas de RNA, usando a molécula de DNA como molde. A síntese ocorre pela união entre si dos nucleotídeos $\mathrm{A}, \mathrm{U}, \mathrm{C}$ e $\mathrm{G}$, que se alinham seguindo a ordem marcada pelos nucleotídeos complementares do DNA e usando a energia da hidrólise do ATP (Eisenmann et al., 1992).

Enquanto a RNA polimerase bacteriana precisa apenas de uma proteína acessória, um fator sigma, para reconhecer um promotor e iniciar especificamente a 
transcrição, todas as RNA polimerases eucarióticas precisam de várias proteínas conhecidas como fatores de transcrição.

Genes de organismos eucariotos são transcritos por três enzimas diferentes: RNA polimerase I, para genes que codificam RNAs ribossômicos (rRNAs); RNA polimerase III, para genes codificadores de RNA transportadores (tRNAs) e outros pequenos RNAs (sRNAs); e, RNA polimerase II, para genes que codificam RNA mensageiros (mRNAs), nos quais estão as seqüências de nucleotídeos necessárias para a montagem das proteínas pelo processo da tradução. A proteína TATA binding (TBP) é fundamental para a transcrição de todas as três RNA polimerases nucleares (Eisenmann et al., 1992).

A transcrição de RNA mensageiro (mRNA) em eucariotos é um processo altamente regulado que requer a associação seqüencial e coordenada de fatores de transcrição gerais (GTFs), co-reguladores, e da RNA polimerase II no promotor, para então formar um complexo de pré-iniciação (PIC) e dar início à transcrição. O mecanismo comum para ativação da transcrição requer a ligação das proteínas ativadoras diretamente, via interação seqüência específica, ou indiretamente, na seqüência ativadora upstream (UAS), para recrutar complexos co-ativadores incluindo

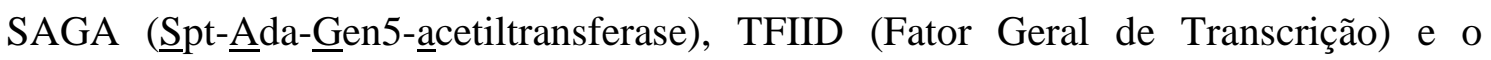
Complexo Mediador. Estes complexos co-ativadores facilitam a ligação dos fatores de transcrição gerais, tais como TBP que por fim recrutam a RNA polimerase II (Davison et al., 1983; Fire et al., 1984; Martinez et al., 1994; Hahn, 2004; Sermwittayawong e Tan., 2006; Mohibullah e Hahn., 2008).

Genes codificadores de proteínas podem ser divididos em duas partes: sequiência estrutural, também chamada de codificadora, composta pelos nucleotídeos que codificam a proteína propriamente dita; e, uma porção regulatória, chamada de promotor, na qual ocorre a maior parte do processo de regulação da expressão gênica. Existem pelo menos três características comuns à grande maioria dos promotores classe II: presença de um ponto de iniciação da transcrição (TSP), presença do TATA box; e, seqüências reconhecidas por proteínas reguladoras, chamadas ativadoras (“enhancer” ou "upstream activating sequences") ou silenciadores ("silencers" ou "upstream repressing sequences"). O TSP e TATA box podem ainda ser agrupados no que se chama de "cerne" ou núcleo do promotor, que apresenta, em geral, aproximadamente 100 pares de bases (Figura 1) (Huisinga e Pugh, 2004; Huisinga e Pugh, 2007; Baker e Grant, 2007; Hou et al., 2009). 


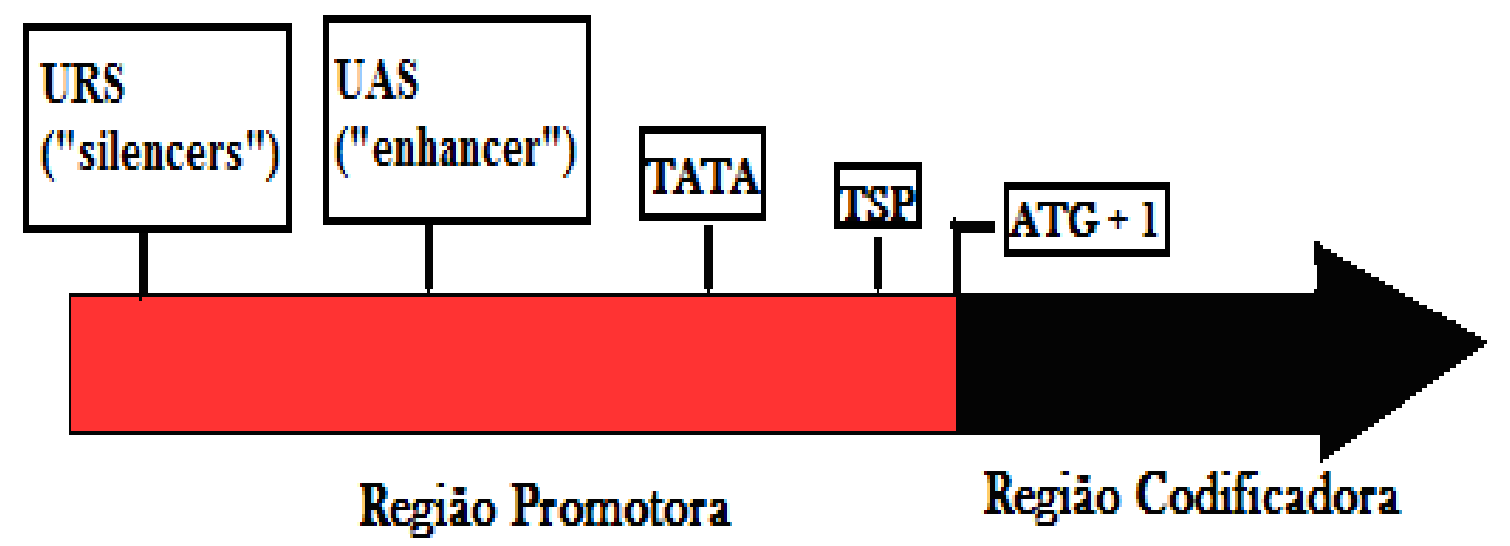

Figura 1. Esquema geral da estrutura de um gene de eucariotos, indicando os sítios encontrados nas regiões promotoras: TSP (Ponto de Inicio da Transcrição), TATA Box, e elementos regulatórios em cis (UAS e URS), além do ATG (ponto de início da transcrição), onde se inicia a transcrição.

Há mais de 30 anos, Michael Goldberg e David Hogness notaram uma seqüência rica em A-T (adenina e timina) à montante dos genes histona H2A de Drosophila melanogaster, similar em sequiência, mas não na posição da bem conhecida Pribnowbox (melhor conhecida como "seqüência -10") de promotores procarióticos. Pouco depois, seqüências similares foram identificadas à montante de muitos outros promotores eucariotos e vírus. Esta seqüência rica em A-T foram encontradas entre -25 e -30 pb, na região 5' do sítio de iniciação da síntese de mRNA. Análises mutacionais logo permitiram o entendimento de sua importância para atuação inicial da transcrição. Assim, a seqüência rica em A-T foi chamada de "Goldberg-Hogness"Box, mas agora é referida como TATA Box. Atualmente, considera-se sua seqüência consenso, com 8 pb TATA(T/A)A(T/A)(A/G) (Bjornsdottir e Myers, 2008; Tora e Timmers, 2010).

O TATA box é um sítio rico em adenina e timina que se localiza à montante do ponto de iniciação da transcrição, em geral -25 a -30 pb em eucariotos superiores; e, -40 a $-120 \mathrm{pb}$ em leveduras, ao qual se liga a proteína TATA-binding (TBP). Alguns promotores apresentam também um sítio localizado próximo ao TSP que é chamado de Iniciador (Inr), que possui importância relevante, principalmente em promotores que não possuem TATA box, pois se acredita que seja alvo de ligação de fatores de transcrição, inclusive TBP ( Martinez et al., 1994; Tora e Timmers, 2010).

RNA polimerase II não possui a habilidade de reconhecer e se ligar aos promotores, sendo necessária a formação de um complexo de pré-iniciação da transcrição para sinalizar a existência de um gene que deve ser expresso. 
O complexo de pré-iniciação da transcrição é constituído por mais de 30 polipeptídeos diferentes, entre os quais se destacam os Fatores Gerais de Transcrição (GTFs), conhecidos pela nomenclatura TFII(X) (para fatores de transcrição da classe II). Estudos pioneiros de sistemas de transcrição in vitro utilizando GTFs altamente purificados determinaram as proteínas que são fundamentais para a iniciação da transcrição, bem como para a manutenção de um nível basal de transcrição, sendo elas: TBP (componente de TFIID), TFIIA, TFIIB, TFIIE, TFIIF e TFIIH, além da RNA polimerase II (Buratowski et al., 1989; Hahn et al., 1989; Lee et al., 1992 ; Martinez et al., 1994; Yotov et al., 1998; Hahn, 2004).

\subsection{Gene SPT15}

A inserção do elemento $\delta$ (do transposon Ty) na região 5' de um gene causa seu fenótipo nulo, devido à mudança na iniciação de sua transcrição que passa a ser, com maior freqüência, a montante do elemento $\delta$ inserido, acarretando a transcrição incorreta deste gene (Eisenmann et al., 1989).

O gene supressor de Ty, denominado SPT15 de S. cerevisiae, foi originalmente identificado por seleção genética de mutações que restauraram na expressão de genes que haviam sido interrompidos por inserções no elemento $\delta$ do transposon Ty. SPT15 codifica o fator de transcrição Spt15, e está localizado no cromossomo V. Este gene é essencial para o crescimento celular, e codifica a proteína TATA-binding (TBP). Mutações neste gene, que não levam à letalidade, conferem vários fenótipos pleiotrópicos, incluindo alterações no início da transcrição de várias proteínas (Eisenmann et al., 1989; Yamaguchi et al., 2001).

A proteína TBP é um monômero de $38 \mathrm{kDa}$, considerada um dos fatores de transcrição universal mais conservado, requerida por todas as três RNAs polimerases eucarióticas. TBP possui uma estrutura em forma de "sela molecular", que apresenta motivos do tipo dedo de zinco, por meio dos quais se associa ao DNA, em sua parte côncava; composta por duas $\alpha$-hélices $(\mathrm{H})$ e cinco folha- $\beta$ preguiadas $(\mathrm{S})$ antiparalelas conectadas na ordem S1-H1-S2-S3-S4-S5-H2. TBP contém um domínio C-terminal altamente conservado ( $80 \%$ deste domínio é necessário para transcrição), dividido em duas regiões, com 90 aminoácidos cada, diretamente repetidas; e, uma região divergente N-terminal (Figura 2A). A "sela molecular" TBP, ao contrário da maioria das outras proteínas, liga-se ao sulco menor do DNA, decorrente da interação de uma seqüência específica de $8 \mathrm{pb}$, induzindo um dobramento de $80^{\circ}$ no DNA, em direção ao sulco 
maior. A parte convexa da superfície da sela é potencialmente necessária para ligação de outros fatores de transcrição ou mesmo de ativadores de transcrição gene específicos (Figura 2B) (Chasman et al., 1993; Kou et al., 2003).

$\mathbf{A}$

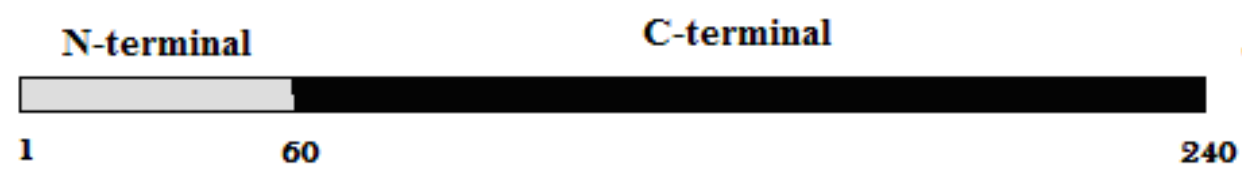

B

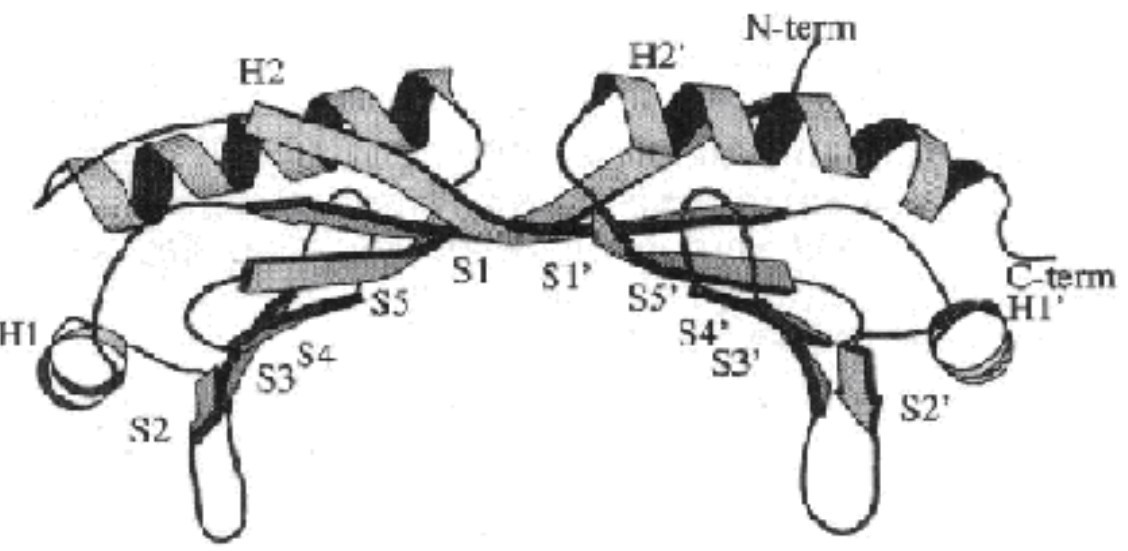

Figura 2. Proteína TATA-binding (TBP). (A) representação linear de TBP de levedura. O núcleo dominante conservado C-terminal que possui 180 aminoácidos está descrito em preto, e o domínio divergente $\mathrm{N}$-terminal, em cinza. (B) representação da estrutura conhecida como "sela molecular" de TBP, possuindo duas $\alpha$-hélices e cinco folhas- $\beta$ antiparalelas conectadas na ordem S1-H1-S2-S3-S4-S5H2 (modificado de Chasman et al., 1993).

A proteína TBP é um fator de transcrição essencial que afeta o reconhecimento do promotor e é requerido para a expressão da maioria, senão todos, os genes (Hampsey, 1998). Possui contato direto com uma grande variedade de fatores de transcrição de promotores específicos e gerais, incluindo TFIIA, TFIIB, o domínio Cterminal da subunidade grande da RNA polimerase II, fatores associados à TBP (TAFs), muitos ativadores de transcrição de gene específicos, complexo co-ativador de transcrição SAGA e reguladores de transcrição negativos (Cang et al., 1999; Kou et al., 2003; Biddick et al., 2008).

Em 2006, para avaliar a metodologia da "engenharia da maquinaria da transcrição global (gTME)" em sistemas eucarióticos, Alper et al construíram uma biblioteca genômica de seqüências mutantes obtidas por PCR mutagênica a partir do 
gene codificador do fator de transcrição de S. cerevisiae SPT15. Esta biblioteca genômica foi empregada na transformação genética da linhagem haplóide de laboratório BY4741, que já possui em seu genoma uma cópia do alelo selvagem SPT15 endógeno. Assim, cada um dos vários transformantes obtidos expressava cópia do gene SPT15 selvagem, genômica e várias cópias de uma versão mutada presentes no plasmídeo. Os transformantes foram selecionados na presença de elevados níveis de glicose (100-120 $\mathrm{g} / \mathrm{L})$ e de etanol (5-6\%). Este procedimento resultou no isolamento de um alelo SPT15 mutado, denominado spt15-300, que confere maior resistência, ao clone transformante de levedura, à glicose e ao etanol. O alelo spt15-300 contém uma tripla mutação, ou seja, resulta do efeito combinado de três mutações separadas no gene SPT15: Phe ${ }^{177}$ Ser (a serina da posição 177 foi substituída por fenilalanina), similarmente, $\mathrm{Tyr}^{195} \mathrm{His}$, e Lys ${ }^{218} \mathrm{Arg}$ (Figura 3). Os clones transformantes contendo o alelo spt15-300 apresentaram cerca de 100 genes diferentemente expressos, um grande aumento de viabilidade, quando cultivados na presença de elevadas concentrações de etanol (15\%); e, aumento do rendimento (15\%) de conversão de glicose a etanol, correspondendo a um aumento de $86 \%$ para $98 \%$ na produção de bioetanol. Além disto, estes clones apresentam fase de crescimento exponencial prolongada, o que permite superioridade em relação ao crescimento, maior produção de biomassa, nível superior de produção de etanol, e mais rápida utilização da glicose, em relação à linhagem hospedeira original (controle) (Alper et al., 2006).

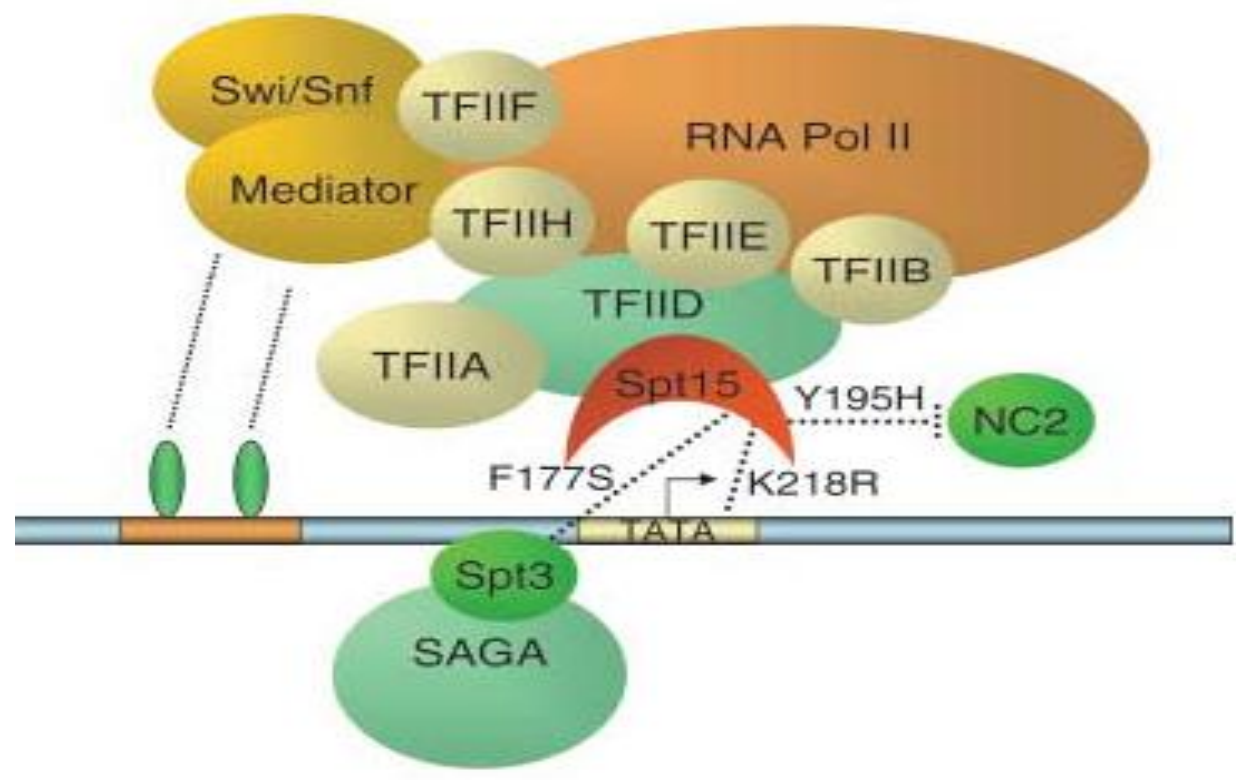

Figura 3. Esquema das três mutações (F177S, Y195H e K218R) na proteína Spt15 e seu efeito na maquinaria de transcrição global da levedura $S$. cerevisiae.

Fonte: Alper et al. (2006) 


\section{OBJETIVO}

O objetivo deste trabalho é a clonagem do gene alelo SPT15 contendo a tripla mutação Phe ${ }^{177}$ Ser, Tyr ${ }^{195}$ His, Lys ${ }^{218}$ Arg (aqui denominado spt15*) em linhagens de levedura Saccharomyces cerevisiae, visando à obtenção de novas linhagens recombinantes com capacidade aumentada de produção de etanol. 


\section{MATERIAL E MÉTODOS}

\subsection{Linhagem de Bactéria}

A bactéria utilizada no trabalho é de origem laboratorial e encontra-se estocada no banco de linhagens do laboratório de Genética Molecular de Microrganismos do Instituto de Ciências Biomédicas da USP (Tabela 1).

Tabela 1- Linhagem de bactéria Escherichia coli

\begin{tabular}{ccc}
\hline LINHAGEM & \multicolumn{1}{c}{ GENÓTIPO } & REFERENCIA \\
\hline Escherichia coli DH5a & supE44; $\Delta$ lacU 169 ( $\phi 80$ lacZ & Hanahan, 1983 \\
& $\begin{array}{ll}\Delta M 15) ; \text { hsdR17; recA1; endA; } \\
\text { gyrA96; thi-1; relA1 }\end{array}$ & \\
\hline
\end{tabular}

\subsection{Linhagens de Leveduras}

Todas as linhagens utilizadas neste trabalho se encontram estocadas no Banco de linhagens do laboratório de Genética Molecular e de Microrganismos do Instituto de ciências Biomédicas da USP (Tabela 2).

Tabela 2- Linhagens da levedura Saccharomyces cerevisiae

\begin{tabular}{|c|c|c|}
\hline LINHAGENS & $\begin{array}{c}\text { ESPÉCIE, GENÓTIPO, } \\
\text { CARACTERÍSTICAS RELEVANTES }\end{array}$ & REFERÊNCIAS \\
\hline S288C & $\begin{array}{l}\text { MAT } \alpha, \quad w t, \text { CAN1, linhagem padrão, com } \\
\text { genoma seqüienciado. }\end{array}$ & Gouffeau, 1997 \\
\hline YPH252 & $\begin{array}{l}\text { MAT } \alpha, \text { ura3-52, lys } 2-801^{\text {amber }}, \text { ade } 2-101^{\text {ochre }} \\
\operatorname{trp1}-\Delta 1, \text { his } 3-\Delta 200, \text { leu2- } \Delta 1, \text { CAN1. }\end{array}$ & $\begin{array}{l}\text { Sikorski e Hieter, } \\
1989\end{array}$ \\
\hline PE-2 & $\begin{array}{l}M A T a / M A T \alpha, w t, C A N 1, G 418^{s} \text {. Empregada na } \\
\text { produção de etanol em usinas sucroalcooleiras. }\end{array}$ & Fermentec/SP \\
\hline
\end{tabular}

OBS.: $\quad$ CAN1: fenótipo sensível a L-canavanina $(60 \mathrm{ug} / \mathrm{mL})$ G418: fenótipo sensível a geneticina $(50 \mathrm{ug} / \mathrm{mL})$ wt: linhagem selvagem, sem marcas auxotróficas, "wild type" a: linhagens gentilmente cedidas por R.S. Sikorski e P. Hieter.

\subsection{Plasmídeos}

Alguns dos plasmídeos utilizados neste trabalho já se encontram estocados na coleção do Laboratório de Genética Molecular de Microrganismos do Instituto de Ciências Biomédicas da USP (Tabela 3). 


\begin{tabular}{|c|c|c|}
\hline PLASMÍDEOS & CARACTERÍSTICAS & REFERENCIAS \\
\hline pGEM - TEasy & $\begin{array}{l}\text { Vetor comercial de clonagem em } E \text {. } \\
\text { coli, lacZ, Amp }{ }^{\circledR} \text { contendo } \\
\text { extremidades protuberantes 3'timina, } \\
\text { impedindo sua recircularização, } \\
\text { facilitando a clonagem de produtos de } \\
\text { PCR. }\end{array}$ & Promega $^{\circledR}$ \\
\hline $\mathrm{pCR}^{\circledR} 2.1-\mathrm{TOPO}^{\circledR}$ & $\begin{array}{l}\text { Vetor de clonagem comercial, lacZ, } \\
\text { Amp }{ }^{\circledR} \text { contendo extremidades } \\
\text { protuberantes 3'timina, impedindo sua } \\
\text { recircularização, facilitando a clonagem } \\
\text { de produtos de PCR. }\end{array}$ & Invitrogen ${ }^{\mathrm{TM}}$ \\
\hline pGEM - TEasy $\delta$ & $\begin{array}{l}\text { Vetor de clonagem em } S \text {. cerevisiae } \\
\text { pGEM-TEasy com adição do elemento } \\
\delta\end{array}$ & Guerra et al., 2006 \\
\hline pMA91 & $\begin{array}{l}\text { Pode ser replicado tanto em levedura } \\
\text { (marca auxotrófica LEU2) quanto em } \\
\text { bactéria (marca ampicilina). Possui o } \\
\text { promotor forte e constitutivo } P G K \text { e } \\
\text { terminador } P G K \text {. }\end{array}$ & Mellor et al., 1983 \\
\hline pJA50 & $\begin{array}{l}\text { Pode ser replicado tanto em levedura } \\
\text { (marca auxotrófica LEU2) quanto em } \\
\text { bactéria (marca ampicilina). ( } 2 \mu \mathrm{m} \text {, } \\
\text { LEU2, G428 }{ }^{\circledR} \text { ) }\end{array}$ & Jimenez e Davis, 1980 \\
\hline
\end{tabular}

\subsection{Meios de cultura para o cultivo de bactérias}

Para o cultivo da bactéria E. coli DH5a foram empregados meios LB ou SOC. Utilizou-se para o preparo dos meios de cultivo os produtos do fabricante Difco. A preparação do meio sólido foi idêntica ao do meio líquido, acrescido de $2 \%$ de agar-agar Difco. Após o preparo dos meios líquidos e sólidos, estes foram esterilizados em autoclave, a $121{ }^{\circ} \mathrm{C}, 1 \mathrm{~atm}$, por $20 \mathrm{~min}$. Quando necessário, adicionou-se, ao meio, solução de ampicilina na concentração final de $100 \mu \mathrm{g} / \mathrm{mL}$. As culturas bacterianas em meio sólido foram incubadas em estufa, a $37{ }^{\circ} \mathrm{C}$. Os cultivos em meio líquido foram realizados com aeração em "shaker", a 150 rpm, na mesma temperatura.

Meio completo (Luria Bertani) - LB:

- $1 \%$ triptona,

- $1 \%$ cloreto de sódio,

- $0,5 \%$ extrato de levedura. 
Meio de recuperação - SOC:

- $2 \%$ de triptona,

- $0,5 \%$ extrato de levedura,

- $10 \mathrm{mM}$ cloreto de magnésio,

- $10 \mathrm{mM}$ sulfato de magnésio,

- $20 \mathrm{mM}$ glicose.

\subsection{Meios de cultura para o cultivo de levedura}

Para o cultivo de levedura foram utilizados meio completo (YPD) ou meio mínimo (SD) suplementado com aminoácidos e bases nitrogenadas. Os produtos utilizados para o preparo dos meios de cultivo são do fabricante Difco, os aminoácidos e bases do fabricante Merck foram esterilizados por filtração. A preparação dos meios sólidos foi idêntica aos dos meios líquidos, acrescidos de 2\% de agar-agar Difco. Após o preparo, os meios foram esterilizados em autoclave, a $121{ }^{\circ} \mathrm{C}, 1 \mathrm{~atm}$, por $20 \mathrm{~min}$. A adição de aminoácidos e bases foi feita quando o meio estava na temperatura máxima de $45^{\circ} \mathrm{C}$. Os cultivos em meio sólido foram realizados em estufa $28{ }^{\circ} \mathrm{C}$; os cultivos em meio líquido foram realizados com aeração em "shaker" a $150 \mathrm{rpm}$, na mesma temperatura.

Meio completo - YPD:

- $1 \%$ extrato de levedura,

- $2 \%$ peptona,

- $2 \%$ glicose

Meio mínimo - SD:

- $0,67 \%$ YNB (Yeast Nitrogen Base) sem aminoácidos

- $2 \%$ glicose

Complemento para meio mínimo (SD) para levedura: Triptofano $(2 \mathrm{mg} / \mathrm{mL})$, Leucina (3 $\mathrm{mg} / \mathrm{mL})$, Lisina (3 mg/mL), Uracila $(2 \mathrm{mg} / \mathrm{mL})$, Adenina $(2 \mathrm{mg} / \mathrm{mL})$ e Histidina (2 $\mathrm{mg} / \mathrm{mL}$ ). As soluções estavam na concentração estoque $40 \mu \mathrm{g} / \mathrm{mL}$.

Meio mínimo - SD - THUAL

Refere-se ao meio mínimo SD, acrescido com a base nitrogenada Uracila e 4 aminoácidos: L-Triptofano, L-Histidina, L-Adenina e L-Lisina (concentração final no meio $40 \mu \mathrm{g} / \mathrm{mL}$ de cada aminoácido e da base nitrogenada Uracila).

\subsection{Soluções}

Para o preparo de soluções foram utilizados reagentes de pureza analítica e de procedência dos fabricantes Sigma, Merk ou Gibco-BRL. Todas as soluções foram 
preparadas conforme descrito por Sambrook e Russel, 2001, exceto quando indicado. As soluções foram esterilizadas em autoclave, a $121{ }^{\circ} \mathrm{C}, 1 \mathrm{~atm}$, por $20 \mathrm{~min}$ e, quando necessário, foram filtradas em membrana da marca Millipore de poro 0,22 $\mu \mathrm{m}$.

Soluções para extração e purificação de DNA.

\section{Solução I}

- 25 mM Tris-HCl (pH 8,0),

- $10 \mathrm{mM}$ EDTA,

- $50 \mathrm{mM}$ glicose.

Solução II

- $0,2 \mathrm{M} \mathrm{NaOH}$,

- $1 \%$ SDS.

Solução III

- $3 \mathrm{M}$ acetato de potássio (pH 4,8).

Solução SDS $10 \%$

- $10 \mathrm{~g}$ de SDS em $100 \mathrm{~mL}$ de água destilada, fervida e autoclavada.

Solução clorofórmio - álcool isoamílico

- 24 volumes de clorofórmio para 1 volume de álcool isoamílico.

Solução de acetato de sódio 5 M, pH 5,0.

Solução de acetato de potássio 3 M, pH 4,8.

Solução fenol clorofórmio

- 1 volume de fenol para 1 volume de clorofórmio.

Solução Clorofórmio - Álcool Isoamílico

- 24 volumes de clorofórmio para 1 volume de álcool isoamílico.

Solução de RNase A (Sigma)

- RNase A 10 mg em $1 \mathrm{~mL}$ de solução III. A solução foi incubada em banho-maria a $100^{\circ} \mathrm{C}$, por 10 minutos, e estocada a temperatura de $-20^{\circ} \mathrm{C}$.

Solução Tampão de eluição (TE)

- Tris-HCl 20 mM, pH 8,0; EDTA 20 mM

Agentes antimicrobianos

- Ampicilina: $100 \mu \mathrm{g} / \mathrm{mL}$ ampicilina dissolvida em água esterilizada (solução estoque). Adicionado ano meio LB na concentração final de $100 \mu \mathrm{g} / \mathrm{mL}$. 
Soluções para eletroforese de DNA em gel de agarose

Solução Tampão Tris-borato (TBE 10X)

- 0,89 mM Tris; 0,89 mM ácido bórico e 0,2 mM EDTA

- Tampão de corrida para eletroforese em gel de agarose - TBE 0.5X: Tampão TBE 10X diluído 20X.

Solução corante "Stop Mix"

- Azul de bromofenol 0,5\%; glicerol 50\%, 100 mM EDTA (pH 8,0)

Solução de brometo de etídio

- $5 \mathrm{mg}$ de brometo de etídio em $50 \mathrm{~mL}$ de água bidestilada.

\subsection{Extração e purificação de DNA plasmidial bacteriano}

A extração de plasmídeos de clones recombinantes de E.coli DH5 $\alpha$ foram realizadas a partir de um inóculo de $5 \mathrm{~mL}$ de meio $\mathrm{LB}$ contendo ampicilina (concentração final de $100 \mu \mathrm{g} / \mathrm{mL}$ ), cultivados a $37^{\circ} \mathrm{C}$, durante 16 horas, com agitação em "shaker", a $100 \mathrm{rpm}$. A cultura foi centrifugada em tubos de microcentrífuga do tipo "Eppendorf" de 1,5 mL, a 4.500 g, por 2 minutos, sendo o sobrenadante descartado e o excesso retirado com uma pipeta de ponteira fina. O sedimento foi suspenso em $300 \mu \mathrm{L}$ de Solução I, com auxílio de uma micropipeta. Em seguida, foram adicionados $300 \mu \mathrm{L}$ de solução II, e incubou-se por 5 minutos, a temperatura ambiente. Adicionou-se 300 $\mu \mathrm{L}$ de solução III, e incubou-se o tubo por 10 minutos, no gelo. Após esse tempo, o tubo foi centrifugado por 15 minutos, a $10.000 \mathrm{~g}$, a $4{ }^{\circ} \mathrm{C}$. O sobrenadante foi recuperado e transferido para outro tubo de microcentrífuga de 1,5 mL. Em seguida, adicionou-se 750 $\mu \mathrm{L}$ de solução clorofórmio-álcool isoamílico (solução 24:1). A mistura foi homogeinizada por inversão e centrifugada por 2 minutos, a $4.500 \mathrm{~g}$, a temperatura ambiente. A fase aquosa foi recuperada e a esta foram adicionados $700 \mu \mathrm{L}$ de álcool isopropílico (isopropanol). A suspensão foi misturada por inversão e incubada por 30 minutos, a temperatura ambiente. Após esse tempo, a solução foi centrifugada a 10.000 g, por 20 minutos, a $4{ }^{\circ} \mathrm{C}$. O sedimento foi lavado com etanol $70 \%$, a $4{ }^{\circ} \mathrm{C}$ e seco a vácuo durante 10 minutos. O resíduo seco foi resuspenso em $50 \mu \mathrm{L}$ de água bidestilada estéril e tratado com RNAse $(10 \mathrm{mg} / \mathrm{mL})$, por 30 minutos, a $37{ }^{\circ} \mathrm{C}$. Para análise, o material foi submetido à corrida eletroforética em gel de agarose $0,8 \%$. 


\subsection{Tratamento de DNA plasmidial com enzimas de restrição}

As digestões de DNA com enzimas de restrição foram realizadas com volumes finais entre 10, 20 e $100 \mu \mathrm{L}$, utilizando, o tampão de reação indicado pelo fabricante da enzima e as condições de incubação recomendadas. Foram utilizadas entre 1 a $2 \mathrm{U}$ de enzimas, para cada $\mu \mathrm{g}$ de DNA. Os tempos de incubação variaram entre 2 a 5 horas e, ocasionalmente, toda a noite. As enzimas de restrição utilizadas foram do fabricante Fermentas $^{\mathrm{R}}$.

\subsection{Análise dos fragmentos de DNA em gel de agarose}

As análises dos perfis de migração dos fragmentos de DNA foram realizadas em geis de agarose $0,8 \%$, submetidos a corridas eletroforéticas. Os géis de agarose $0,8 \%$ foram preparados com tampão TBE $0,5 \mathrm{X}$ e brometo de etídio (10 mg/mL).

As amostras de DNA, misturadas com a solução de tampão de amostra, foram aplicadas em gel e, em seguida, a corrida eletroforética foi realizada em tampão de corrida TBE 0,5X, conforme descrito em Sambrook e Russell (2001). Para a visualização do DNA, foi utilizado um transluminador com luz ultravioleta de $375 \mathrm{~nm}$. Para a fotodocumentação dos géis, foi utilizado o aparelho "Eagle-eye" da "Stratagene", modelo "Eagle-eye II".

\subsection{Purificação de fragmentos de DNA de gel de agarose}

Em vários casos, fragmentos de DNA foram submetidos à corrida eletroforética. A banda correspondente ao fragmento de DNA de interesse foi cortada do gel de agarose e transferida para um tubo de microcentrífuga de $2 \mathrm{~mL}$. Para purificação do fragmento de DNA de interesse, utilizou-se o "Kit Wizard ${ }^{R}$ SV Gel and PCR Clean-Up System" (Promega $^{\mathrm{R}}$ ). Foram seguidas as recomendações do fornecedor.

\subsection{Desfosforilação de fragmentos de DNA}

A retirada dos resíduos de fosfato das extremidades $5^{\prime}$ dos fragmentos de DNA foi realizada com a finalidade de evitar a religação da molécula, e, foi realizada empregando-se o tratamento com a enzima fosfatase alcalina ("Calf Intestinal Alkaline Phosphatase" - CIAP). Foram seguidas as recomendações de incubação indicadas pelo fabricante da enzima em uso (Fermentas ${ }^{\mathrm{R}}$ ). 


\subsection{Ligações entre fragmentos de DNA}

Para ligação de fragmentos de DNA foi utilizada a enzima DNA ligase do fago T4 que catalisa a ligação fosfodiéster entre a terminação 5' - fosfato e a terminação 3'hidroxi das fitas de DNA, promovendo a recircularização de plasmídeo, bem como a ligação entre fragmentos de DNA.

As concentrações de DNA (vetor/inserto) utilizadas nos sistemas de ligação variaram de acordo com o experimento. Normalmente, a quantidade de inserto foi de duas a três vezes a quantidade de vetor, em proporções de número de moléculas.

O sistema de ligação foi montado da seguinte maneira: à suspensão com os DNAs a serem ligados (vetor + inserto), foram adicionados 1/10 do volume final de tampão de ligase 10X, $1 \mu \mathrm{L}$ da enzima DNA ligase do fago T4 e água bidestilada estéril para completar o volume desejado. O volume final foi de $15 \mu \mathrm{L}$, podendo variar de $15 \mathrm{a}$ $20 \mu \mathrm{L}$. Os sistemas foram incubados a $16^{\circ} \mathrm{C}$, por $16-24$ horas e, então empregados na transformação genética de bactéria $E$. coli $\mathrm{DH} 5 \alpha$.

\subsection{Obtenção dos fragmentos de DNAs codificadores do gene spt15*}

O PCR por sobreposição (SOEING - "Gene Splicing by Overlap Extension”) é um método que permite unir fragmentos independentes obtidos por mutagênese sítio dirigidas ou a recombinação de moléculas de DNA (Heckman e Pease, 2007). Esta estratégia tem sido bastante utilizada para clonar fragmentos de tamanhos diferentes, principalmente quando se pretende construir fusões gênicas, em que a fase correta de leitura é indispensável. Ao desenhar oligonucleotídeos iniciadores para a amplificação de seqüências específicas por PCR, pequenas seqüências podem ser acrescentadas nas suas extremidades (Heckman e Pease, 2007). Essa técnica baseia-se em utilizar essas seqüências extras para a sobreposição dos fragmentos a serem clonados criando moléculas recombinantes (Figura 4).

Seguindo esta estratégia, foram desenhados oligonucleotídeos iniciadores visando à sobreposição de fragmentos (Tabela 4 e Figuras 4A e 4B).

Os oligonucleotídeos iniciadores utilizados foram sintetizados pela Sinapse ${ }^{\mathrm{R}}$. Os reagentes utilizados, assim como a enzima Taq DNA polimerase utilizada foram provenientes do fabricante Invitrogen $^{\mathrm{R}}$. Os oligonucleotídeos iniciadores para amplificação do alelo triplo mutado $\operatorname{spt} 15^{*}$ foram construídos a partir da sequiência do genoma da levedura laboratorial S288C, disponível no sítio National Center for Biotechnology Information (NCBI) ${ }^{1}$, NC 001137. As mutações sítio específicas 
Phe ${ }^{177}$ Ser (a serina da posição 177 foi substituída por fenilalanina), similarmente, $\mathrm{Tyr}^{195} \mathrm{His}$, e $\mathrm{Lys}^{218}$ Arg estão em vermelho, nos oligonucleotídeos $\mathrm{KPP} 2_{\mathrm{Rv}}$, KPP $3_{\mathrm{Fw}} \mathrm{e}$ $\mathrm{KPP} 4_{\mathrm{Rv}}$. Os oligonucleotídeos iniciadores $\mathrm{KPP} 1_{\mathrm{Fw}}$ e $\mathrm{KPP} 5_{\mathrm{Rv}}$ possuem sítios BamHI nas extremidades (Tabela 4). Em todas as manipulações foram seguidas as instruções enviadas pelos fabricantes. 


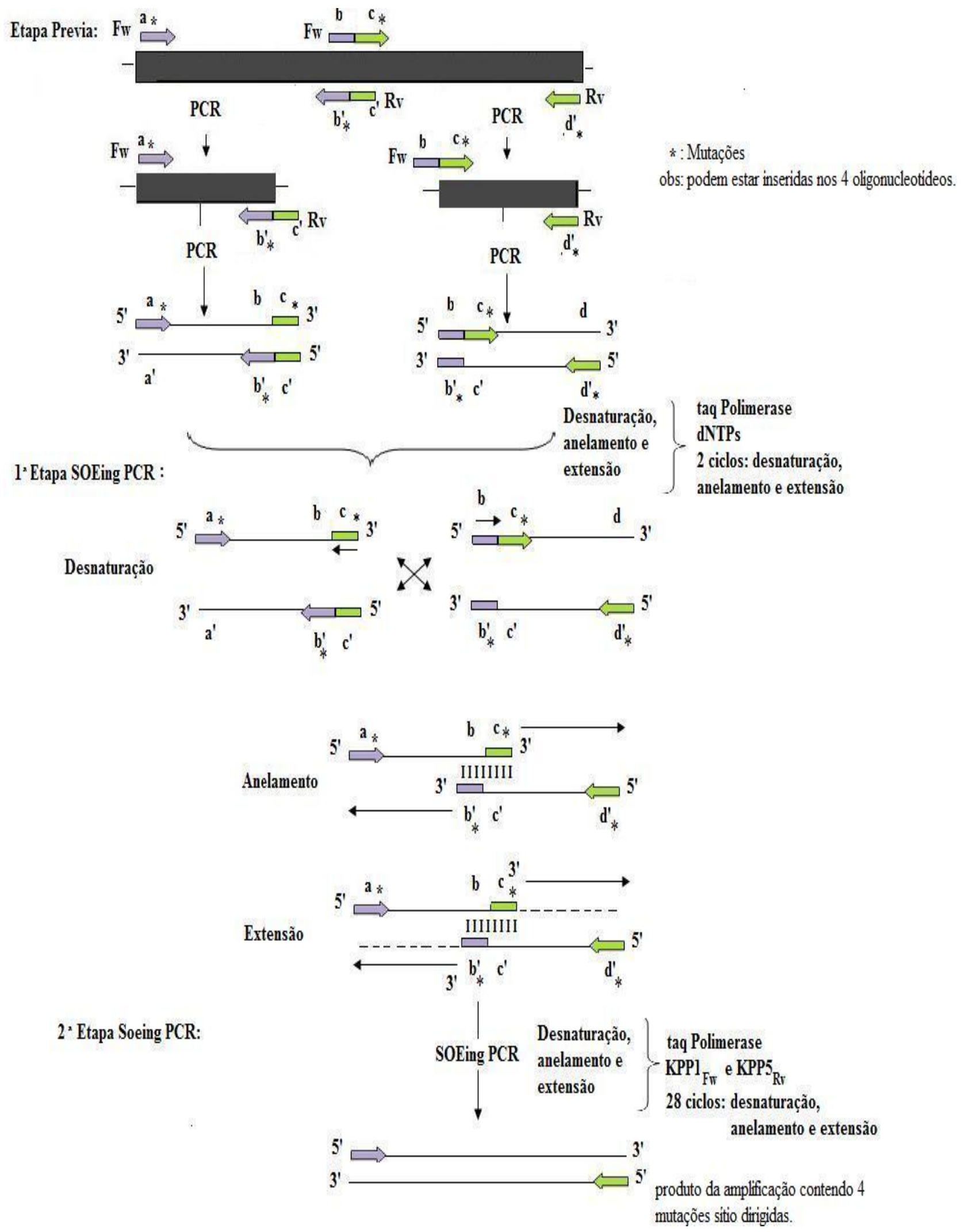

Figura 4-A. Esquema do SOEing PCR, construído a partir de Heckman e Pease, 2007. 

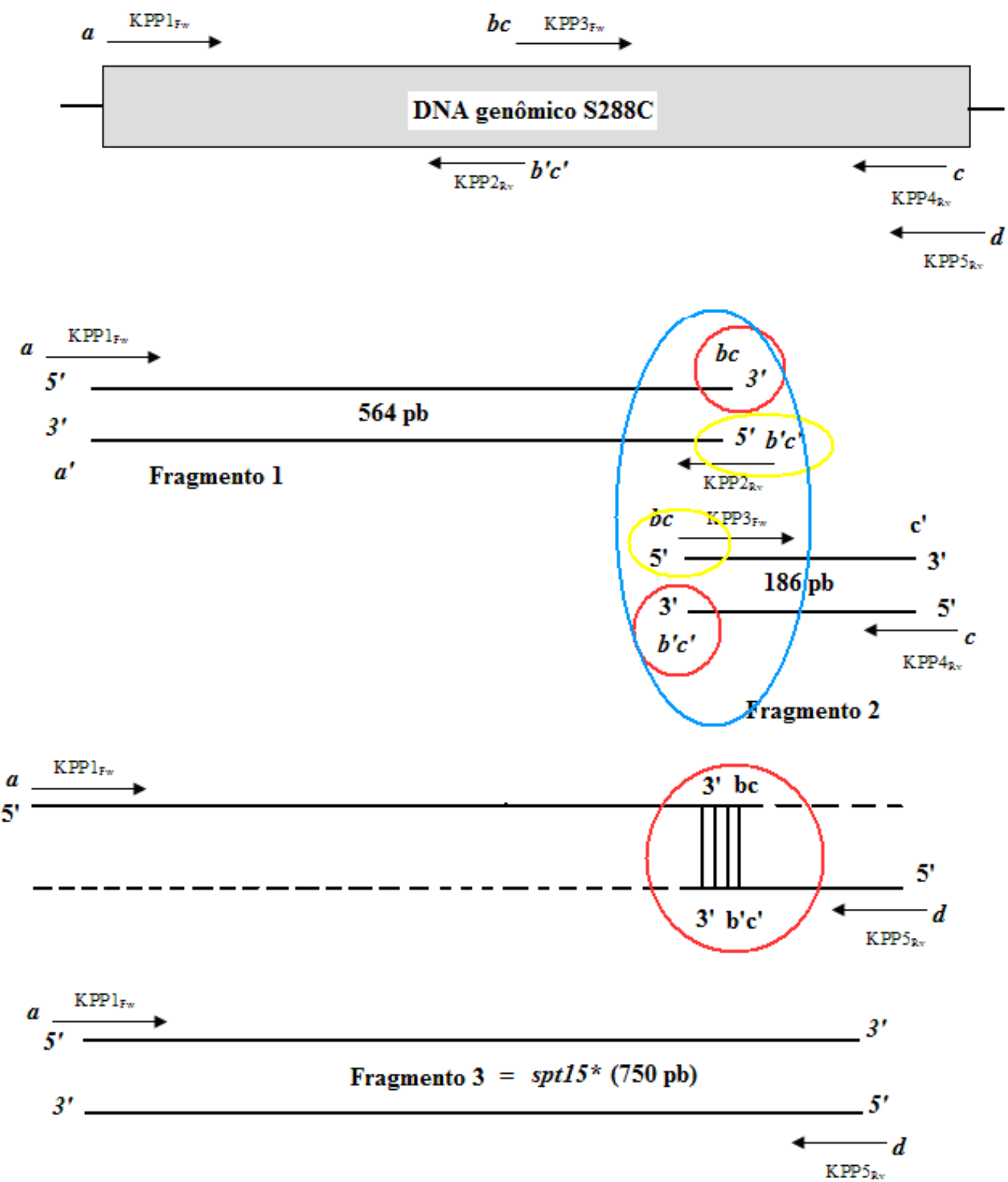

Figura 4-B. Esquema da técnica SOEing-PCR, para obtenção do gene triplo mutado spt $15^{*}$, onde o fragmento 1 foi obtido com os oligonucleotídeos: $\mathrm{KPP} 1_{\mathrm{Fw}}+\mathrm{KPP} 2_{\mathrm{Rv}}$ e possui $564 \mathrm{pb}$ e o fragmento 2 foi obtido com os oligonucleotídeos: $\mathrm{KPP} 3_{\mathrm{Fw}}+\mathrm{KPP} 4_{\mathrm{Rv}}$ e possui $186 \mathrm{pb}$. Ambos os fragmentos 1 e 2 foram usados como iniciadores e DNA molde para obtenção do fragmento 3 (spt5* que possui $750 \mathrm{pb}$ ) empregando-se os oligonucleotídeos $\mathrm{KPP} 1_{\mathrm{Fw}}$ e $\mathrm{KPP5}_{\mathrm{Rv}}$. 
A amplificação da região genômica correspondente ao alelo triplo mutado spt15* (750 pb) foi realizada empregando-se a Reação de Amplificação em Cadeia de DNA Polimerase (PCR), pelo método SOEing PCR (Figura 5). Numa etapa prévia, emprega oligonucleotídeos iniciadores de modo que resultem em amplicons cujas extremidades $3^{\prime}$ e $5^{\prime}$ contenham seqüências complementares. Os dois amplicons, contendo as seqüências complementares se anelam e, em seguida, agem como iniciadores e também como DNA molde para realizar a extensão desta área, a qual é promovida pela ação da enzima "High Fidelity" Taq DNA polimerase e dNTPs, sendo submetidos a 2 etapas da PCR. Desta maneira, é gerada uma molécula de DNA de fita dupla, contendo a fusão dos dois fragmentos de DNA. Visando obter a amplificação desta fusão, na segunda etapa foi empregado, como molde, o DNA gerado na primeira etapa de SOEing PCR.

Tabela 4- Iniciadores usados para amplificação de fragmentos de DNA

\begin{tabular}{|c|c|c|c|}
\hline INICIADOR & DNA MOLDE & SEQUENCIA 5'- 3' & FINALIDADE \\
\hline $\mathrm{KPP} 1_{\mathrm{Fw}}$ & $\mathrm{S} 288 \mathrm{C}$ & $\begin{array}{l}\text { 5'ggatccATGGCCGATGAG } \\
\text { GAACGTTTAAAGGAGTT } \\
\text { T 3' }\end{array}$ & $\begin{array}{l}\text { Amplificação spt15* } \\
\text { (fragmento } 1 \text { e } 3 \text { ) }\end{array}$ \\
\hline $\mathrm{KPP} 2_{\mathrm{Rv}}$ & S288C & 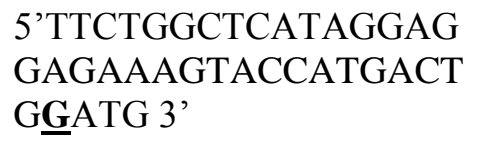 & $\begin{array}{l}\text { Amplificação spt15* } \\
\text { (fragmento 1) }\end{array}$ \\
\hline $\mathrm{KPP} 3_{\mathrm{Fw}}$ & S288C & $\begin{array}{l}\text { 5'AGCCAGAATTGTTTCC } \\
\text { TGGTTTGATCE्ATAG 3' }\end{array}$ & $\begin{array}{l}\text { Amplificação spt15* } \\
\text { (fragmento 2) }\end{array}$ \\
\hline $\mathrm{KPP} 4_{\mathrm{Rv}}$ & S288C & $\begin{array}{l}\text { 5'TCACATTTTTCTAAATT } \\
\text { CACTTAGCACAGGGTAT } \\
\text { ATAGCTTCAAAAGCTTG } \\
\text { GTAAATTTCTTCCCTTTG } \\
\text { CÉTTGCA 3' }\end{array}$ & $\begin{array}{l}\text { Amplificação spt15* } \\
\text { (fragmento 2) }\end{array}$ \\
\hline $\mathrm{KPP} 5_{\mathrm{Rv}}$ & $\mathrm{S} 288 \mathrm{C}$ & $\begin{array}{l}\text { 5'ggatcc TCACATTTTTCTA } \\
\text { AATTCACTTAGCACAGG } \\
\text { GTATATAGCTT 3' }\end{array}$ & $\begin{array}{l}\text { Amplificação spt15* } \\
\text { (fragmento 3) }\end{array}$ \\
\hline $\mathrm{PGK}_{\mathrm{Fw}}$ & pMA91spt15* & $\begin{array}{l}\text { 5'GGTCAATGCAAGAAAT } \\
\text { ACATATTTGGTCTTTTC3' }\end{array}$ & $\begin{array}{l}\text { Amplificação do cassete } \\
\text { de expressão de } \operatorname{spt} 15^{*}\end{array}$ \\
\hline $\mathrm{PGK}_{\mathrm{Rv}}$ & pMA91spt15* & $\begin{array}{l}\text { 5'CACCACCACCAGTAGA } \\
\text { GACATGGG 3' }\end{array}$ & \\
\hline$\delta_{\mathrm{Fw}}$ & pGEMTEasy $\delta$ Bamcasspt5* & $\begin{array}{l}\text { 5'TGTTGGAATAGAAATC } \\
\text { AACTA 3' }\end{array}$ & $\begin{array}{lr}\text { Amplificação } & \text { do } \\
\text { fragmento } & \text { final } \\
\delta \text { pPGKspt } 15 * \text { tPGK } \delta & \end{array}$ \\
\hline$\delta_{\mathrm{Rv}}$ & pGEMTEasy $\delta$ Bamcasspt5* & $\begin{array}{l}\text { 5'AAATGGGTGAATGT } \\
\text { TGAGATAA 3' }\end{array}$ & \\
\hline
\end{tabular}


Para amplificação dos fragmentos 1 e 2 foi empregado: um passo inicial de desnaturação a $95^{\circ} \mathrm{C}$, por 5 minutos; 30 ciclos de: desnaturação $95^{\circ} \mathrm{C}$, por 1 minuto, anelamento $63{ }^{\circ} \mathrm{C}$, por 2 minutos, e extensão $72{ }^{\circ} \mathrm{C}$, por 1 minuto; e, um passo final de 10 minutos, a $72{ }^{\circ} \mathrm{C}$, para finalizar todas as extensões incompletas.

O fragmento de DNA 1 e o fragmento de DNA 2, foram misturados e desnaturados para a obtenção do fragmento 3. A primeira etapa da reação de PCR possui 2 ciclos e as reações contém $2 \mu \mathrm{L}$ de Tampão, $1.8 \mu \mathrm{L}$ de $\mathrm{MgCl}_{2}, 3 \mu \mathrm{L}$ de dNTP, $1.5 \mu \mathrm{L}$ do fragmento $1,1.5 \mu \mathrm{L}$ do fragmento $2,10 \mu \mathrm{L}$ de água destilada estéril e $0.2 \mu \mathrm{L}$ de "High Fidelity" Taq DNA polimerase, as quais foram submetidas as condições de amplificação: 1) um passo inicial de desnaturação a $95^{\circ} \mathrm{C}$, por 5 minutos; e 2 ciclos de: desnaturação a $95{ }^{\circ} \mathrm{C}$, por 1 minuto, anelamento a $63{ }^{\circ} \mathrm{C}$, por 2 minuto, e extensão a 72 ${ }^{\circ} \mathrm{C}$, por 1 minuto; em seguida, a segunda etapa foi realizada, possuindo 28 ciclos adicionando-se as reações $1 \mu \mathrm{L}$ de Buffer, $1.5 \mu \mathrm{L}$ do oligonucleotídeo $\mathrm{KPP} 1_{\mathrm{Fw}}$ e $1.5 \mu \mathrm{L}$ do oligonucleotídeo KPP5 $5_{\mathrm{Rv}}, 5.8 \mu \mathrm{L}$ de água destilada e $0.2 \mu \mathrm{L}$ de "High Fidelity" Taq DNA polimerase, sendo reiniciada as reações de amplificação nas condições: um passo inicial de desnaturação a $95^{\circ} \mathrm{C}$, por 5 minutos; e 2) 2 ciclos de: desnaturação a $95{ }^{\circ} \mathrm{C}$, por 1 minuto, anelamento a $63{ }^{\circ} \mathrm{C}$, por 2 minuto, e extensão a $72{ }^{\circ} \mathrm{C}$, por 1 minutos. Assim, obteve-se a molécula de DNA de fita dupla denominada Fragmento 3: alelo triplo mutado $s p t 15^{*}$ de $750 \mathrm{pb}$, que possui as mutações $P$ he ${ }^{177}$ Ser (a serina da posição 177 foi substituída por fenilalanina), similarmente, $\mathrm{Tyr}^{195} \mathrm{His}$, e $\mathrm{Lys}{ }^{218} \mathrm{Arg}$, as mutações estão em negrito e sublinhado nos oligonucleotídeos $\mathrm{KPP} 2_{\mathrm{Rv}}, \mathrm{KPP} 3_{\mathrm{Fw}}$ e $\mathrm{KPP} 4_{\mathrm{Rv}}$ e os oligonucleotídeos iniciadores $\mathrm{KPP} 1_{\mathrm{Fw}}$ e $\mathrm{KPP} 5_{\mathrm{Rv}}$ contém nas extremidades sítios para a enzima BamHI (Tabela 4).

A verificação das amplificações foi feita empregando-se eletroforese em gel de agarose $0,8 \%$. Todos os produtos de PCR foram purificados a partir destes géis de agarose e posteriormente seqüenciados (Material e Métodos, itens 3.9 e 3.10).

\subsection{Seqüenciamento}

As reações de seqüenciamento foram realizadas em termociclador "MasterCycler gradient" ("Eppendorf $\mathrm{R}^{\mathrm{R}}$ ), empregando-se e o "Kit ABI PRISM DyeTM (TM elevado) Terminador Cycle Sequencing Ready Reaction /dt (Big Dye v3.1 Applied biosystems ${ }^{\mathrm{R}}$ ); seguindo as instruções do fabricante. 
O fragmento de DNA spt15* (Material e Métodos, item 3.13) foi seqüenciado, e mostrou possuir a tripla mutação sítio dirigida desejada.

\subsubsection{Seqüenciamento e obtenção do cassete de expressão de spt115*}

Para o seqüenciamento do cassete de expressão pPGKspt15*tPGK foi usado o vetor recombinante pMA91spt15* obtido por extração de DNA plasmidial do transformante da bactéria E. coli DH5 $\alpha$ /pMA91spt15* (Material e Métodos, item 3.7) e os iniciadores $\mathrm{PGK}_{\mathrm{Fw}}$ e $\mathrm{PGK}_{\mathrm{Rv}}$ sintetizados pela Sinapse ${ }^{\mathrm{R}}$ (Tabela 4).

O programa constituiu na amplificação feita por 29 ciclos de $94{ }^{\circ} \mathrm{C}$, por 2 minutos, $52^{\circ} \mathrm{C}$, por 50 segundos e $72^{\circ} \mathrm{C}$ por 1 minuto, seguido por um período final de extensão de 10 minutos, a $72{ }^{\circ} \mathrm{C}$ e foi realizado em Ciclador térmico ("DNA Enzime" modelo PTTC-200 da empresa "MJ Research").

\subsubsection{Seqüenciamento do fragmento final de DNA $\delta p P G K s p t 15 * t P G K \delta$}

Para o seqüenciamento do fragmento final $\delta$ pPGKspt15*tPGK $\delta$, foi usado o

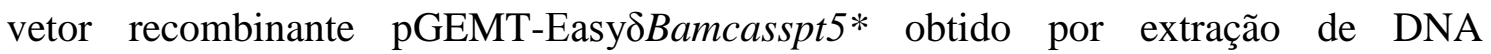
plasmidial do transformante da bactéria $E$. coli DH5 $\alpha /$ Pgemt-Easy $\delta$ Bamcasspt $15 *$ (item, 3.7) e os iniciadores $\delta_{\mathrm{Fw}}$ e $\delta_{\mathrm{Rv}}$ sintetizados pela Sinapse ${ }^{\circledR}$ (Tabela 4).

O programa constituiu na amplificação feita por 30 ciclos de $95{ }^{\circ} \mathrm{C}$ por 5 minutos, $60{ }^{\circ} \mathrm{C}$ por 1 minuto, e $72{ }^{\circ} \mathrm{C}$ por 2 minutos e 30 segundos, seguido por um período final de extensão de 10 minutos a $72{ }^{\circ} \mathrm{C}$, e foi realizado em Ciclador térmico (“DNA Enzime” modelo PTTC-200 da empresa "MJ Research").

\subsection{Transformação de bactéria $E$. coli}

Foi empregado o protocolo de transformação de E. coli por eletroporação descrito em Sambrook et al. (1989) e Sambrook e Russel (2001). As misturas de transformação foram semeadas em meio sólido LB com amplicilina (100 $\mu \mathrm{g} / \mathrm{mL})$.

\subsection{Transformação genética de levedura $S$. cerevisiae}

Para transformação das linhagens de levedura S. cerevisiae, foi empregado o método de transformação de células intactas com acetato de lítio desenvolvido por Gietz et al. (1992). As células de levedura foram cultivadas em meio líquido YPD, a $28{ }^{\circ} \mathrm{C}$, até o início da fase exponencial de crescimento (Absorbância a $600 \mathrm{~nm}$ ). Todas as vezes que este procedimento foi executado, uma alíquota de células foi transformada com uma 
preparação conhecida de plasmídeo (controle positivo); e, como controle negativo, foi empregada uma mistura de transformação sem DNA. Para a seleção dos clones transformantes, as misturas de transformação foram semeadas, sobre meio sólido SDTHUAL (Material e Métodos, item 3.5), distribuído em placas de Petri, quando os transformantes foram selecionados por complementação gênica para o fenótipo Leu ${ }^{+}$.

\subsection{Extração de DNA cromossomal de levedura}

Para a extração de DNA total de levedura, inicialmente, a linhagem desejada foi cultivada em $5 \mathrm{~mL}$ de meio líquido YPD, a $28^{\circ} \mathrm{C}$, por 16 horas. A cultura foi submetida a centrifugação por 5 minutos, a $2.000 \mathrm{~g}$, e o sobrenadante foi descartado. O sedimento foi resuspenso em $1 \mathrm{~mL}$ de tampão $\mathrm{SE}$, a suspensão foi transferida para um tubo de microcentrífuga de 1,5 mL, e centrifugada a $3.000 \mathrm{~g}$, por 30 segundos. Em seguida, o sedimento foi resuspenso em $400 \mu \mathrm{L}$ de tampão SE, foram adicionados $50 \mu \mathrm{L}$ de liticase $(20 \mathrm{mg} / \mathrm{mL})$; e, a suspensão foi incubada por 1 hora, a $37^{\circ} \mathrm{C}$. Após esse tempo, o tubo foi centrifugado a $3.000 \mathrm{~g}$, por 30 segundos, e o sobrenadante foi descartado. $\mathrm{O}$ sedimento foi, delicadamente, resuspenso em $480 \mu \mathrm{L}$ de tampão TE e foram adicionados $20 \mu \mathrm{L}$ de solução SDS $10 \%$. A mistura foi homogeneizada por inversão e incubada a $65^{\circ} \mathrm{C}$, por 30 minutos. A seguir, foram adicionados $80 \mu \mathrm{L}$ de solução acetato de potássio $5 \mathrm{M}$ e feita a incubação no gelo, por 60 minutos. Após esse período, a suspensão foi centrifugada por 15 minutos, a $4.500 \mathrm{~g}$, a $4{ }^{\circ} \mathrm{C}$. O sobrenadante foi recuperado e transferido para um tubo de microcentrífuga. Após adição de $1 \mathrm{~mL}$ de etanol absoluto, a mistura foi homogeneizada, delicadamente, por inversão, e centrifugada por 15 segundos, a 3.000 g. O sedimento foi lavado com etanol $70 \%$, a 4 ${ }^{\circ} \mathrm{C}$, e seco a vácuo, durante 10 minutos. O resíduo seco foi resuspenso em $50 \mu \mathrm{L}$ de água bidestilada estéril e tratado com RNAse $(10 \mathrm{mg} / \mathrm{mL})$, por 30 minutos, a $37^{\circ} \mathrm{C}$. Para análise, o material foi submetido à corrida eletroforética em gel de agarose $0,8 \%$.

\subsection{Análise qualitativa da capacidade fermentativa dos clones $S$. cerevisiae recombinantes obtidos}

Para se analisar a funcionalidade do alelo triplo mutado nos clones

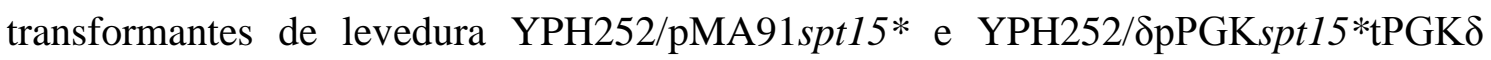
quanto às suas capacidades de utilizar a glicose presente no meio de uma forma mais rápida, estes foram comparados à linhagem YPH252/pMA91, que não possui o alelo 
triplo mutado spt $15 *$. Todos os clones foram pré-cultivados em tubos de ensaio, inicialmente, em meio líquido SD-THUAL (item 3.5) acrescido de 5\% e $20 \%$ de glicose, com aeração em "shaker" $(150 \mathrm{rpm})$ a $28^{\circ} \mathrm{C}$, por 48 horas. Este procedimento foi realizado visando se padronizar a mesma concentração de células das culturas de todos os clones. Desta pré-cultura, $5 \mu \mathrm{L}$ foram transferidos para $5 \mathrm{~mL}$ de meio SDTHUAL $5 \%$ e $20 \%$ glicose, respectivamente, em tubos de ensaio contendo tubos Durhan, e incubados, a $28{ }^{\circ} \mathrm{C}$ em estufa, e a cada 12 horas foi comparado visualmente a fermentação pela análise da presença de pequenas bolhas dentro do tubo Durhan.

\subsection{Dosagem do peso da massa seca do ensaio de fermentação dos clones em meio SD-THUAL ( 5 e $20 \%$ glicose)}

Para se medir o peso da massa seca do ensaio de fermentação, primeiramente, foi realizado uma cultura de cada um dos clones a serem analisados YPH252/pMA91,

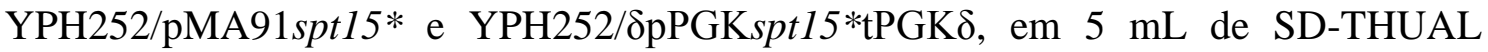
(Material e Métodos, item 3.5) acrescido de 5\% e 20\% de glicose. Após crescimento de 48 horas, a $28{ }^{\circ} \mathrm{C}$, sobre agitação em "shaker", as culturas foram centrifugadas e o sedimento resuspenso em $5 \mathrm{~mL}$ de meio SD-THUAL 5\% e $20 \%$ glicose, sendo, em seguida, inoculado em $80 \mathrm{~mL}$ de meio SD-THUAL 5\% e $20 \%$ glicose, respectivamente e, posteriormente, incubados em estufa a $28^{\circ} \mathrm{C}$, por 80 horas. A cada 8 horas foi retirada uma alíquota de $1 \mathrm{~mL}$ de cada uma das culturas e em seguida, centrifugada; o sedimento foi seco em estufa a $37^{\circ} \mathrm{C}$, por 48 horas e pesado em balança analítica.

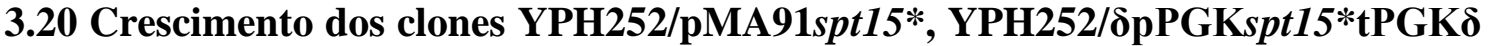 e YPH252/pMA91 em meio SD-THUAL.}

O crescimento dos clones recombinantes foi quantificado em duas diferentes concentrações de glicose, 5 e $20 \%$. Para tanto, cada clone foi cultivado em tubo de ensaio, em meio SD-THUAL, com agitação em "shaker", a $28^{\circ} \mathrm{C}$, por 120 horas e alíquotas foram retiradas a cada 12 horas para leitura da Absorbância a 600 nm.

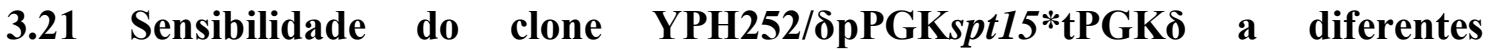 concentrações de glicose.}

Para a determinação da concentração mínima inibitória (MIC) para a glicose do

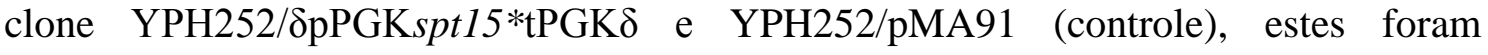


incubados em tubo de ensaio com $5 \mathrm{~mL}$ de meio SD-THUAL com concentrações de glicose variando de 5 a $45 \%$, a $28^{\circ} \mathrm{C}$, com agitação em "shaker", por 48 horas, e foram realizadas analises visualmente e, também por Absorbância a $600 \mathrm{~nm}$.

\subsection{Dosagem da atividade de fermentação dos clones pela avaliação do consumo de glicose}

A determinação quantitativa da atividade do alelo triplo mutado $\operatorname{spt} 15 *$ expressa pelos clones recombinantes de levedura, foi realizada empregando-se a dosagem da glicose consumida. Para dosar a glicose, empregou-se o método da glicose oxidase ("Kit Glucose" da BioSystems).

Foi realizado uma cultura de cada um dos clones a serem analisados

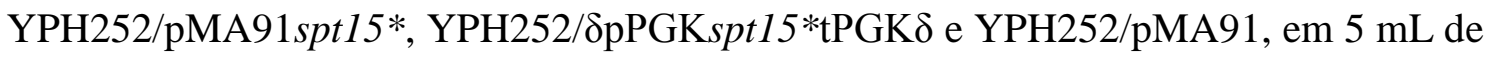
SD-THUAL (item 3.5) acrescidos de 5\% e 20\% de glicose. Após crescimento de 48 horas, a $28{ }^{\circ} \mathrm{C}$, com agitação em "shaker", as culturas foram centrifugadas e o sedimento resuspenso em $5 \mathrm{~mL}$ de meio SD-THUAL 5\% e $20 \%$ glicose e inoculou-se em 80 mL de meio SD-THUAL 5\% e 20\% glicose, respectivamente, e foram incubados em estufa a $28^{\circ} \mathrm{C}$. A cada 8 horas, durante 80 horas, retirou-se uma alíquota de $1 \mathrm{~mL}$ de cada uma das culturas e em seguida, centrifugou-se, e o sobrenadante foi usado para quantificar a dosagem de glicose consumida.

A quantificação da glicose consumida foi determinada de cada uma das culturas.

O ensaio de consumo de glicose foi realizado em tubo de ensaio:

Branco: $1 \mathrm{~mL}$ do reagente de trabalho do "kit Glucose",

Padrão: $1 \mathrm{~mL}$ do reagente de trabalho e $10 \mu \mathrm{L}$ do padrão de trabalho do "kit Glucose"

Amostra: $1 \mathrm{~mL}$ do reagente de trabalho e $10 \mu \mathrm{L}$ da amostra de cada cultura dos clones.

Foram incubados por 10 minutos à temperatura ambiente ou 5 minutos à $37{ }^{\circ} \mathrm{C}$.

Após incubação, realizou-se a leitura do ensaio em espectrofotômetro, na Absorbância de $500 \mathrm{~nm}$.

Os valores das leituras obtidas foram calculados conforme recomendações do fabricante do "kit" utilizado: 
$[$ Glicose $(\mathrm{mg} / \mathrm{dL})]=\mathrm{AbD}_{500} / \mathrm{AbP}_{500} \times 100$, onde

$\mathrm{AbD}_{500}$ : Leitura da Absorbância da amostra; e

$\mathrm{AbP}_{500}$ : Leitura da Absorbância do padrão

\subsection{Dosagem da atividade de fermentação dos clones pela avaliação da produção de etanol}

A produção de etanol foi determinada enzimaticamente em $\mathrm{g} / 100 \mathrm{~mL}$, por absorbância (420 nm) (Multiskan Ex Primary Eia V.2.1-0) utilizando as enzimas álcool oxidade (AOD, de Pichia pastoris, Sigma) e peroxidase (POD, enzima extraída da planta raiz forte, Sigma) seguindo metodologias adaptadas dos protocolos descritos por Salgado et al., 2000, Rodionov et al., 2002.

Foi realizado uma cultura de cada um dos clones a serem analisados

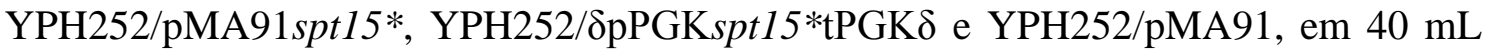
de SD-THUAL (Material e Métodos, item 3.5) 5\% glicose e 20\% glicose. Após crescimento de 48 horas, a $28{ }^{\circ} \mathrm{C}$, com agitação em "shaker", a cultura foi centrifugada e o sedimento foi resuspenso em $5 \mathrm{~mL}$ de meio SD-THUAL $5 \%$ glicose e $20 \%$ glicose, inoculou-se os $5 \mathrm{~mL}$ em $80 \mathrm{~mL}$ de meio SD-THUAL 5\% glicose e 20\%, respectivamente, e foram incubados em estufa a $28{ }^{\circ} \mathrm{C}$. A cada 8 horas, durante 80 horas, retirou-se uma alíquota de $1 \mathrm{~mL}$ de cada uma das culturas e em seguida, as alíquotas foram centrifugadas e o sobrenadante usado para quantificar a produção de etanol.

Para a determinação de etanol foi usado o reagente enzimático $(0,5 \mathrm{U}$ de AOD/ml; 4,0 U/ml de POD, 14 mM de 4-aminoantipirina e $60 \mathrm{mM}$ de fenol em Tampão fosfato de sódio $0,1 \mathrm{M} \mathrm{pH} \mathrm{7,5).} \mathrm{A} \mathrm{absorbância} \mathrm{foi} \mathrm{medida} \mathrm{a} 420 \mathrm{~nm} \mathrm{em}$ espectrofotômetro (Multiskan Ex Primary Eia V.2.1-0) e a concentração de etanol foi determinada pela correlação do valor de Absorbância apresentada para cada amostra com a equação de reta extraída de uma curva padrão construída com soluções padrão de etanol $(1,0-10 \mathrm{~g} / \mathrm{l})$

Equação de reta: $y=0,0257 x-0,0305$

A quantificação do etanol produzido foi determinada de cada uma das culturas.

O ensaio da produção de etanol foi realizado em tubo de ensaio: 
Branco: 0,2 $\mathrm{mL}$ do reagente enzimático de trabalho e $10 \mu \mathrm{L}$ de água destilada, Amostra: $0,2 \mathrm{~mL}$ do reagente enzimático de trabalho e $10 \mu \mathrm{L}$ do sobrenadante de cada amostra de cultura dos clones

Foi realizada a incubação da mistura por 1 hora, a $37^{\circ} \mathrm{C}$.

Após incubação, realizou-se a leitura do ensaio em espectrofotômetro, na Absorbância de $420 \mathrm{~nm}$. Os valores das leituras obtidas foram calculados conforme fórmula:

$[$ Etanol $(\mathrm{g} / 100 \mathrm{~mL})]=\mathrm{Ab}_{420}+0,305 / 0,257$, onde

$\left(\mathrm{Ab}_{420}\right.$ : Leitura da Absorbância da amostra à $\left.420 \mathrm{~nm}\right)$. 


\section{RESULTADOS}

Para se atingir o objetivo proposto, o alelo spt15* (SPT15 contendo a tripla mutação Phe ${ }^{177}$ Ser, Tyr ${ }^{195}$ His, Lys ${ }^{218}$ Arg (Alper et al., 2006)) foi obtido por amplificação empregando-se o método SOEing PCR, a partir do DNA total da linhagem laboratorial S288C. O alelo spt15* foi clonado no plasmídeo pMA91, ficando sua expressão regulada pelo promotor e terminador de transcrição do gene codificador da 3fosfoglicerato quinase (PGK) de S. cerevisiae. Em seguida, o cassete de expressão pPGKspt $15 *$ tPGK foi ladeado pelo elemento $\delta$ do retrotransposon Ty1 de $S$. cerevisiae.

\subsection{Obtenção do alelo triplo mutado spt $15 *$}

\subsubsection{Obtenção do fragmento spt $15 *$}

O alelo spt $15^{*}$ foi obtido por SOEing PCR, conforme descrito em Material e Métodos, item 3.13 (Figura 5) utilizando como DNA molde o DNA genômico da linhagem de levedura laboratorial S288C. Os perfis eletroforéticos dessas amplificações estão apresentados na Figura 6.

\section{A $\quad 1223456$}

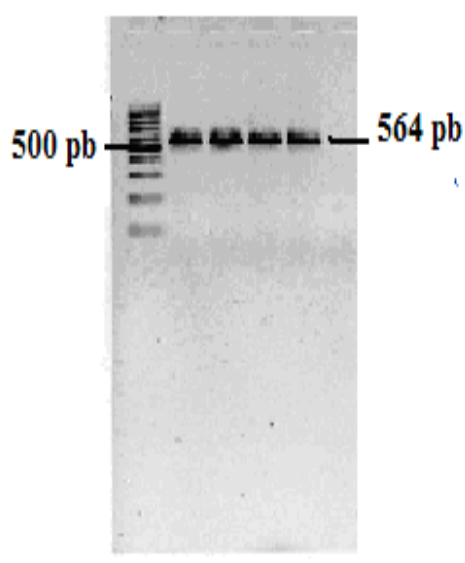

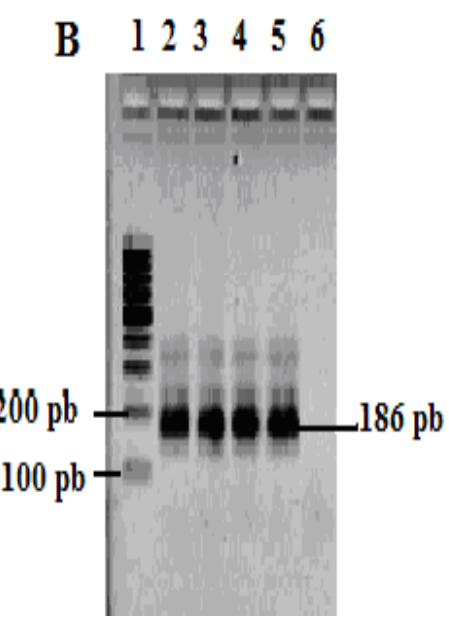

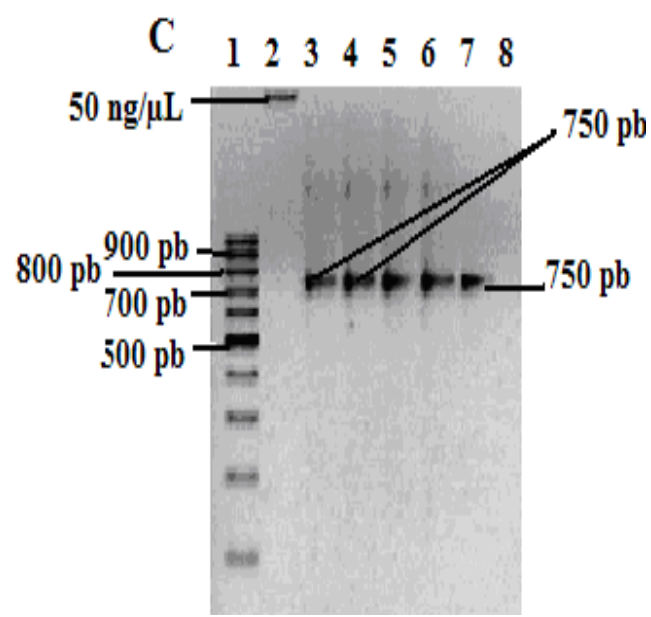

Figura 5. Fragmentos de DNA das etapas de construção de $\operatorname{spt} 15 *$ em géis de agarose $0,8 \%$ corado com brometo de etídio, submetido à eletroforese: A) 1) 100 pb DNA RULLER Fermentas (150 ng); 2 ao 5) Amplicon Fragmento 1, com 564 pb que possui a mutação codificadora Phe ${ }^{177}$ Ser (serina localizada na posição 177 substituída pela fenilalanina); 6) Controle negativo da PCR. B) 1) 100 pb DNA RULLER Fermentas (150 ng); 2 ao 5) Amplicon Fragmento 2, com $186 \mathrm{pb}$ que possui as mutações codificadoras Tyr ${ }^{195} \mathrm{His}$, Lys ${ }^{218} \mathrm{Arg}$ (histidina localizada na posição 195 foi substituída pela tirosina e a arginina localizada na posição 218 foi substituída pela lisina, respectivamente); 6) Controle negativo da PCR. C) 1) $100 \mathrm{pb}$ DNA RULLER Fermentas (150 ng); 2) Padrão de tamanho molecular Fermentas (50 ng/ $\mu \mathrm{L}) ; 3$ ao 7) Amplicon do fragmento 3 , com 750 pb que possui a tripla mutação e as extremidades dos oligonucleotídeos KPP1 e KPP5 possuem as sequências nucleotídicas reconhecidas pela enzima de restrição BamHI, onde os fragmentos 1 e 2 foram usados como DNA moldes; 8) Controle negativo da PCR. 


\subsubsection{Clonagem do gene spt15* no plasmídeo intermediário pGEMT-Easy}

O alelo spt $15^{*}$, correspondente ao fragmento de DNA $3(750 \mathrm{pb})$ obtido por SOEing PCR, foi clonado em vetor comercial, pGEM-TEasy (Vetor Systems Promega).

Para isso, a mistura de ligação do amplicon com o vetor (Material e Métodos, item 3.12) foi utilizada para a transformação de células E. coli DH5a (Material e Métodos, item 3.15) (Figura 6). Foram obtidos cerca de 68 clones Amp ${ }^{\mathrm{R}}$. Os DNAs plasmidiais de 16 colônias transformantes, foram escolhidos aleatoriamente, isolados (Material e Métodos, item 3.7), digeridos com a enzima de restrição BamHI e analisados em gel de agarose $0,8 \%$. Foram selecionados 11 plasmídeos que apresentaram perfis de restrição desejados: $750 \mathrm{pb}($ spt15*) e 3.015 pb (vetor pGEM-TEasy) (Figura 7). O plasmídeo pGEM-TEasyspt15* possui tamanho de 3.765 pb (Figura 6). 

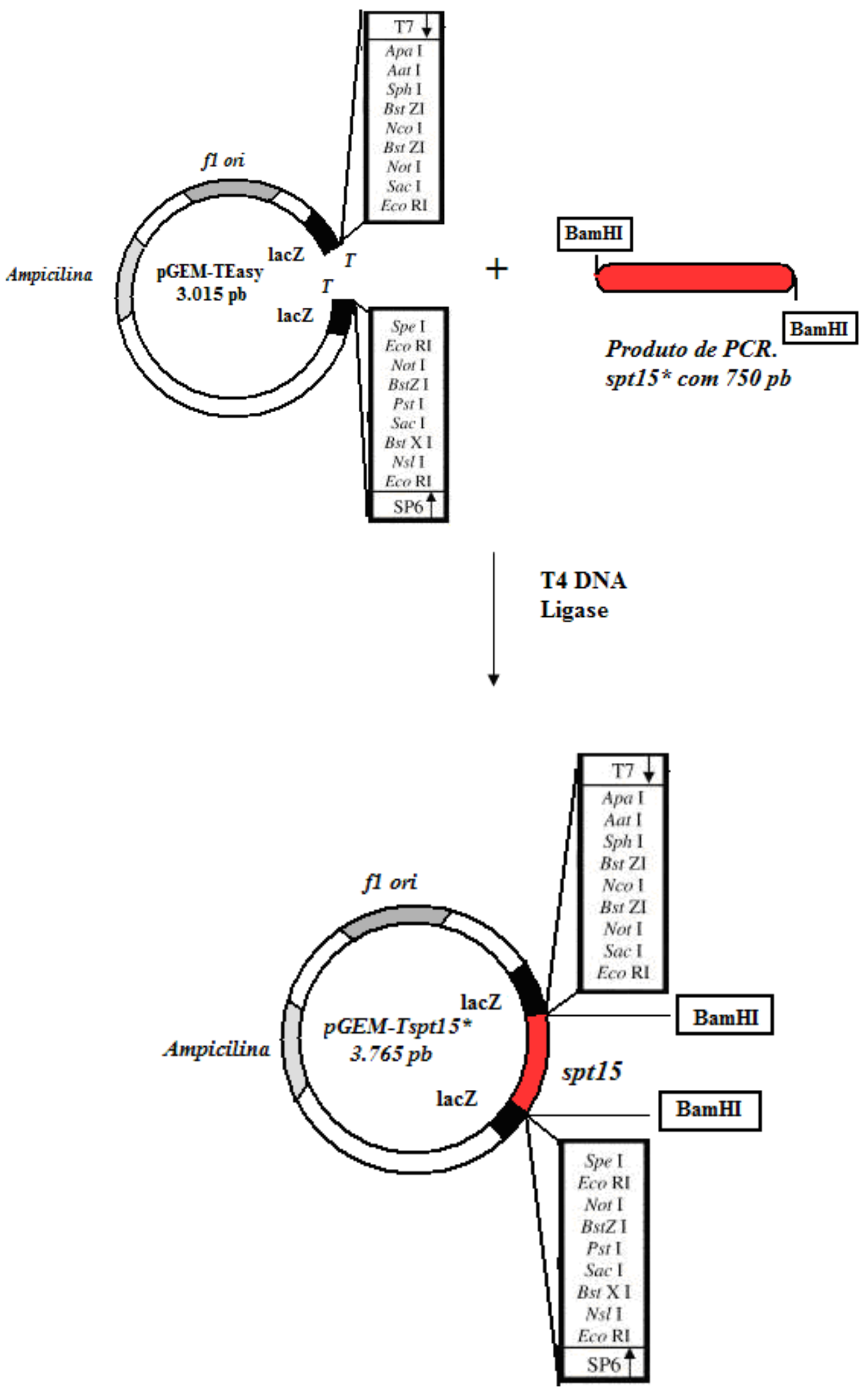

Figura 6. Esquema de clonagem do alelo SPT15 triplo mutado ( $\left.p t 15^{*}\right)$ em vetor comercial pGEMTEasy da Promega. 


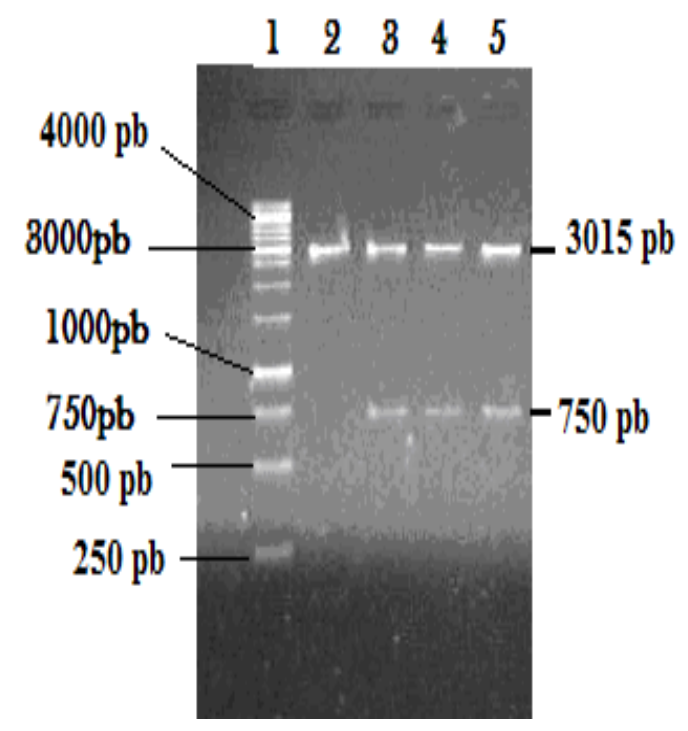

Figura 7. Perfis de migração em gel de agarose $0,8 \%$, corado com brometo de etídio e submetido à eletroforese de: 1) marcador de tamanho 1Kb DNA Ladder (Fermentas) $(50 \mu \mathrm{g})$; 2) vetor pGEM-TEasy e linearizado pela enzima de restrição BamHI; 3, 4 e 5) plasmídeo recombinante pGEM TEasyspt15*, isolado de diferentes clones digerido com a enzima de restrição BamHI, onde a banda de $750 \mathrm{pb}$ se refere ao gene $s p t 15^{*}$ e a de $3015 \mathrm{pb}$ se refere ao plasmídeo comercial pGEM-TEasy.

\subsubsection{Análise da seqüência do alelo spt15* construído neste trabalho}

Os produtos de SOEing PCR referentes ao alelo spt $15 *$ foram seqüenciados e as seqüências nucleotídicas obtidas mostraram 100\% de identidade com a seqüência do gene disponível no "National Center for Biotechnology Information” (CNBI), exceto pela tripla mutação $\mathrm{Phe}^{177} \mathrm{Ser}$, $\mathrm{Tyr}{ }^{195} \mathrm{His}$, $\mathrm{Lys}{ }^{218} \mathrm{Arg}$ (ANEXO).

\subsection{Clonagem de $\operatorname{spt15} *$ no plasmídeo de expressão de levedura pMA91}

O plasmídeo pMA91 foi empregado para a clonagem de spt15*, por ser um vetor de expressão que contém a região do promotor e do terminador de transcrição do gene da 3-fosfoglicerato quinase (PGK) de S. cerevisiae. O fragmento spt15* foi inserido no sítio BglII do plasmídeo pMA91, entre o promotor e o terminador de transcrição PGK.

O alelo $\operatorname{spt15*}$ foi obtido por digestão do plasmídeo pGEM-TEasyspt15* com a enzima de restrição BamHI. Após eluição e purificação do fragmento $\operatorname{spt} 15 *$ de 750 pb de gel de agarose 0,8\% (Figura 7) (Material e Métodos, item 3.10). Paralelamente, o plasmídeo pMA91 foi linearizado com a enzima de restrição $B g l$ II e tratado com a enzima fosfatase alcalina (Material e Métodos, item 3.11). A mistura de ligação entre o plasmídeo linearizado e o fragmento $\operatorname{spt} 15^{*}$ (Material e Métodos, item 3.12) foi 
empregada na transformação de E. coli DH5a (Material e Métodos, item 3.15) (Figura 8).

Foram obtidos 32 colônias bacterianas transformantes $\mathrm{Amp}^{\mathrm{R}}$. Os DNAs plasmidiais de 22 colônias transformantes, escolhidos ao acaso, foram extraídos (Material e Métodos, item 3.7), purificados, digeridos com a enzima de restrição BglII (Figura 9) e analisados em gel de agarose. Foram obtidos 4 plasmídeos que apresentaram os perfís de migração esperados em gel de agarose $0,8 \%$ : um fragmento de $10.250 \mathrm{pb}$ correspondente ao plasmídeo recombinante linearizado, $(9.500 \mathrm{pb}$ do plasmídeo pMA91 + $750 \mathrm{pb}$ do fragmento spt15*). Estes 4 plasmídeos foram submetidos à uma analise de restrição mais detalhada, para verificar a orientação da inserção. Para tanto, foram digeridos com as enzimas de restrição HindIII e XbaI (Figuras 8 e 9). Um deles mostrou que o fragmento $s p t 15^{*}$ havia sido inserido na orientação desejada no plasmídeo pMA91.

O fragmento de DNA pPGKspt15*tPGK foi obtido por reação de PCR (Material e Métodos, item 3.14.1), utilizando como DNA molde o DNA plasmidial do clone $E$. coli DH5a/pMA91spt15*, e os oligonucleotídeos $\mathrm{PGK}_{\mathrm{Fw}}$ e $\mathrm{PGK}_{\mathrm{Rv}}$ (Tabela 4)
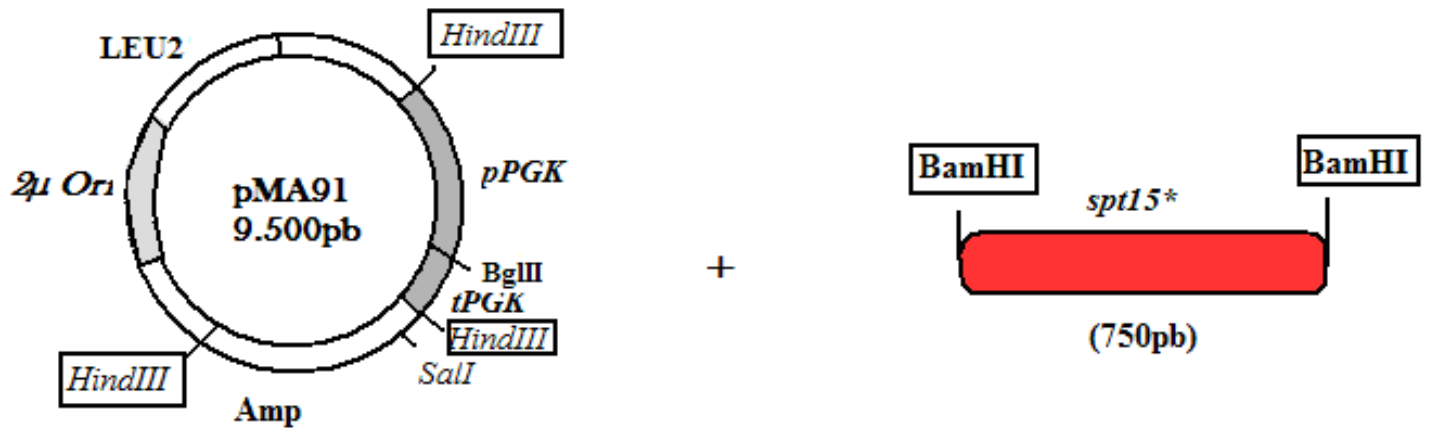

$(750 \mathrm{pb})$
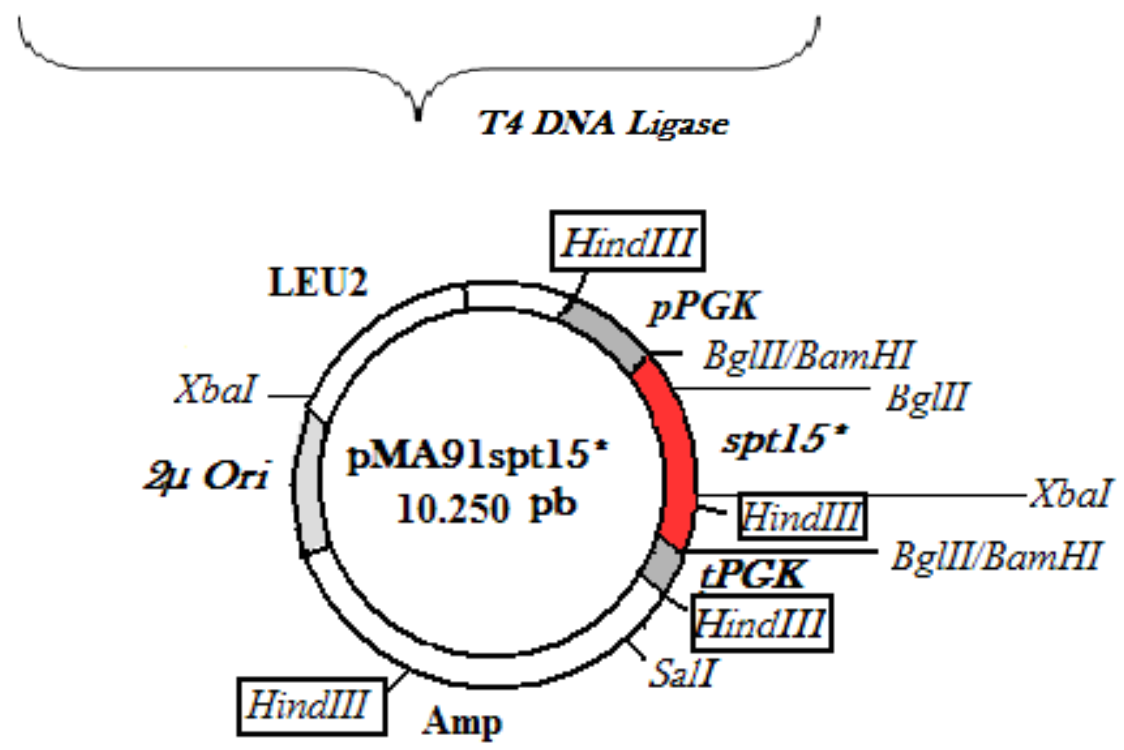

Figura 8. Esquema da clonagem do gene triplo mutado $\operatorname{spt} 15 *$ no vetor epissomal pMA91. 


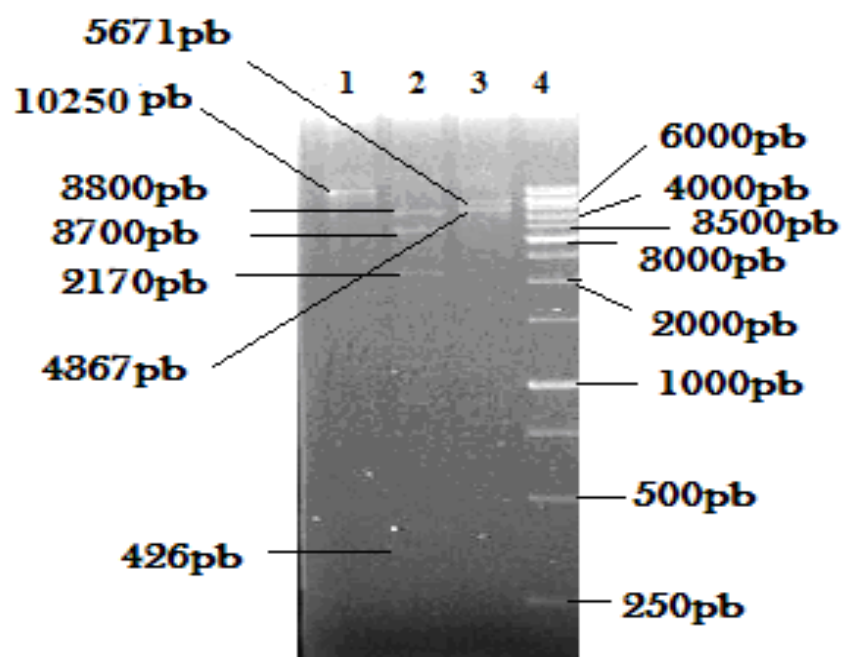

Figura 9. Perfis de migração em gel de agarose $0,8 \%$ corado com brometo de etídio e submetido à eletroforese das digestões do plasmídeo pMA91spt15* e do amplicon obtido por PCR usando como molde o DNA plasmidial extraído do clone e os primers kppl e kpp5. 1) plasmídeo recombinante pMA91spt15* digerido com a enzima de restrição BglII; 2) plasmídeo recombinante pMA91spt15* digerido com a enzima de restrição HindIII; 3) plasmídeo recombinante pMA91spt15* digerido com a enzima de restrição XbaI. 4) marcador de tamanho $1 \mathrm{~Kb}$ Ladder $\left(\right.$ Fermentas $\left.^{\mathrm{R}}\right)(50 \mu \mathrm{g})$.

\subsection{Clonagem do alelo spt $15 *$ em sistema para $\delta$ - transformação de levedura}

Para que cópias do alelo spt15* possam ser introduzidas em linhagens $S$. cerevisiae selvagens empregadas em processos industriais como os de produção de etanol, foi necessário a clonagem do cassete de expressão pPGKspt15*tPGK em um outro plasmídeo, de modo que ficasse ladeado por seqüência $\delta$ (LTR do transposon Ty1 de S. cerevisiae). Para a obtenção desta construção final, vários passos intermediários foram seguidos, conforme descrito nos próximos itens.

\subsubsection{Clonagem do cassete de expressão de spt15* no vetor $p C R^{\circledR} 2.1-T O P O^{\circledR}$}

Após eluição e purificação do cassete de expressão de spt15* (Material e Métodos, item 3.12), a mistura de ligação deste e o vetor $\mathrm{pCR}^{\circledR} 2.1-\mathrm{TOPO}^{\circledR}$ foi empregada na transformação de E. coli DH5a (Material e Métodos, item 3.15) (Figura $10)$.

Foram obtidas 23 colônias bacterianas transformantes $\mathrm{Amp}^{\mathrm{R}}$. Os DNAs plasmidiais de 15 colônias, escolhidos ao acaso, foram extraídos (Material e Métodos, item 3.7), purificados, digeridos com a enzima de restrição BamHI e analisados em gel de agarose $0,8 \%$. Foram obtidos 9 plasmídeos que apresentaram os perfís de migração esperados em gel de agarose, apresentando duas bandas: uma referente ao cassete de 
expressão pPGKspt15*tPGK (2.615 pb) e outra ao vetor pCR $^{\circledR} 2.1$-TOPO ${ }^{\circledR}$ (Invitrogen) (3.900 pb) (Figura 11).

Esta clonagem foi realizada para hospedar o cassete de expressão $\operatorname{spt} 15^{*} \mathrm{e}$ posterior obtenção deste fragmento contendo nas extremidades sítios para a enzima de restrição BamHI, necessárias para a última etapa de clonagem no plasmídeo integrativo

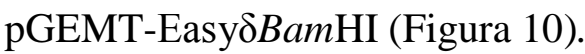
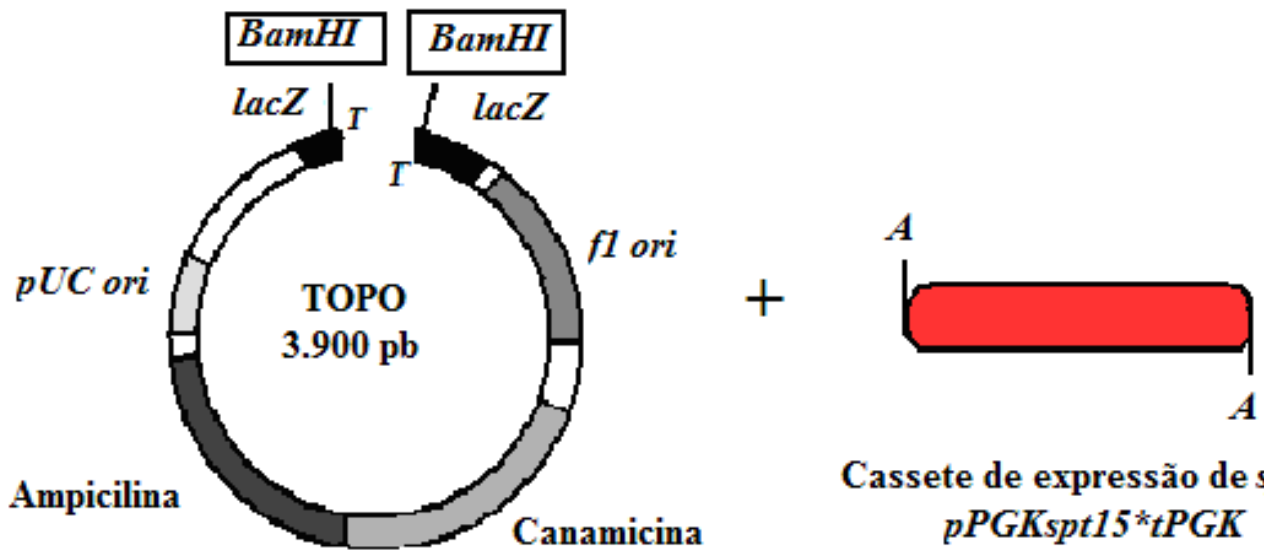

Cassete de expressão de spt15* pPGKspt $15^{\star} t P G K$
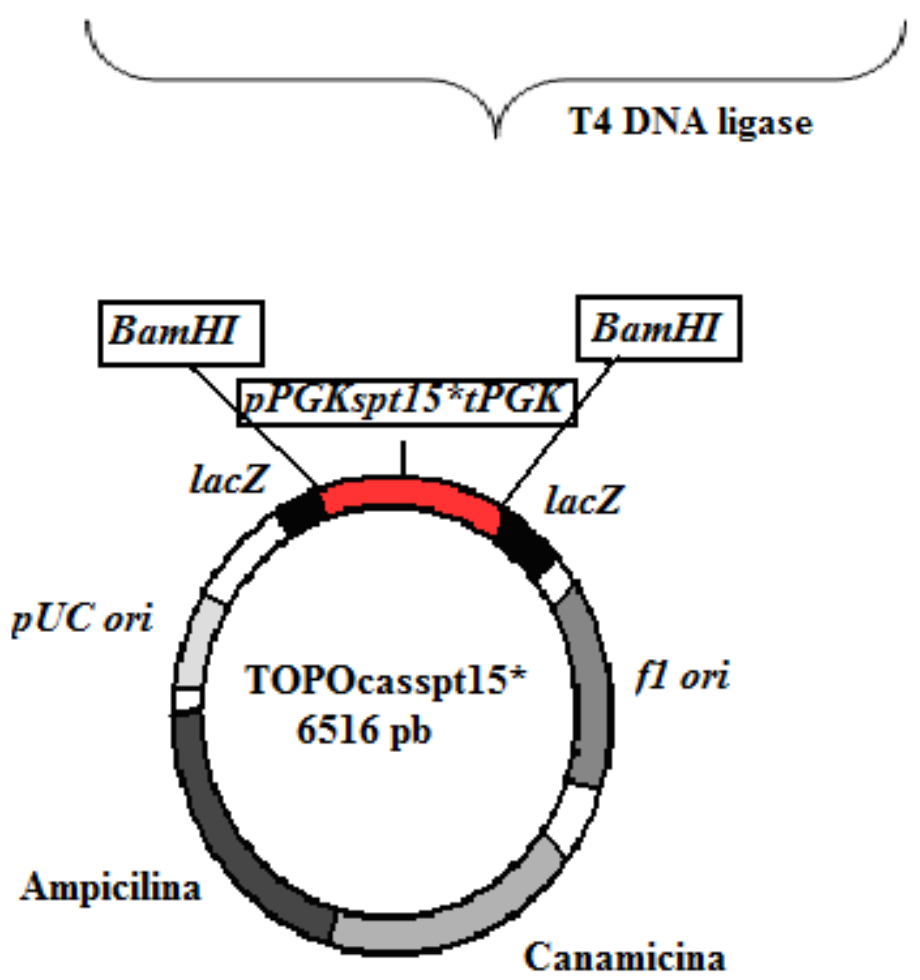

Figura 10. Esquema da clonagem do cassete de expressão (pPGKspt 15 *tPGK) no vetor comercial $\mathrm{pCR}^{\circledR}$ 2.1-TOPO ${ }^{\circledR}\left(\right.$ Invitrogen $\left.^{\mathrm{TM}}\right)$. 


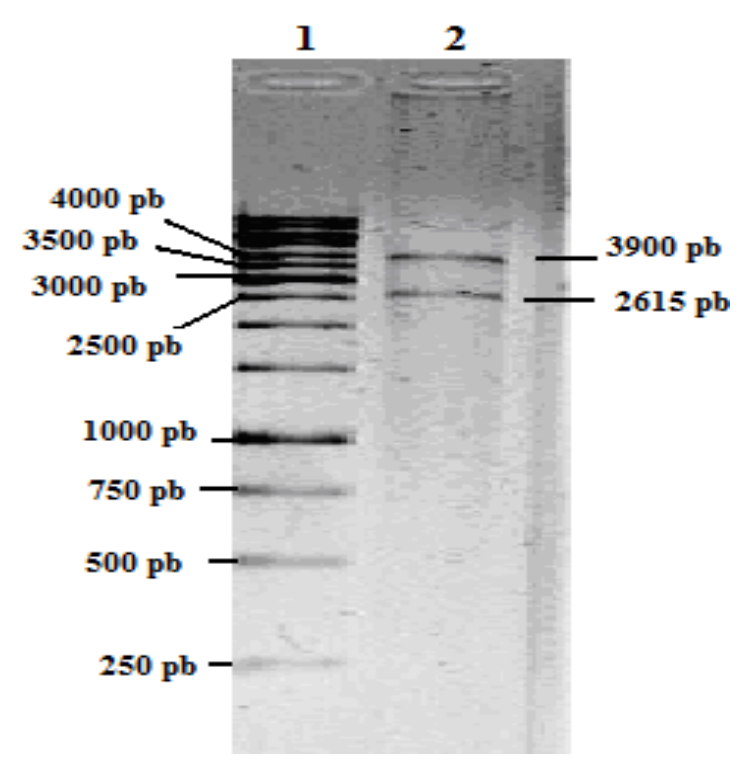

Figura 11. Perfis de migração em gel de agarose $0,8 \%$ corado com brometo de etídio e submetido à eletroforese das digestões do plasmídeo TOPOcasspt $15 *$ digerido com a enzima de restrição BamHI; 1) marcador $1 \mathrm{~Kb}$ Ladder (50 ng); 2) plasmídeo recombinante (TOPOcassetespt15*) digerido com a enzima de restrição BamHI, onde a banda de $2615 \mathrm{pb}$ se refere ao cassete spt15* e a de 3900 pb se refere ao plasmídeo pCR ${ }^{\circledR} 2.1-$ TOPO $^{\circledR}\left(\right.$ Invitrogen $\left.^{\text {TM}}\right)$.

4.3.2 Clonagem do cassete de expressão pPGKspt15*tPGK no plasmídeo pGEMTEasy $\delta$ BamHI

O cassete de expressão de $\operatorname{spt} 15 *(2615$ pb) com extremidade BamHI foi obtido por digestão do DNA plasmidial do clone da bactéria E. coli DH5 $/$ TOPOcasspt15* (Material e Métodos, item 3.10) e purificação do gel de agarose 0,8\% (Figuras 10 e 11).

O plasmídeo pGEMT-Easy $\delta$ BamHI foi digerido com a enzima BamHI, a mistura de ligação entre o plasmídeo pGEMT-Easy $\delta$ BamHI e o fragmento que corresponde ao cassete de expressão pPGKspt15*tPGK (Material e Métodos, item 3.12) foi empregada na transformação de E. coli DH5a (Material e Métodos, item 3.15). O cassete de

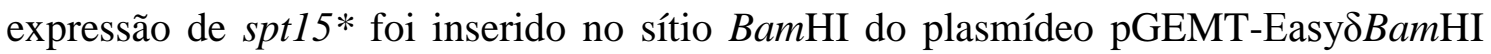
dentro do elemento $\delta$ do transposon Ty1 (Figura 12). Foram obtidos 56 transformantes na bactéria E. coli DH5a. O DNA plasmidial de 36 clones transformantes escolhidos ao acaso, foram extraídos (Material e Métodos, item 3.7), purificados e digeridos com as enzimas de restrição BamHI, BglII e EcoRI e analisados em gel de agarose 0,8\% (Figuras 13 e 14). Destes transformantes, 8 apresentaram perfis de bandas desejadas.

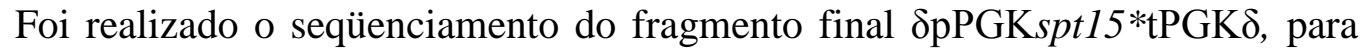
confirmar que todas as fusões desejadas e o gene $s p t 15^{*}$ estavam corretos. Os resultados mostraram que toda a sequiência estava correta (Material e Método, item 3.14.2). 

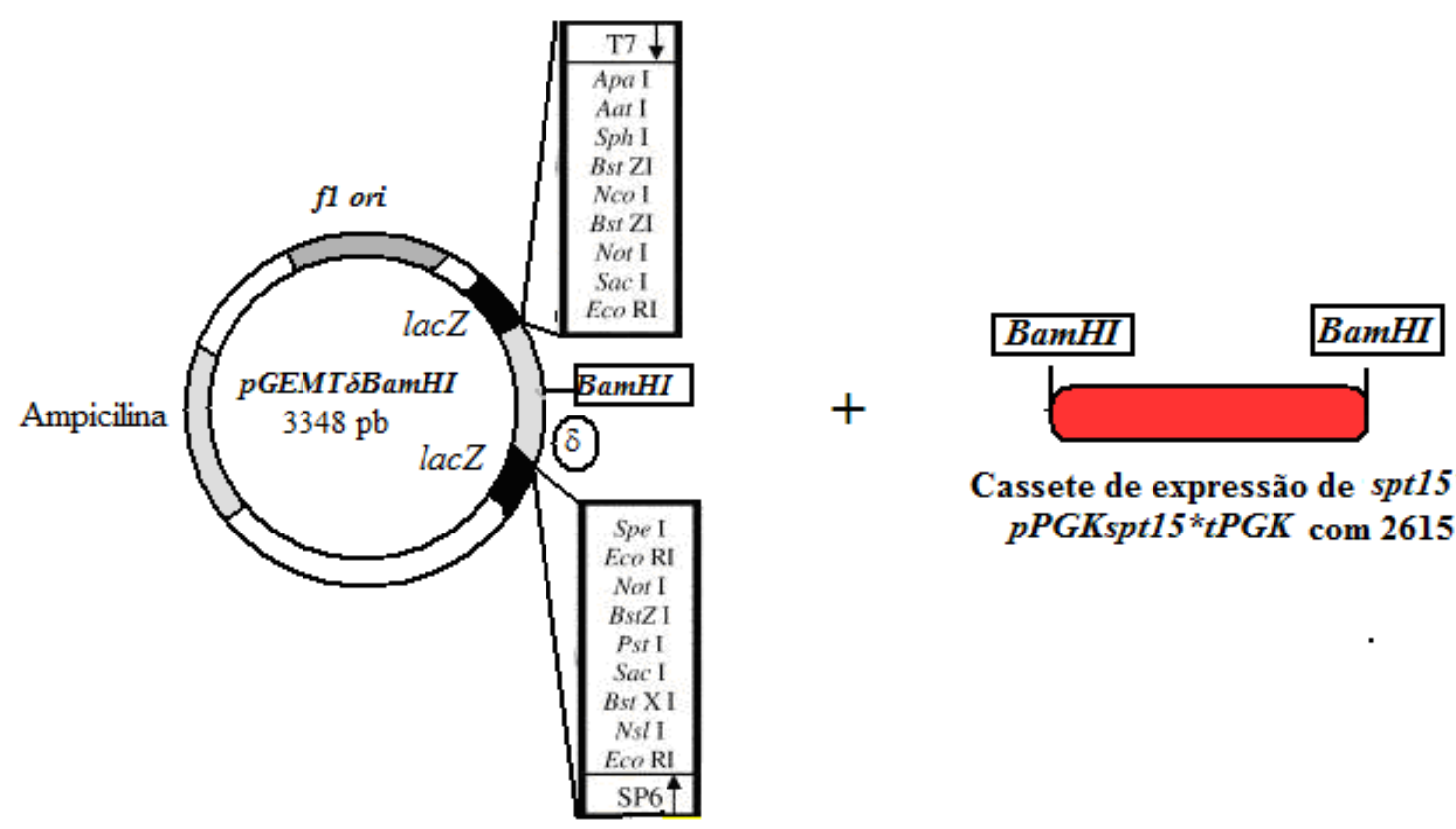

Cassete de expressão de $s p t 15^{*}$ : $p P G K s p t 15^{\star} t P G K$ com 2615 pb
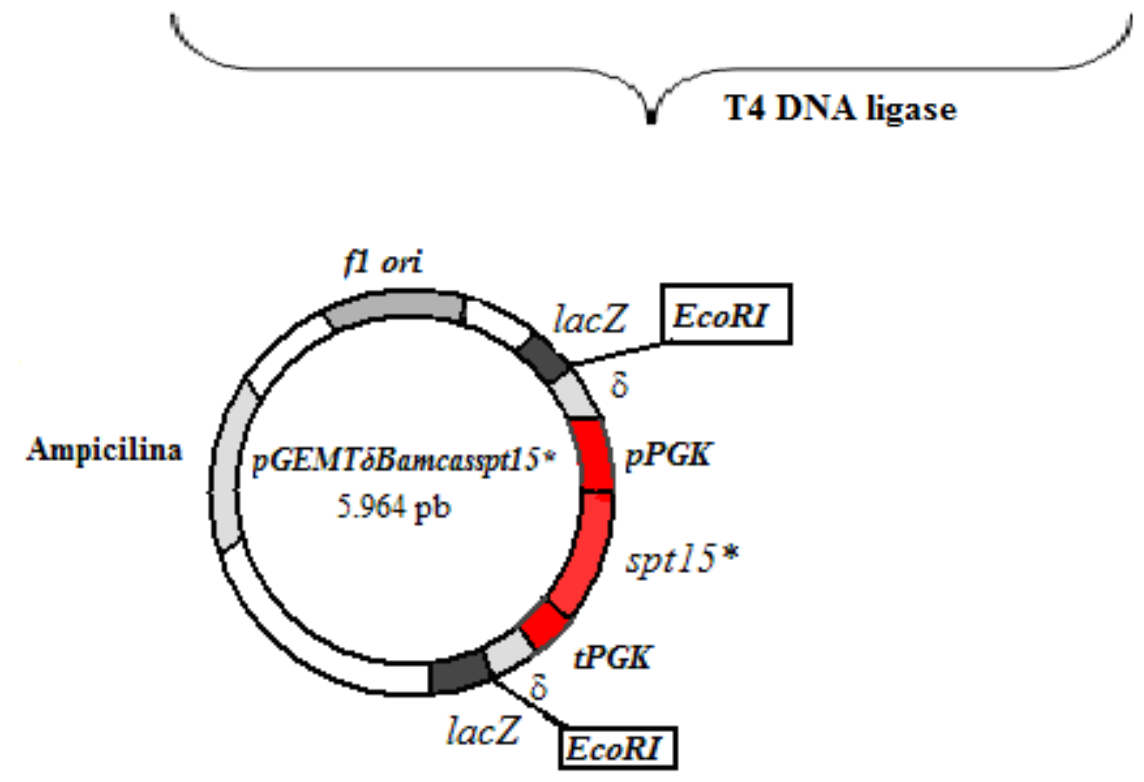

Digestão com a enzima EcoRI: retira o fragmento de interesse $\delta p P G K s p t 15 * t P G K \delta$.

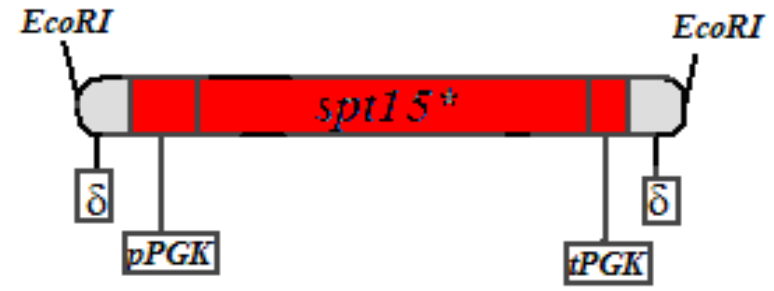

Fragmento de DNA usado para transformação de linhagens de $S$. cerevisiae.

Figura 12. Esquema da clonagem do cassete de expressão de spt15* no vetor integrativo pGEMTEasy $\delta$ BamHI, possuindo 5964pb e denominado pGEMTEasy $\delta$ Bamcasspt $15^{*}$. 


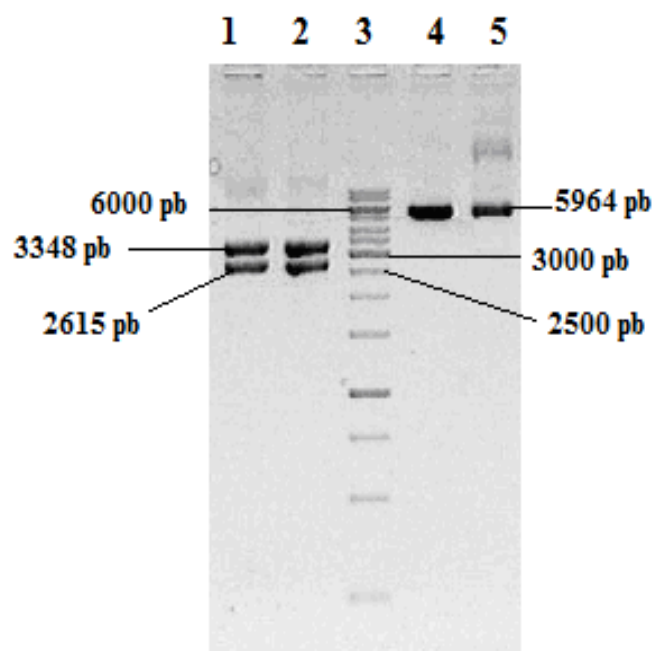

Figura 13. Perfis de migração em gel de agarose $0,8 \%$ corado com brometo de etídio e submetido à

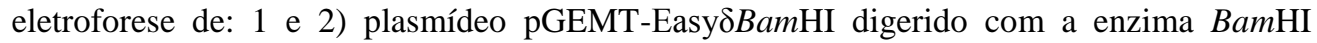
(fragmento de DNA de $3348 \mathrm{pb}$ e $2615 \mathrm{pb}$ ). 3) marcador de $1 \mathrm{~Kb}$ Ladder. 4 e 5) pGEMT-

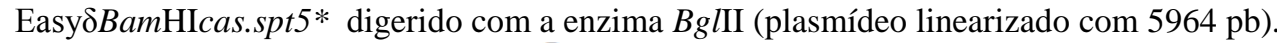

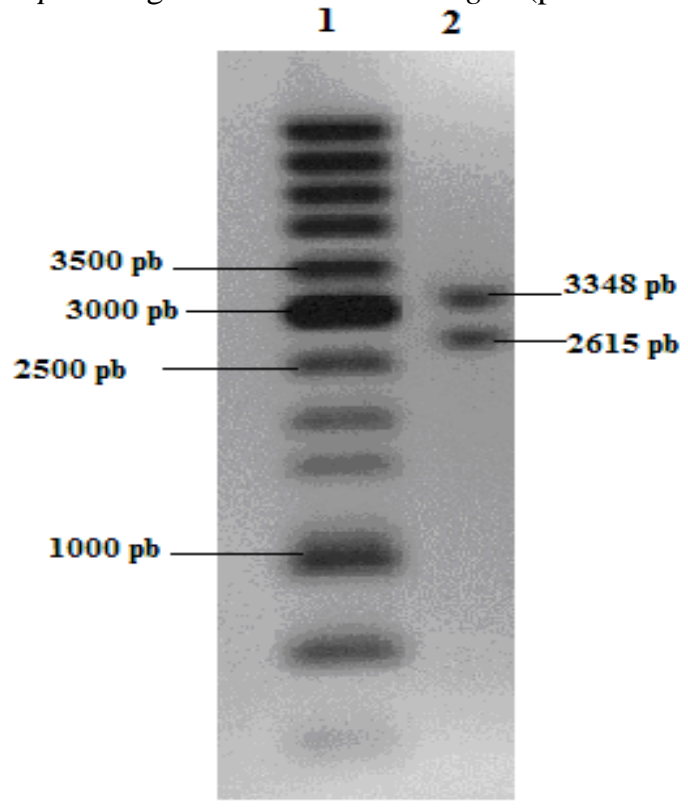

Figura 14. Perfis de migração em gel de agarose $0,8 \%$ corado com brometo de etídio e submetido à

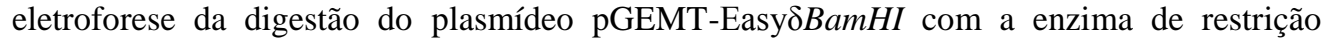
EcoRI: 1) marcador de $1 \mathrm{~Kb}$ Ladder e 2) análise por digestão de pGEMT-

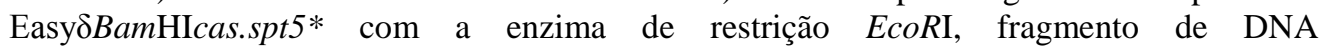
$\delta$ pPGKspt15*tPGK $\delta(2615$ pb) e plasmídeo pGEMT-Easy $\delta$ BamHI (3348 pb).

\subsection{Obtenção de transformantes da linhagem $S$. cerevisiae YPH252 com o

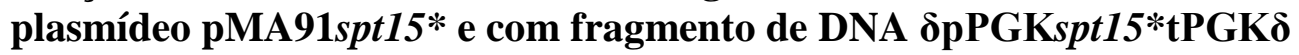

Foi realizada a transformação da linhagem S. cerevisiae YPH252 com o plasmídeo pMA91spt15* e com fragmento de DNA $\delta p P G K s p t 15 * t P G K \delta$. 
4.4.1 Transformação de YPH252 com o plasmídeo pMA91spt15*

A linhagem YPH252 foi transformada com o plasmídeo recombinante pMA91spt15*, e com o plasmídeo pMA91(controle), utilizando-se $3 \mu \mathrm{g}$ de cada plasmídeo. Os clones transformantes foram selecionados por complementação gênica do fenótipo Leu ${ }^{+}$em meio mínimo (SD-THUAL) (Tabela 5).

Tabela 5- Eficiência de transformação da linhagem YPH252 com o plasmídeo pMA91spt15*.

\begin{tabular}{cccc}
\hline Plasmídeos & Quantidade & $\begin{array}{c}\text { Número de } \\
\text { Transformantes }\end{array}$ & $\begin{array}{c}\text { Eficiência de Transformação } \\
\text { (n'Transformantes/ } \boldsymbol{\mu g} \text { DNA) }\end{array}$ \\
\hline pMA91spt15* & $3 \mu \mathrm{g}$ & 4.342 & $1,447 \times 10^{5}$ \\
pMA91 & $3 \mu \mathrm{g}$ & 6.219 & $2,073 \times 10^{5}$ \\
\hline
\end{tabular}

\subsubsection{Transformação de YPH252 com o fragmento de DNA $\delta p P G K s p t 15 * t P G K \delta$}

O fragmento de DNA $\delta$ PPGKspt15*tPGK $\delta$ foi introduzido na linhagem YPH252, empregando-se co-transformação com o plasmídeo pAJ50. O plasmídeo pAJ50 foi empregado sozinho numa transformação controle.

Etapa 1: Seleção dos clones por complementação gênica

Os transformantes foram selecionados em meio mínimo sem leucina (SD-THUAL) (Tabela 6).

Tabela 6- Eficiência de transformação da linhagem YPH252 com o fragmento de DNA $\delta$ pPGKspt $15 * \operatorname{tPGK} \delta$.

\begin{tabular}{cccc}
\hline DNAs & Quantidade & $\begin{array}{c}\text { Número de } \\
\text { Transformantes }\end{array}$ & $\begin{array}{c}\text { Eficiência de } \\
\text { Transformação do } \\
\text { plasmídeo pAJ50 } \\
\text { (n'Transformantes/ } \boldsymbol{\mu g} \\
\text { DNA) }\end{array}$ \\
\hline $\begin{array}{c}\text { pAJ50 } \\
\text { spPG spt15*tPGK } \delta \\
+ \text { pAJ50 }\end{array}$ & $6 \mu \mathrm{g}+6 \mu \mathrm{g}$ & 1.322 & $0,385 \times 10^{3}$ \\
\hline
\end{tabular}


Etapa 2: Seleção dos clones recombinantes que receberam o fragmento de DNA $\delta$ pPGKspt15*tPGK $\delta$

Os clones recombinantes que receberam o fragmento de DNA $\delta$ pPGKspt15*tPGK $\delta$ foram selecionados dentre os transformantes inicialmente selecionados por complementação gênica obtidos com a mistura $\delta$ pPGKspt 15 *tPGK $\delta+$ pAJ50.

Para tanto, os clones recombinantes $\mathrm{Leu}^{+}$pré-selecionados foram cultivados em meio SD-THUAL 5\% de glicose e incubados em tubos de ensaio contendo tubos Durhan, em estufa, à $28^{\circ} \mathrm{C}$, por 48 hora. Aproximadamente, 100 clones escolhidos ao acaso foram testados e destes, apenas 3 clones apresentaram melhor desempenho de fermentação, sendo os primeiros a fermentar glicose, variando de 24, 27 e 28 horas, sendo o melhor clone, aquele que fermentou depois de 24 horas de incubação.

Para confirmação da $\delta$-integração do fragmento de DNA $\delta$ p PKspt15*tPGK $\delta$ no DNA genômico da linhagem de levedura laboratorial YPH252, o DNA genômico do melhor clone, foi isolado, purificado e empregado como molde em reação de PCR com oligonucleotídeos $\mathrm{PGK}_{\mathrm{Fw}}$ e $\mathrm{PGK}_{\mathrm{Rv}}$. Esta abordagem permitiu a confirmação da inserção do fragmento de DNA $\delta$ pPGKspt $15 *$ PGK $\delta$ integrado em seu genoma (Figura 15).

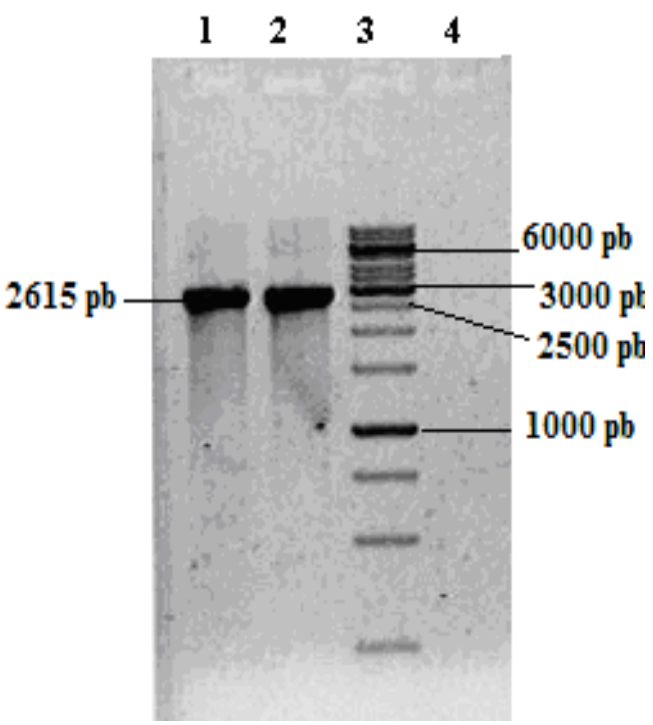

Figura 15. Perfís de migração em gel de agarose $0,8 \%$ corado com brometo de etídio, submetido a eletroforese do fragmento "SpPGKspt $15 * \operatorname{tPGK} \delta$ ” obtido por amplificação por PCR do

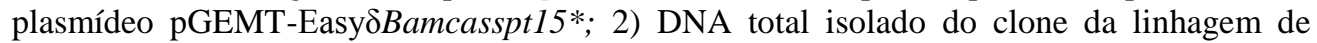
levedura YPH252 transformada com o fragmento $\delta$ pPGKspt15*tPGK $\delta$; 3) $1 \mathrm{~Kb}$ DNA Ladder Fermentas (150 ng) e 4) Controle negativo das amplificações por PCR. 


\subsection{Caracterização dos clones transformantes YPH252/pMA91spt15* e YPH252/

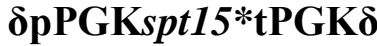

\subsubsection{Análise qualitativa}

Foi realizada uma análise qualitativa da capacidade de fermentação em glicose

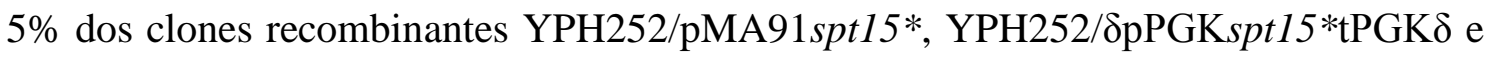
YPH252/pMA91 (controle) (Material e Métodos, item 3.18) (Figura 16). A linhagem

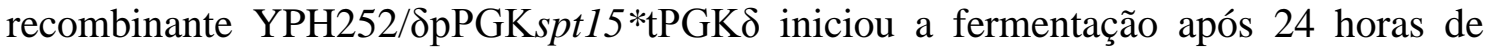
incubação em estufa, a $28^{\circ} \mathrm{C}$. A linhagem recombinante YPH252/pMA91spt15* (Figura 16B), inicia a fermentação a 36 horas de incubação; e a fermentação da linhagem recombinante YPH252/pMA91 (controle) (Figura 16C) somente iniciou a 48 horas de incubação (Figura 16D).

Conforme o esperado as linhagens recombinantes

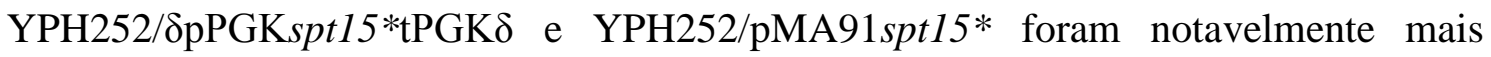
eficientes no processo de fermentação que a linhagem recombinante YPH252/ pMA91 (controle).
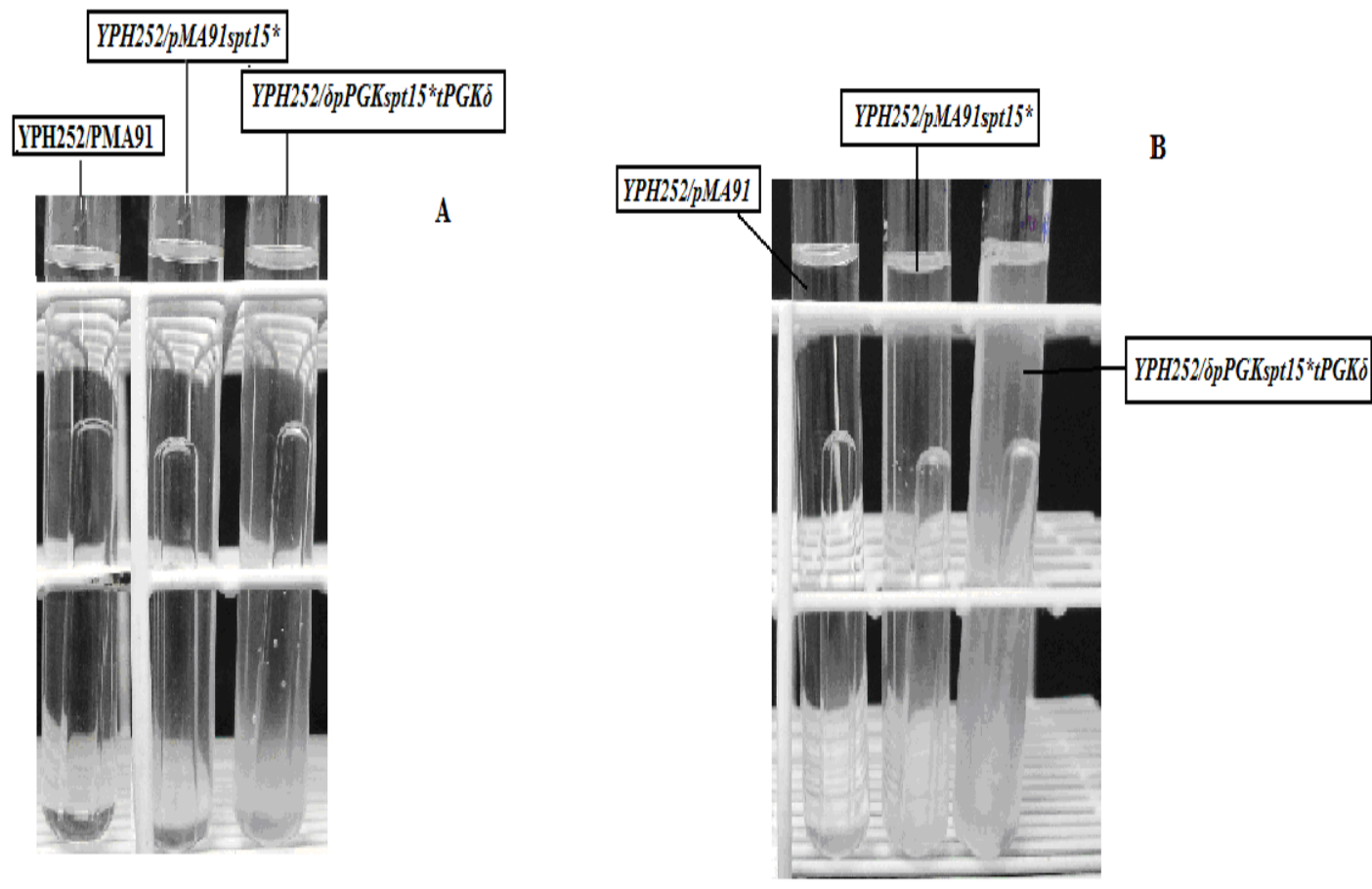

Continua 
Conclusão
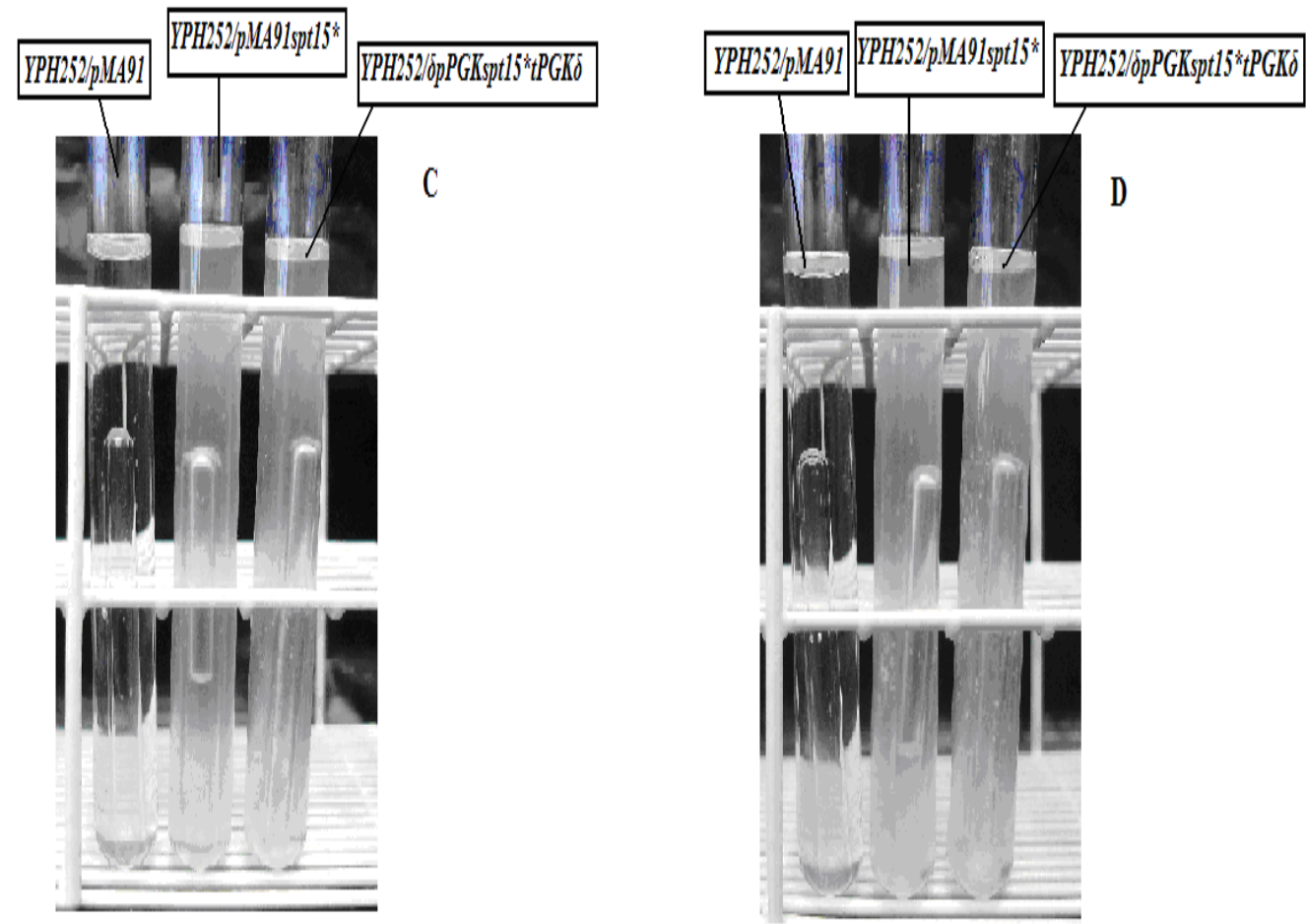

Figura 16. Ensaio de fermentação da linhagem YPH252 transformada com os plasmídeos pMA91 (controle) e pMA91spt15* (Figura 12); e, como o fragmento $\delta$ pPGKspt15*tPGK $\delta$ (Figura 16). Os ensaios foram realizados em meio SD-THUAL $5 \%$ glicose em tubos contendo tubo Durhan, incubados em estufa, a $28{ }^{\circ} \mathrm{C}$ e observados a cada 12 horas de incubação. Foto da análise biológica de fermentação depois de incubação por: 24 horas, onde se observa. B) 36 horas, onde também foi observada a fermentação da linhagem recombinante YPH252/pMA91spt15*; C) 48 horas, na qual ocorreu fermentação da linhagem YPH252/pMA91; D) ensaio de fermentação depois de 60 horas de incubação.

Foi realizada uma análise qualitativa da capacidade de fermentação em glicose

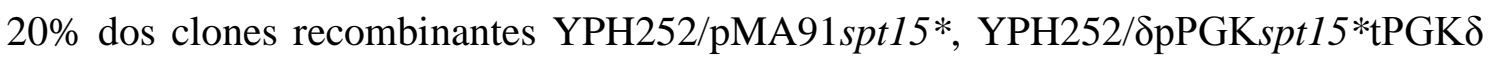
e YPH252/pMA91 (controle) (Material e Métodos, item 3.18) (Figura 17). A linhagem recombinante YPH252/ $\delta$ pPGKst15*tPGK $\delta$ iniciou a fermentação após 24 horas de incubação em estufa, a $28^{\circ} \mathrm{C}$ (Figura 17A), sendo a primeira a fermentar. Após 48 horas de incubação, também foi observado a fermentação da linhagem recombinante YPH252/pMA91spt15* (Figura 17C). Após 60 horas de incubação, foi constatada a fermentação da linhagem recombinante YPH252/pMA91 (controle) (Figura 17D). Após 72 horas de incubação em estufa, a $28^{\circ} \mathrm{C}$, todas as leveduras estavam fermentando,

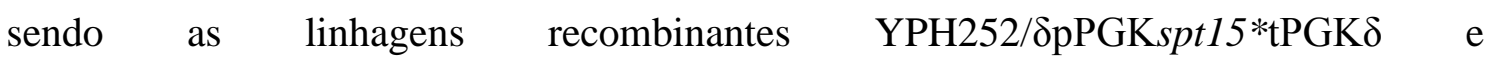
YPH252/pMA91spt15* apresentando maior formações de bolhas (Figura 17E). 


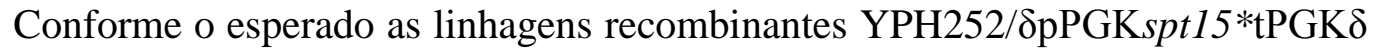
e YPH252/pMA91spt15* foram notavelmente mais eficientes no processo de fermentação que a linhagem recombinante YPH252/ pMA91 (controle).

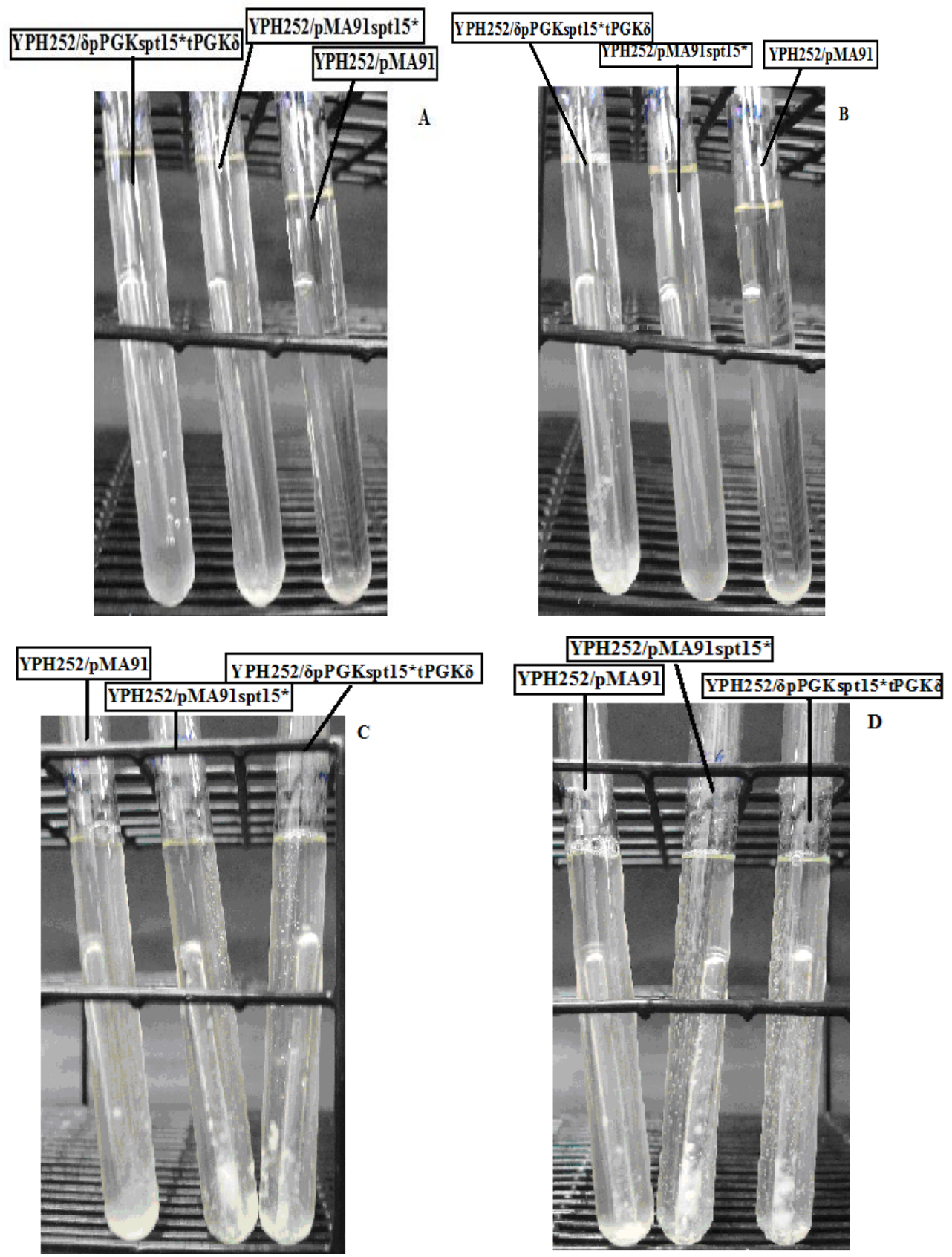

Continua 
Conclusão
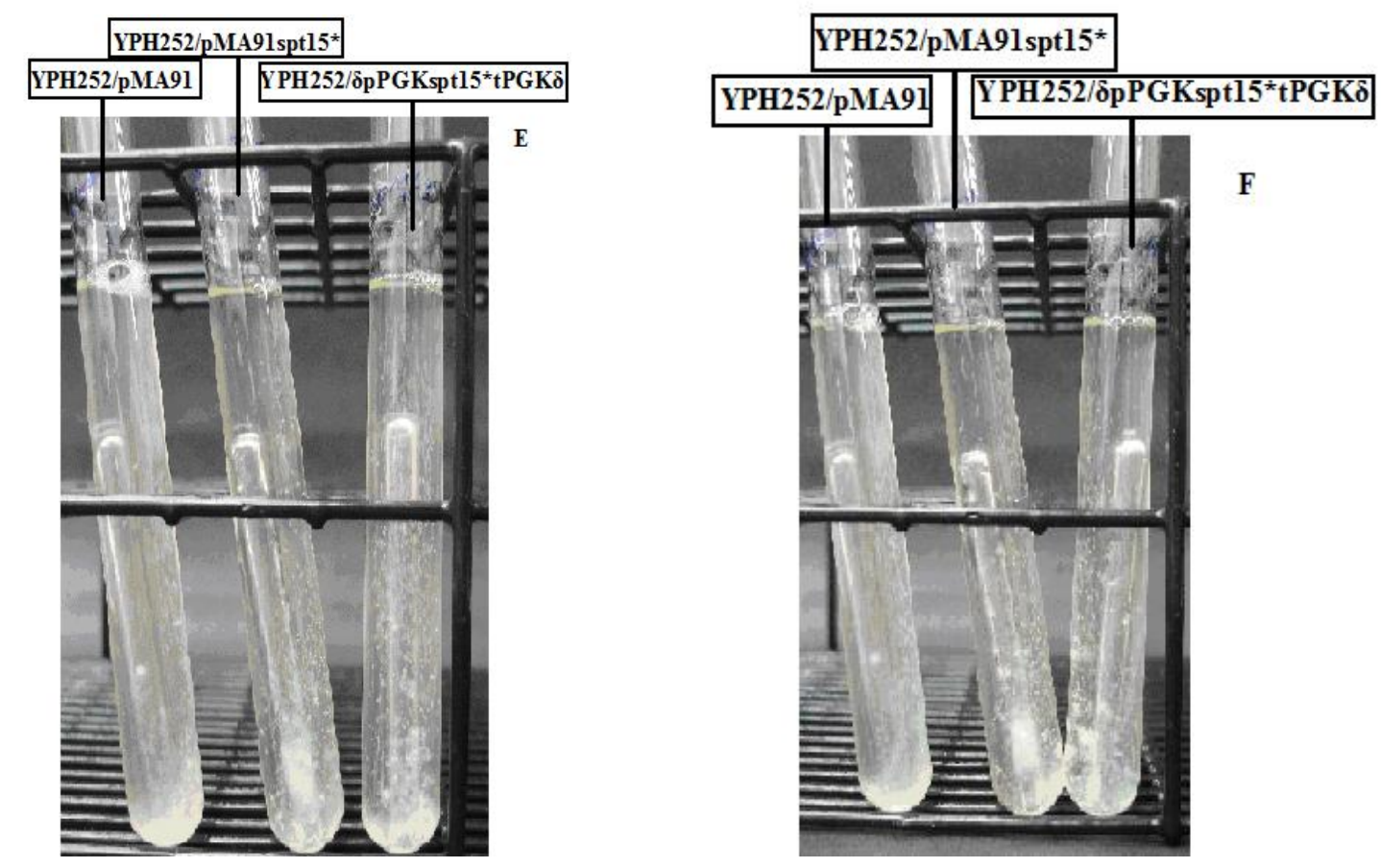

Figura 17. Ensaio de fermentação da linhagem YPH252 transformada com os plasmídeos pMA91 (controle) e pMA91spt15* (Figura 12); e, como o fragmento $\delta$ pPGKspt15*tPGK $\delta$ (Figura 15). Os ensaios foram realizados em meio SD-THUAL $20 \%$ glicose em tubo contendo tubo Durhan, incubados em estufa, a $28{ }^{\circ} \mathrm{C}$ e observados a cada 12 horas de incubação. Foto da análise biológica de fermentação depois de incubação por: 24 horas, onde foi observada a

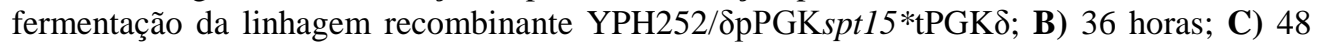
horas, onde a linhagem recombinante YPH252/pMA91 spt15* começou a fermentar; D) 60 horas, onde a linhagem recombinante YPH252/pMA91, começou a fermentar. E) 72 horas, na qual as linhagens recombinantes YPH252/pMA91spt15* e YPH252/סpPGKspt15*tPGK $\delta$ liberam grande quantidade de bolhas. F) 84 horas.

\subsubsection{Análise da curva de crescimento das leveduras recombinantes}

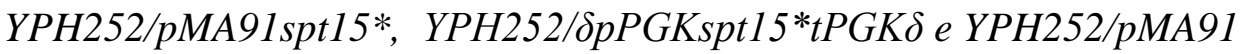

As curvas de crescimento dos clones transformantes YPH252/pMA91spt15*,

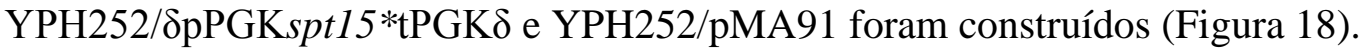

Para tanto, os clones transformantes foram cultivados em meio YPD líquido, contendo $5 \%$ de glicose, durante 120 horas, e as alíquotas foram retiradas a cada 12 horas (Materiais e Métodos, item 3.20).

De acordo com essa análise, as linhagens transformantes YPH252/pMA91spt15*

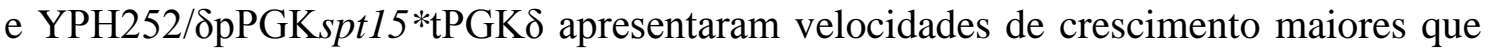
a linhagem controle YPH252/pMA91 (Figura 18). Entendeu-se que este comportamento seja resultante da reprogramação do metabolismo da linhagem hospedeira YPH252, por 
meio do fator de transcrição codificado pelo gene SPT15 mutagenizado em três diferentes posições $(\operatorname{spt} 15 *)$

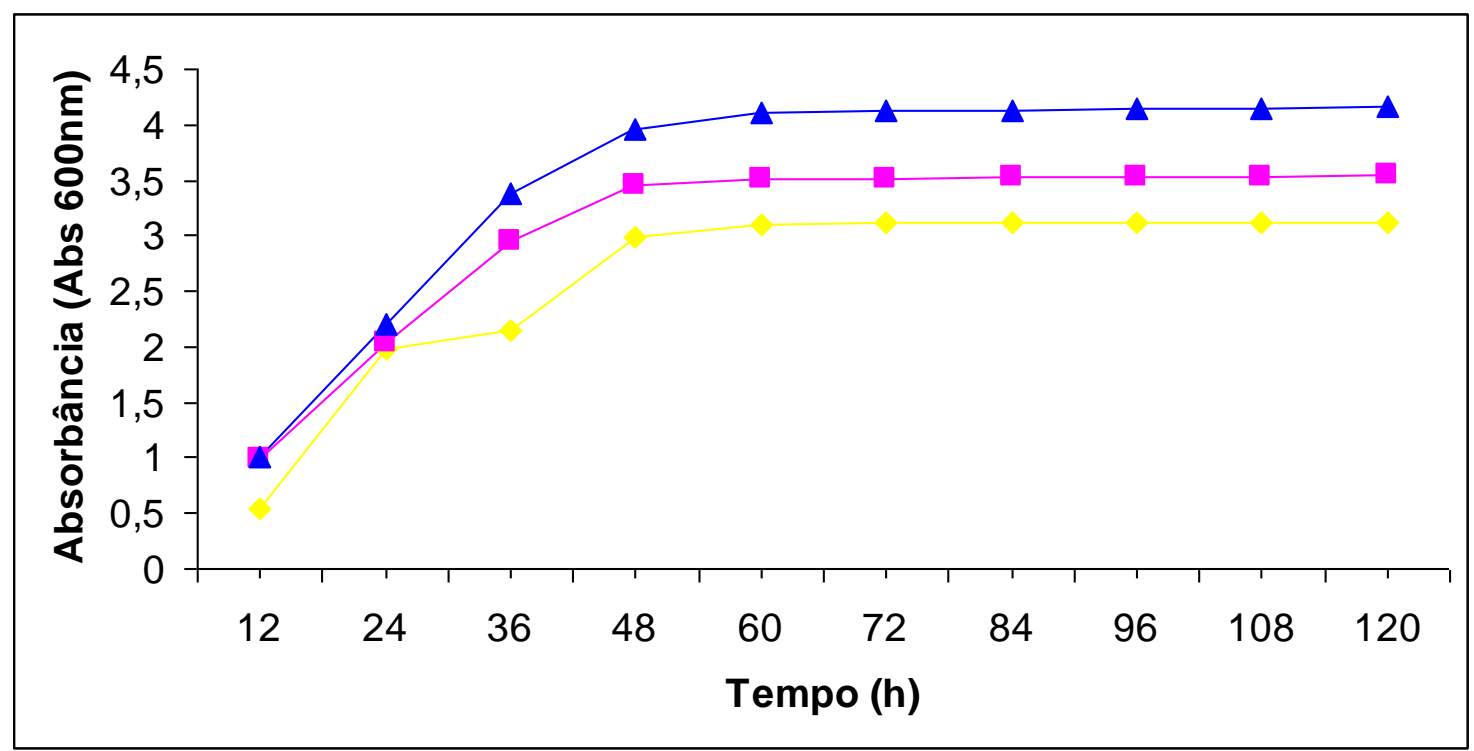

Figura 18. Curvas de crescimento em meio YPD (5\% glicose) das linhagens YPH252/pMA91spt15*

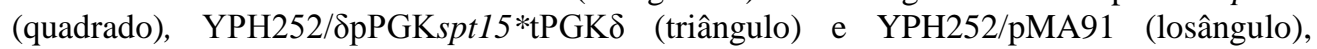
cultivadas a $28^{\circ} \mathrm{C}$, com aeração em frascos agitados em "shaker".

Também, as curvas de crescimento dos clones transformantes das linhagens

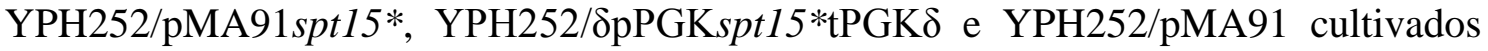
em meio YPD líquido, contendo $20 \%$ de glicose, foram construídos.

De acordo com essa análise, as linhagens transformantes YPH252/pMA91spt15*

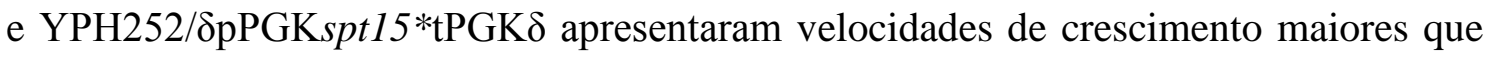
a linhagem controle YPH252/pMA91 (Figura 19). Entendeu-se que o comportamento observado em meio YPD $20 \%$ glicose foi inferior ao observado em meio YPD 5\% glicose (Figura 19). Entretanto, em ambos os ensaios com meio YPD 5\% glicose e 20\% glicose, as linhagens recombinantes YPH252/pMA91spt15* e

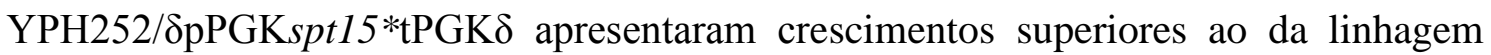
recombinante controle YPH252/pMA91 (Figuras 18 e 19). 


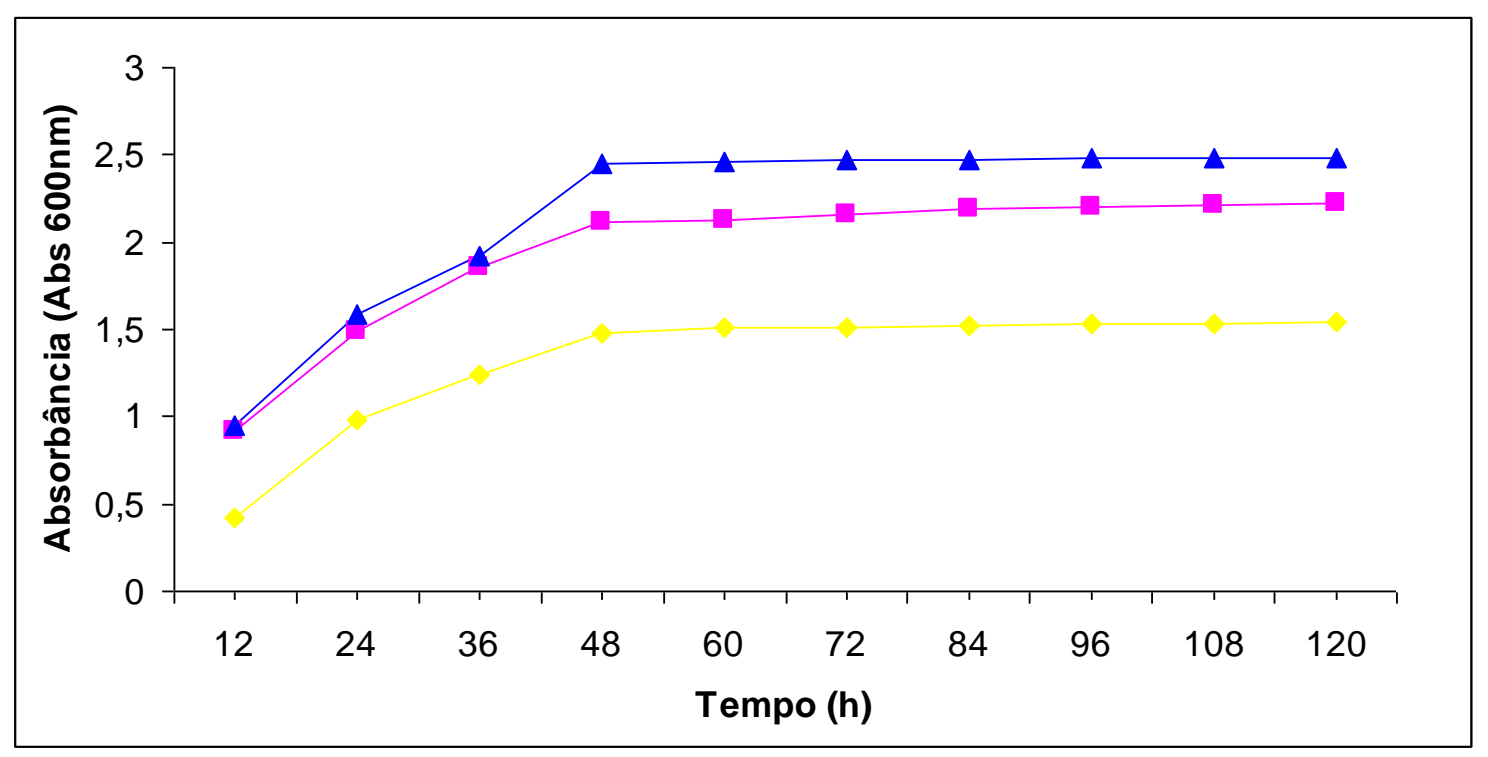

Figura 19. Curvas de crescimento em meio YPD (20\% glicose) das linhagens, YPH252/pMA91spt15*

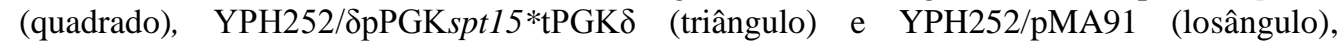
cultivadas a $28{ }^{\circ} \mathrm{C}$, com aeração em frascos com agitação em "shaker".

\subsubsection{Análise do peso da massa seca das leveduras recombinantes}

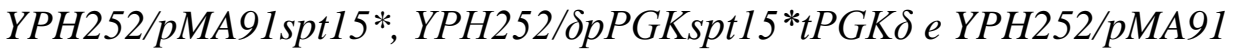

O peso da massa seca das leveduras recombinantes YPH252/pMA91spt15*,

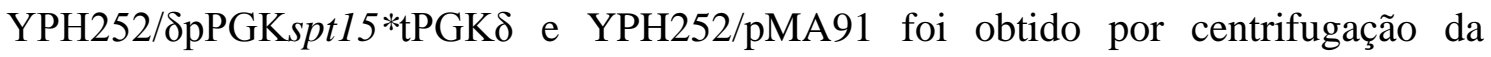
alíquota de $1 \mathrm{~mL}$ retirada a cada oito horas do cultivo em meio SD-THUAL (Material e Métodos, item 3.5) em estufa à $28^{\circ} \mathrm{C}$, por 80 horas. $\mathrm{O}$ sedimento obtido foi seco em estufa à $37^{\circ} \mathrm{C}$, por 48 horas e pesado em balança analítica. Foram realizados dois ensaios com diferentes concentrações de glicose: com 5\% de glicose (Figura 20) e com $20 \%$ glicose (Figura 21). 


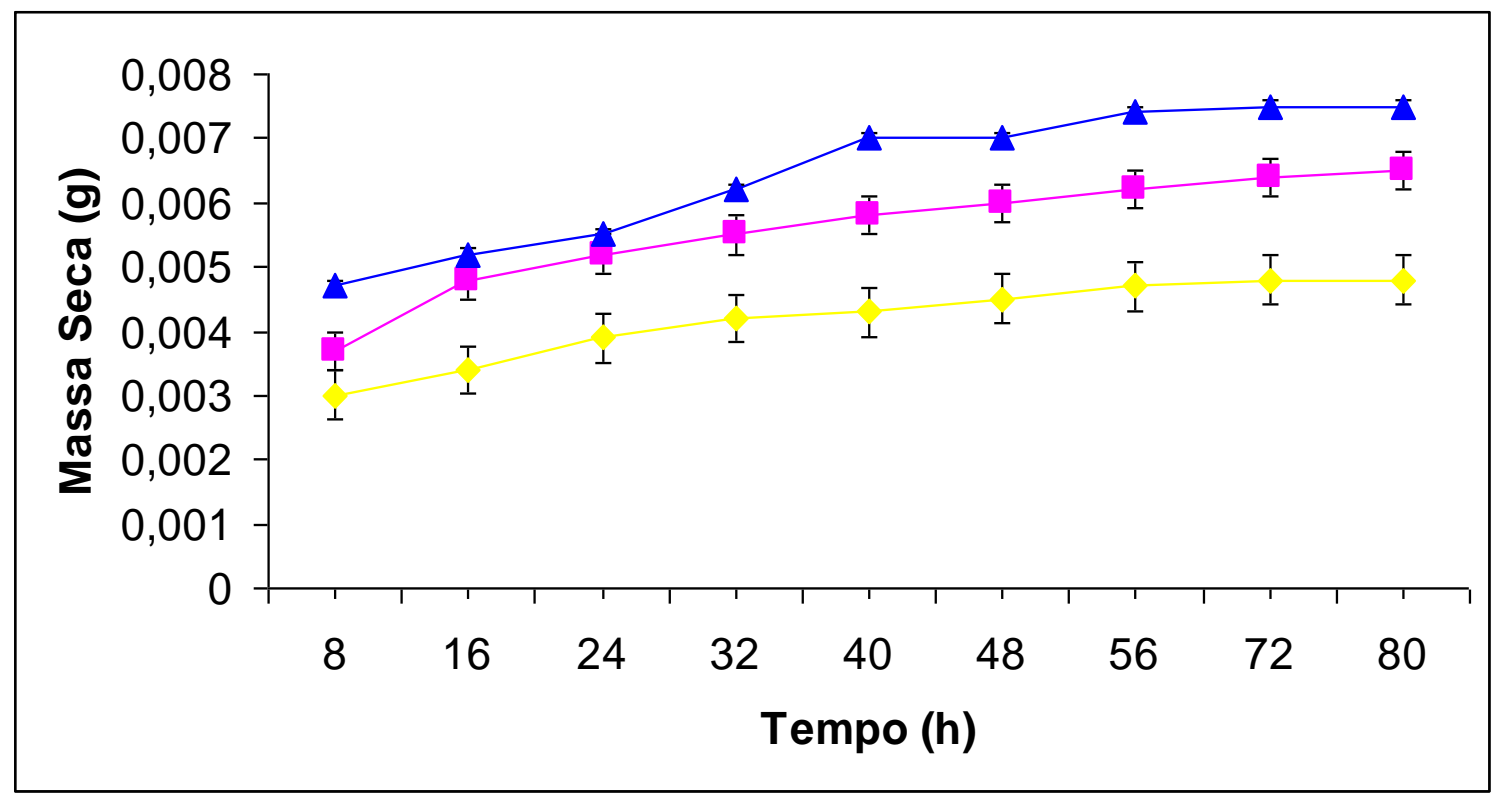

Figura 20. Peso em gramas da massa seca obtida do cultivo das linhagens YPH252/pMA91spt15*

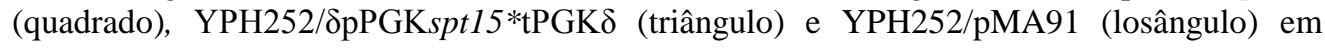
meio SD-THUAL (5\% glicose) em estufa, a $28{ }^{\circ} \mathrm{C}$, por 80 horas.

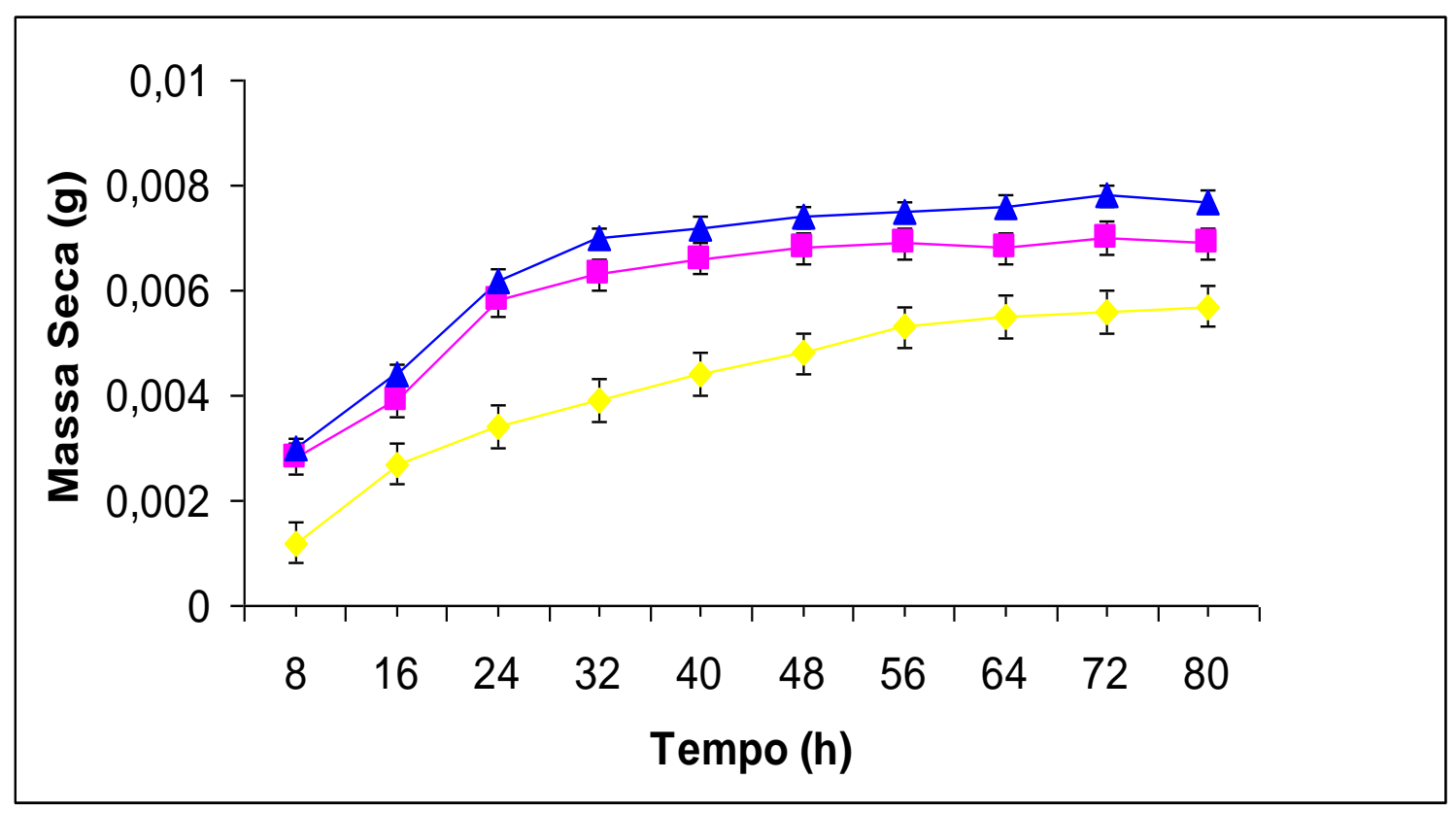

Figura 21. Peso em gramas da massa seca obtida do cultivo das linhagens YPH252/pMA91spt15*

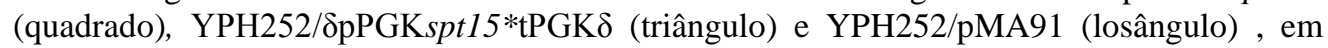
meio SD-THUAL (20\% glicose) em estufa, a $28{ }^{\circ} \mathrm{C}$, por 80 horas. 
4.5.4 Análise da concentração inibitória mínima dos clones YPH252/pMA91spt15*e

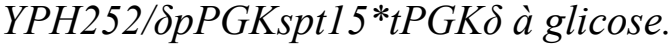

Os clones portadores do alelo triplo mutado spt15* (YPH252/pMA91 e

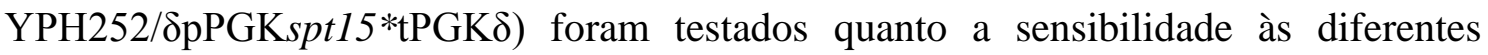
concentrações de glicose. A mínima concentração inibitória de glicose que inibe o crescimento (MIC) (Tabela 7), foi realizada em meio SD-THUAL líquido (Material e Métodos, itens 3.5 e 3.21), em diferentes concentrações de glicose, com aeração em “shaker", após 48 horas (Figura 22). 


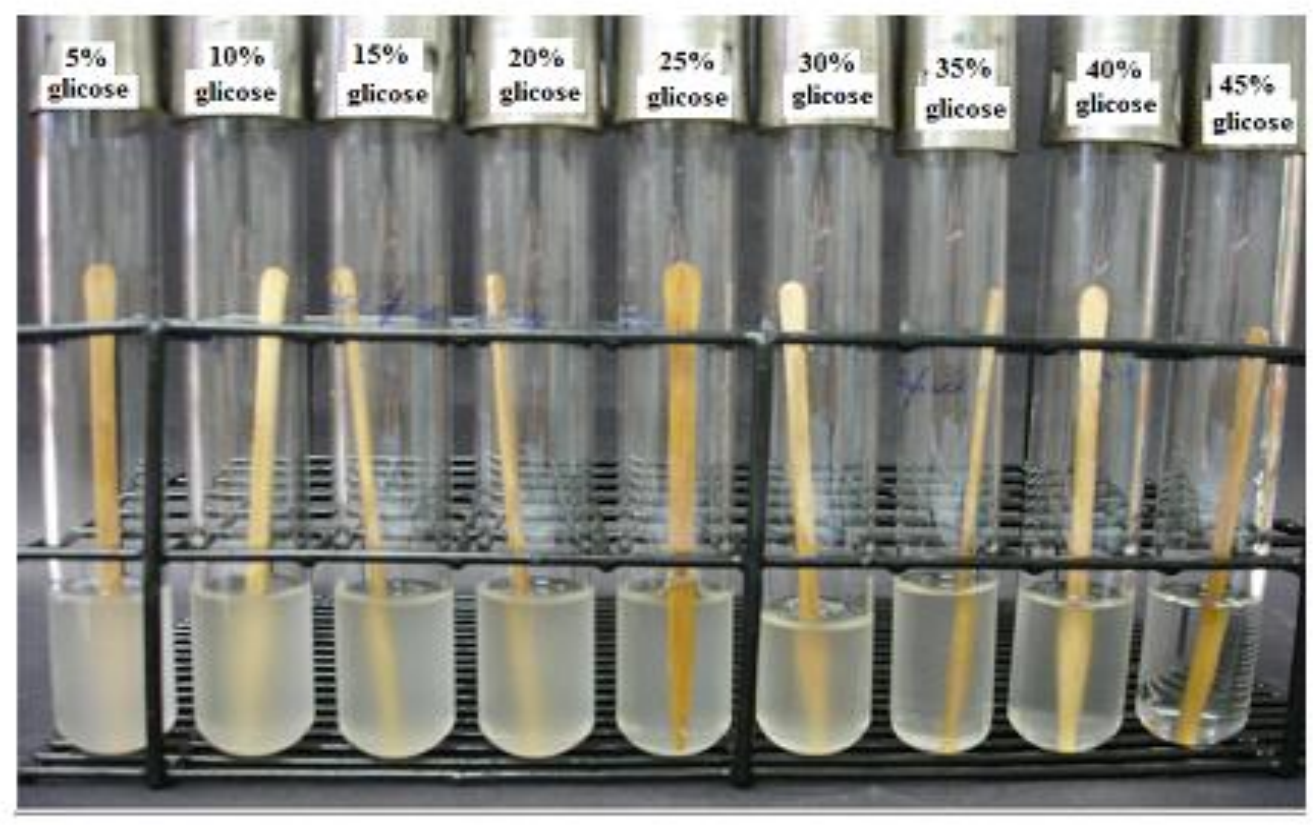

A

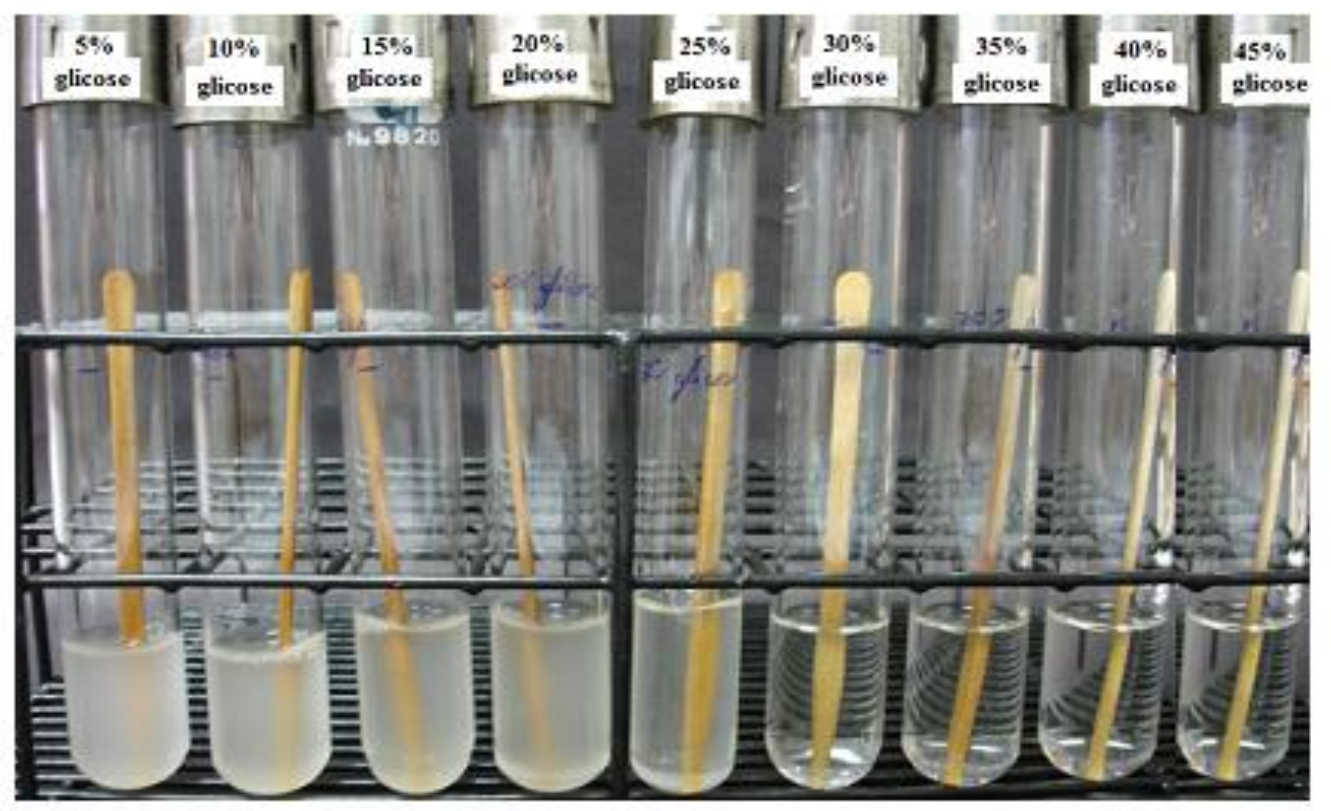

Figura 22. Foto do ensaio da determinação da concentração mínima inibitória (MIC) de glicose nas linhagens recombinantes, cultivadas em meio SD-THUAL, à $28{ }^{\circ} \mathrm{C}$, com aeração em

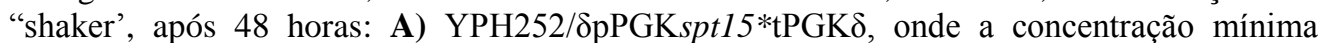
inibitória foi $45 \%$ de glicose; e, B) YPH252/pMA91, onde a concentração mínima inibitória foi $30 \%$ de glicose.

Tabela 7 - Sensibilidade das linhagens recombinantes YPH252/סpPGKspt15*tPGK $\delta$ e YPH252/pMA91 à glicose.

\begin{tabular}{|c|c|}
\hline Linhagens recombinantes & Concentração Mínima Inibitória (MIC) \\
\hline 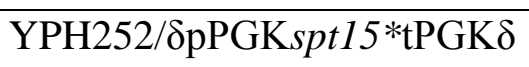 & $\leq 45 \%$ \\
\hline YPH252/pMA91 (controle) & $\leq 30 \%$ \\
\hline
\end{tabular}


A sensibilidade dos clones recombinantes a altas concentrações de açúcar foi avaliada após 48 horas de cultivo em meio SD-THUAL, em diferentes concentrações de glicose à $28^{\circ} \mathrm{C}$, com agitação em “shaker” (Figura 23) (Material e Métodos, item 3.21).

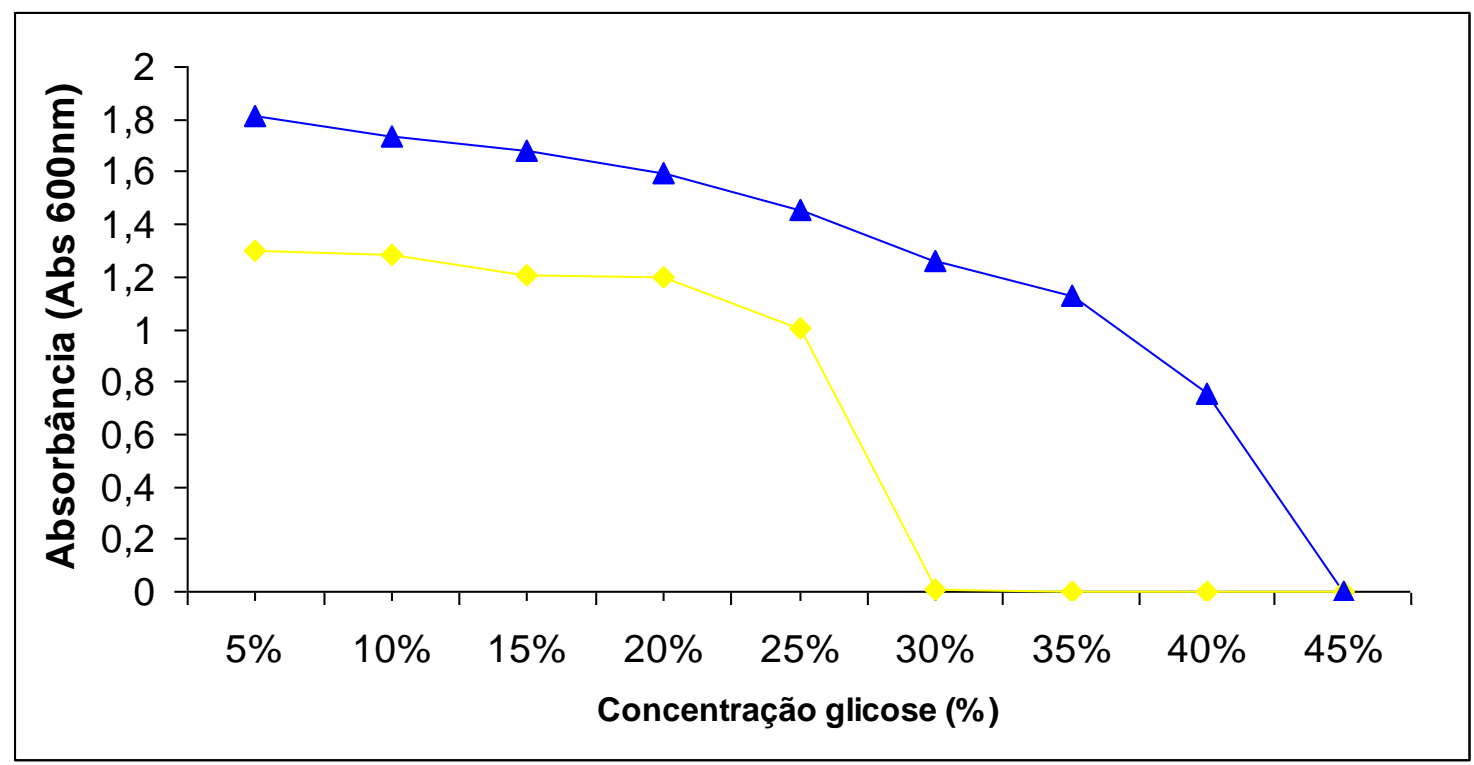

Figura 23. Análise da concentração mínima inibitória (MIC) das linhagens recombinantes

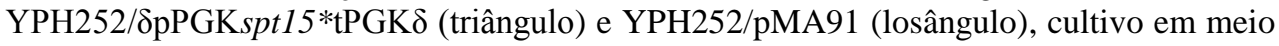
SD-THUAL, à $28^{\circ} \mathrm{C}$, com agitação em frascos no "shaker", após 48 horas.

4.5.5 Análise quantitativa do consumo de glicose dos recombinantes

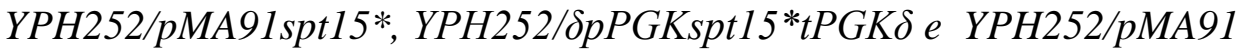

As curvas de consumo de glicose dos clones recombinantes

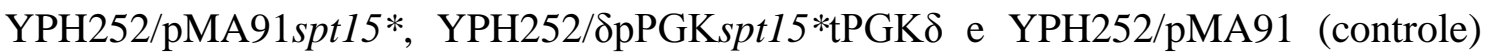
foram determinadas avaliando-se as capacidades de consumo de glicose durante ensaios de fermentação, por 80 horas, em meio SD-THUAL contendo 5\% de glicose (Figura 24) e $20 \%$ de glicose em estufa, a $28^{\circ} \mathrm{C}$ (Figura 25) (Material e Métodos, item 3.22).

De acordo com essa análise, os recombinantes YPH252/pMA91spt15* e

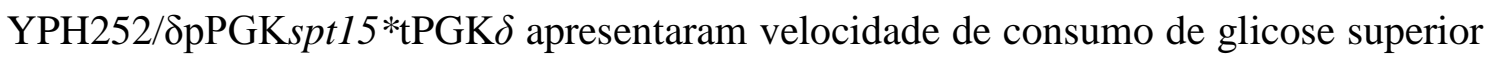
ao da linhagem YPH252/pMA91 que não possui o alelo triplo mutado spt15* (Figuras 24 e 25). 


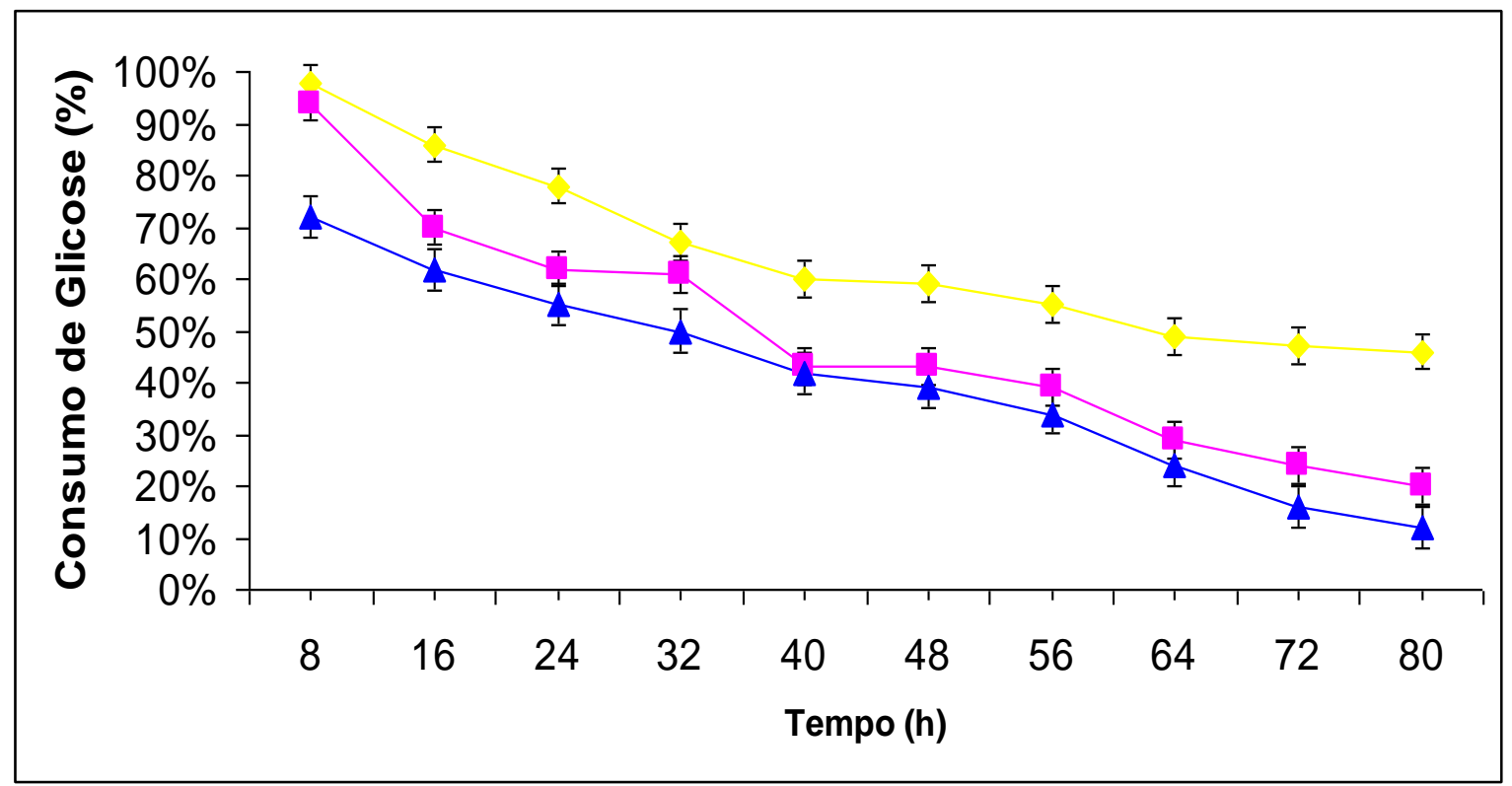

Figura 24. Gráfico do consumo de glicose do ensaio de fermentação dos clones YPH252/pMA91 spt15*

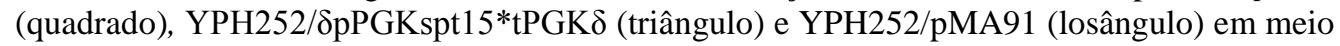
SD-THUAL ( $5 \%$ de glicose), cultivadas em estufa, a $28{ }^{\circ} \mathrm{C}$, por 80 horas.

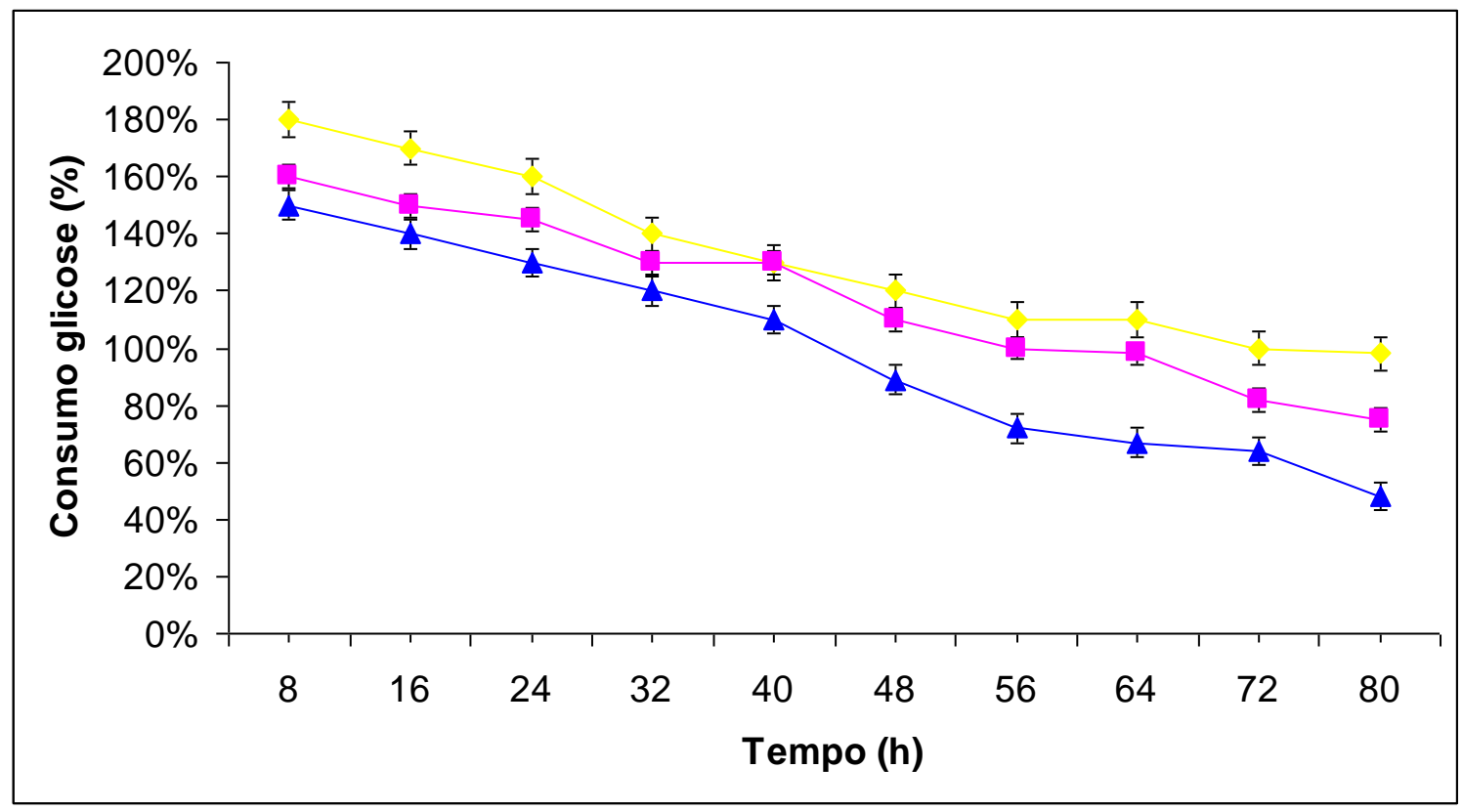

Figura 25. Gráfico do consumo de glicose do ensaio de fermentação dos clones YPH252/pMA91 spt15*

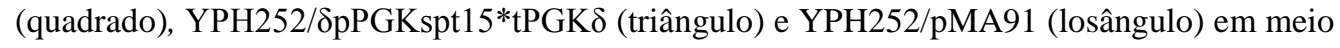
SD-THUAL (20\% de glicose), cultivadas em estufa, a $28{ }^{\circ} \mathrm{C}$, por 80 horas. 
Foi realizada uma avaliação quantitativa da produção de etanol pelos clones

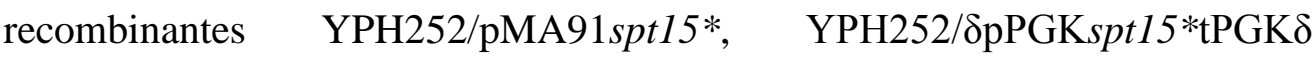
YPH252/pMA91 em meio SD-THUAL contendo 5\% glicose (Figura 26) e 20\% glicose (Figura 27), conforme descrito em Material e Métodos (item 3.23).

Os resultados obtidos indicam que as linhagens recombinantes YPH252/pMA91spt15* e YPH252/סpPGKspt15*tPGK $\delta$ apresentam incrementos positivos na capacidade de produção de etanol, a partir de $5 \%$ de glicose ou a partir de $20 \%$ de glicose, em relação à linhagem original hospedeira YPH252/pMA91 (controle) (Figuras 26 e 27).

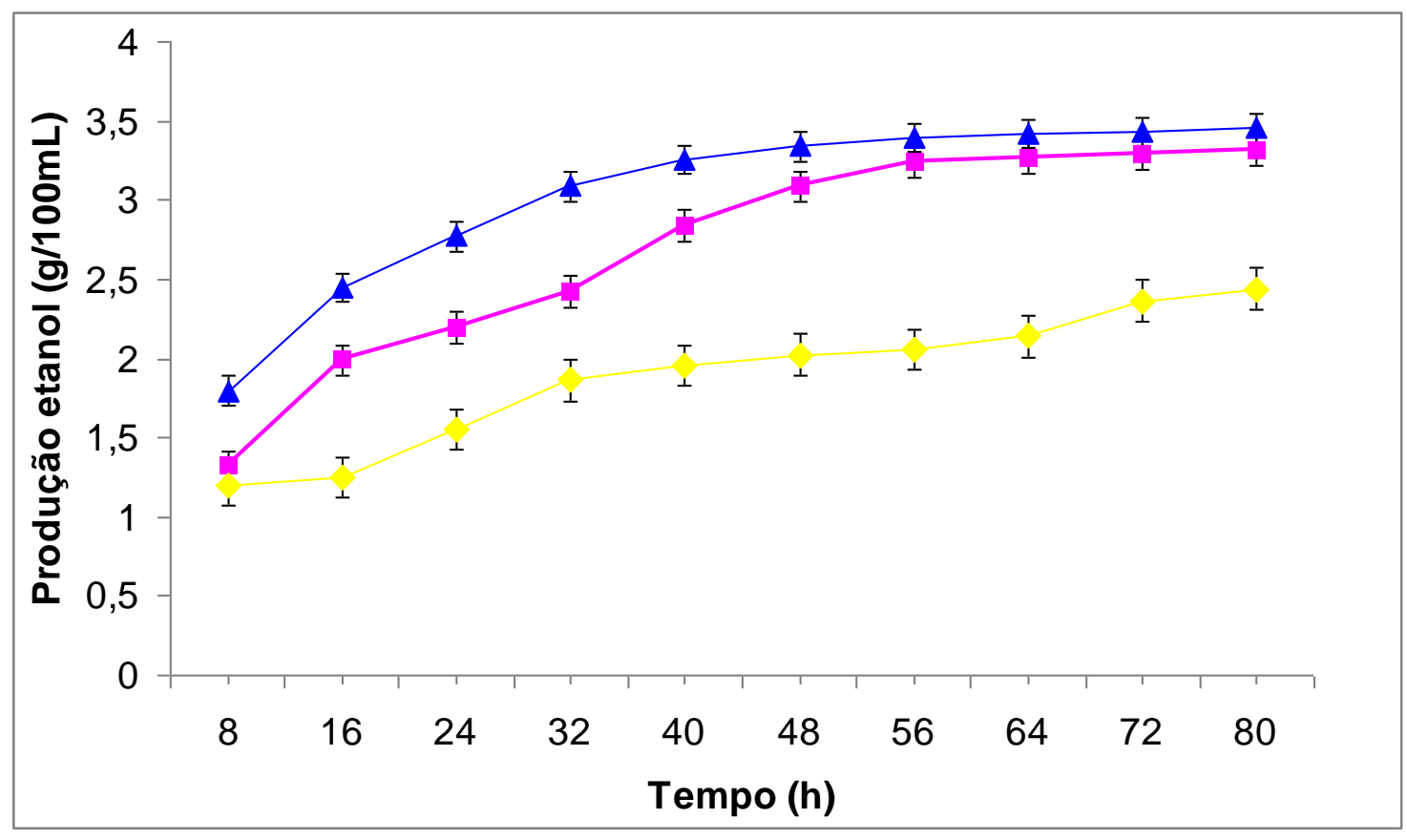

Figura 26. Gráfico de produção de etanol pelas linhagens recombinantes YPH252/pMA91spt15*

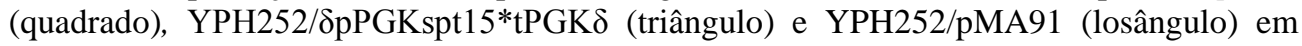
provetas contendo $40 \mathrm{ml}$ de meio SD-THUAL (5\% de glicose), incubadas em estufa à 28 ${ }^{\circ} \mathrm{C}$. 


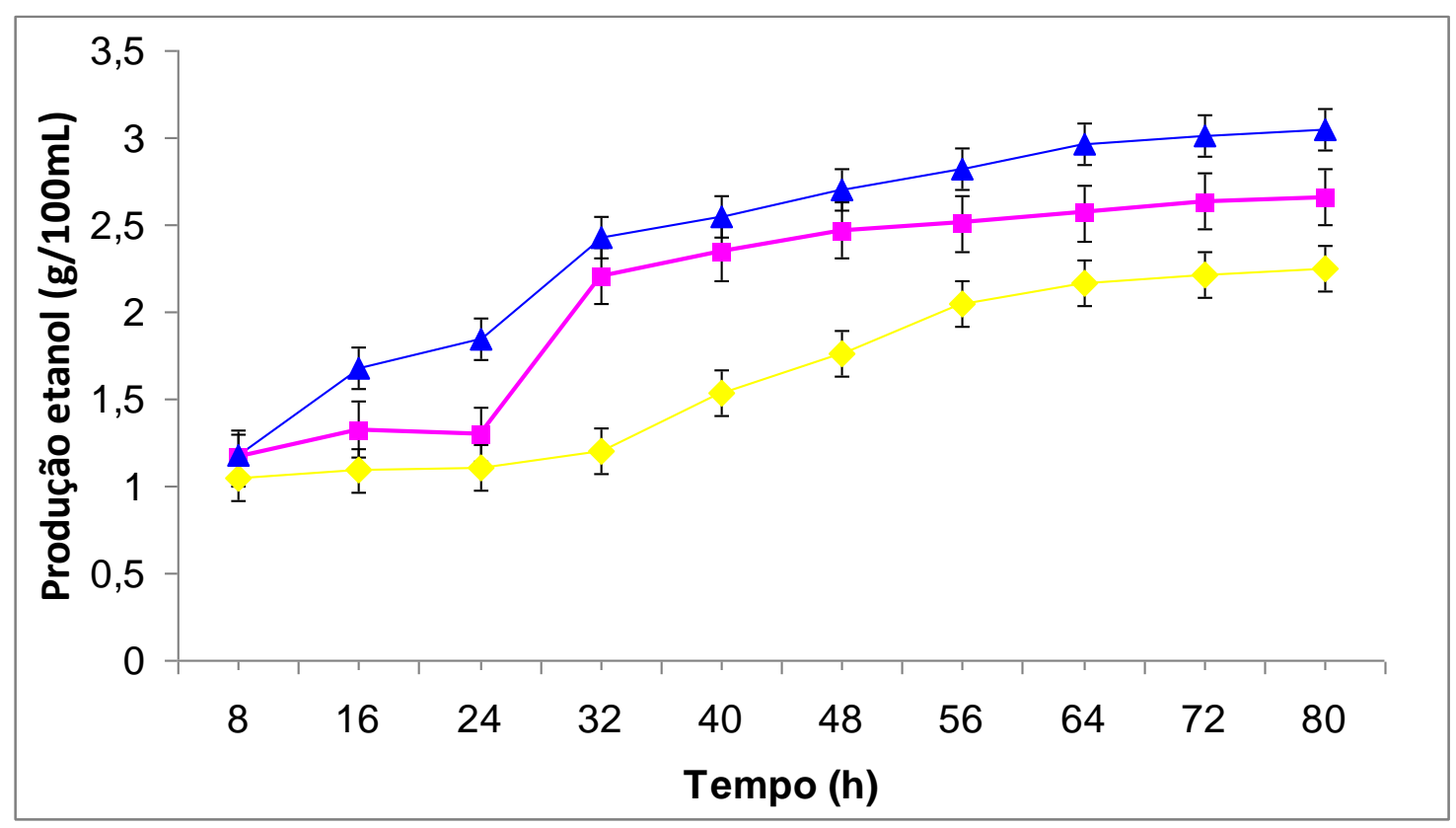

Figura 27. Gráfico de produção de etanol pelas linhagens recombinnates YPH252/pMA91spt15*

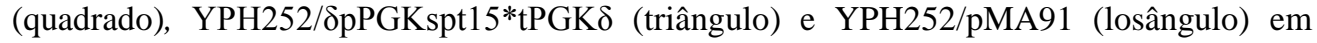
provetas contendo $40 \mathrm{ml}$ de meio SD-THUAL (20\% de glicose), incubadas em estufa à 28 ${ }^{\circ} \mathrm{C}$.

\subsection{Análise da seqüência do alelo SPT15 da linhagem S. cerevisiae industrial PE-2}

O gene SPT15 da linhagem de levedura industrial PE-2 e da linhagem de levedura laboratorial S288C foram amplificados por PCR, usando os oligonucleotídeos iniciadores KPP1 $1_{\mathrm{Fw}}$ e KPP5 $5_{\mathrm{Rv}}$ (Tabela 4) e como molde o DNA total de cada uma destas linhagens (Material e Métodos, item 3.14); e, suas seqüências nucleotídicas obtidas foram alinhadas e comparadas.

Foi verificado $100 \%$ de identidade nas seqüências dos alelos SPT15 das linhagens S288C e PE-2. Isto permite que se criem ótimas perspectivas para um trabalho futuro de inserção de cópias do alelo $\operatorname{spt} 15^{*}$ no genoma das linhagens $S$. cerevisiae industriais. 


\section{CONCLUSÕES}

- Os resultados obtidos indicam superioridade fermentativa, o consumo mais rápido de glicose e o maior rendimento de produção de etanol da linhagem S. cerevisiae

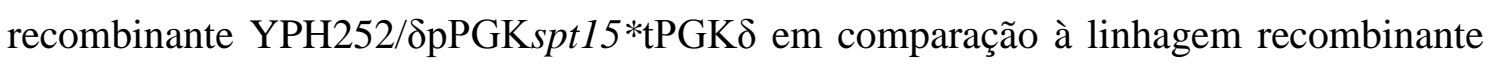
YPH252/pMA91spt15* e esta, por sua vez, foi superior à linhagem YPH252/pMA91 (controle negativo, com genoma equivalente ao da linhagem hospedeira);

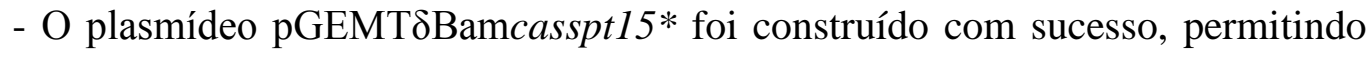
em trabalhos futuros a obtenção de clones recombinantes $S$. cerevisiae derivadas de linhagens selvagens com cópias de $\operatorname{spt} 15 *$ inseridas em seu genoma;

- O alelo SPT15 presente na linhagem S. cerevisiae industrial PE-2 apresenta $100 \%$ de identidade do alelo da linhagem S288C. Como a linhagem laboratorial apresentou um incremento de sua capacidade de assimilação e fermentação de glicose, ótimos resultados também deverão ser alcançados por transformantes de PE-2 com cópias de $\operatorname{spt} 15 *$ inseridas no genoma.

- Para a confirmação e determinação do ganho de capacidade de produção de etanol pelas novas linhagens recombinantes propostas neste trabalho, se fará necessário o desenvolvimento de ensaios de fermentação em biorreator, onde os vários parâmetros padrão são acompanhados e avaliados com precisão. Isto porque principalmente linhagem S. cerevisiae PE-2 já é ótima produtora de etanol e pequenos incrementos da capacidade de produção são de extrema importância, porém demandam capazes de analise com alta precisão, para sua confiabilidade. 


\section{REFERÊNCIAS ${ }^{*}$}

Alper H, Moxley J, Nevoigt E, Fink GR, Stephanopoulos G. Engineering yeast transcription machinery for improved ethanol tolerance and production. Science. 2006; 134:1565-1568.

Ausubel FM, Brent R, Kingston RE, Moore DD, Seidman JG, Smith JA, Struhl K. Short Protocols in Molecular Biology. Harvard: Medical School; 1992. Cap. 13.

Baker SP, Grant PA. The SAGA continues: expanding the cellular role of a transcriptional co-activator complex. Nature. 2007;13:5329-5340.

Basso LC, Amorim HV, Oliveira AJ, Lopes, ML. Yeast Selection for fuel ethanol production in Brazil. FEMS Yeast Res. 2008;8:1155-1163.

Becker DM, Guarente, L. High-efficiency transformation of yeast by eletroporation. Methods Enzymol. 1991;194:182-186.

Beggs JD. Transformation of yeast by a replicating hybrid plasmid. Nature. 1978;275:104-108.

Biddick RK, Law GL, Chin KKB, Young ET. The Transcriptional Coactivators SAGA, SWI/SNF, and Mediator Make Distinct Contributions to Activation of Glucoserepressed Genes. J Biol Chem. 2008;283:33101-33109.

Bjornsdottir $G$ and Myers LC. Minimal components of the RNA polymerase II transcription apparatus determine the consensus TATA box. Nucleic Acids Res. 2008;36:2906-2916.

Boeke JD, Garfinkel DJ, Styles CA, Fink GR. Ty elements transpose through an RNA intermediate. Cell. 1985;40:491-500

Boeke JD, XU H, Fink GR. A general method for the chromosomal amplification of genes in yeast. Science. 1988;239:280-282

Boeke JD, Sandmeyer SB. Yeast Transposable elements, by Broach JR, Pringle JR, Jones E. W. The Molecular and cellular of the yeast Saccharomyces. New York: Cold Spring Harbor Press; 1991. p. 1:193-261.

Botstein D, Davis RW. Principles and practice of recombinant DNA research with yeast. In: Strathern JN, Jones EW, Browach JR. The molecular biology of the yeast Saccharomyces cerevisiae: metabolism and gene expression. New York: Cold Spring Harbor Laboratory;1982. p-607-637.

\section{*De acordo com: \\ International Committee of Medical Journal \\ Editors. Uniform requirements for manuscripts submitted to Bomedical Journal: \\ Sample references. Available from: http://www.icmje.org[2007 May 22].}


Buratowski S, Hahn S, Sharp PA, Guarente, L. Five intermediate complexes in transcription initiation by RNA polymerase II. Cell. 1989;56:549-561.

Burgers PMJ, Percival KJ. Transformation of yeast spheroplasts without cell fusion. Anal Biochem. 1987;163:391-397.

Cang Y, Auble DT, Prelich G. A new regulatory domain on the TATA-binding protein. EMBO J. 1999;23:6662-6671.

Camargo ME. Construção de um vetor para transformar levedura através da disrupção do gene CAN1 [dissertação (Mestrado em Microbiologia)]. São Paulo (Brasil): Instituto de Ciências Biomédicas da Universidade de São Paulo; 1994.

Camargo ME. Sistema para transformação de leveduras industriais e detecção de atividade recombinogênica [Tese (Doutorado em Microbiologia)]. São Paulo (Brasil): Instituto de Ciências Biomédicas da Universidade de São Paulo; 2000.

Cameron JR, Loh EY, Davis RW. Evidence for transposition of dispersed repetitive DNA families in yeast. Cell. 1979;4:739-751.

Chasman DI, Flaherty KM, Sharp PA and Kornberg. Crystal structure of yeast TATAbinding protein and model for interaction with DNA. Proc Natl Acad Sci USA. 1993;90:8174-8178.

Costanza MC, Fox TD. Transformation of yeast by agitation with glass beads. Genetics. 1989;120:667-670.

Davison BL, Egly J, Mulvihill ER, Chambon P. Formation of stable preinitiation complexes between eukaryotic class B transcription factors and promoter sequences. Nature. 1983;301:680-686.

Duno M, Bendixen C, Krejci L, Thomsen B. Targeted deletion created in yeast vectors by recombination excision. Nucleic Acids Res. 1999;27(8):e1.

Eisenmann DM, Dollard C and Winston F. SPT15, the gene encoding the Yeast TATA binding factor TFIID, is required for normal transcription initiation in vivo. Cell. 1989;58:1183-1191.

Eisenmann DM, Arnd KM, Ricupero SL, Rooney JW and Winston F. SPT3 interacts with TFIID to allow normal transcription in Saccharomyces cerevisiae. Genes Dev. 1992;6:1319-1331.

Farrell AE, Plevin RJ, Turner BT, Jones AD, O'hare M, Kammen DM. Ethanol can contribute to energy and environmental goals. Science. 2006;311:506-508.

Fire A, Samuels M, Sharp PA. Interactions between RNA polymerase II, factors, and template leading to accurate transcription. J Biol Chem. 1984;259:2509-2516. 
Fujii T, Kondo K, Shimizu F, Sone H, Tanaka J, Inoue T. Application of a ribosomal DNA integration vector in the construction of a brewer's yeast having $\alpha$-acetolactate decarboxylase activity. Appl Environ Microbiol. 1990;56:997-1003.

Garfinkel DJ. Genome evolution mediated by Ty elements in Saccharomyces. Cytogenet. Genome Res. 2005;110:63-69.

Gietz D, Jean ST, Woods RA, Schiestl RH. Improved method for high efficiency transformation of intact yeast cells. Nucl Acids Res. 1992;20:1425.

Gietz D, Schiestl RH. Transforming yeast with DNA. Methods in Molecular and Cellular Biology. 1995;5:255-269.

Gietz RD, Woods RA. Genetic transformation of yeast. Bio Techniques. 2001;30:816831.

Goffeau A, Barrell B G, Bussey H, Davis R W, Dujon B, Feldmann H, Galibert F, Hoheisel J D, Jacq C, Johnston M, Louis E J, Mewes H W, Murakami Y, Philippsen P, Tettelin H, Oliver S G. Life with 6000 genes. Science. 1996;274:546-567.

Goffeau A, Park J, Paulsen IT, Jonniaux JL, Dinh T, Mondant P, Saier MHJR. Multidrug-resistant transport proteins in yeast: complete inventory and phylogenetic characterization of yeast open reading frames with the major facilitator superfamily. Yeast. 1997;13:43-54.

Goldemberg J. Ethanol for a sustainable energy future. Science. 2007;315:808-810.

Guerra OG, Rubio IG, Da Silva Filho CG, Bertoni RA, Dos Santos Govea EC, Vicente EJ. A novel system of genetic transformation allows multiple integrations of a desired gene in Saccharomyces cerevisiae chromosomes. J microbiol methods. 2006;3:437-445.

Griffith AJF, Miller JH, Suzuki DT, Levontin, RC, Gelbart WM. An introduction of genetics analysis. 7. ed. Lord: WH freeman; 1993. v. 5. cap.13

Hadfield C, Raina KK, Shashi-menon K, Mount RC. The expression and performance of cloned genes in yeast. Micol Res. 1993;97:897-944.

Hahn S, Buratowski S, Sharp PA, Guarente L. Isolation of the Gene Encoding the Yeast TATA Binding Protein TFIID: A Gene Identical to the SPT15 Suppressor of Ty Element Insertions. Cell. 1989;58:1173-1181.

Hahn S. Structure and mechanism of the RNA Polymerase II transcription machinery. Nat Struct Mol Biol. 2004;11:394-403.

Hammond JRM. Brewers' Yeast. In: Rose AH, Harrison JS. The Yeast. 2. ed. London: Academic Press; 1993. v. 5. cap. 2.

Hanahan D. Studies on transformation of E. coli with plasmids. J Mol Biol. 1983; 166:557-580. 
Hill J, Nelson E, Tilman D, Polasky S, Tiffany D. Environmental, economic, and energetic costs and benefits of biodiesel and ethanol biofuels. Proc Natl Acad Sci USA. 2006;103:11206-11210.

Heckman KL, Pease LR. Gene splicing and mutagenesis by PCR-driven overlap extension. Nature. 2007; 2:924-932.

Hinnen A, Hick JB, Fink GR. Transformation of yeast. Proc Natl Acad Sci USA. 1978;75:1929-1933.

Huisinga KL, Pugh BF. A Genome-Wide Housekeeping Role for TFIID and a Highly Regulated Stress-Related Role for SAGA in Saccharomyces cerevisiae. Mol Cell. 2004;13:573-585.

Hou L, Cao X, Wang, LU M. Effect of overexpression of transcription factors on the fermentation properties of Saccharomyces cerevisiae industrial strains. Lett Appl Microbiol. 2009;49:14-19.

Huisinga KL, Pugh BF, A Genome-Wide Housekeeping Role for TFIID and a Highly Regulated Stress-Related Role for SAGA in Saccharomyces cerevisiae. Mol Cell. 2004;13:573-585.

Huisinga KL, Pugh BF. A TATA binding protein regulatory network that governs transcription complex assembly. Genome Biol. 2007; 8:R46.

Ito H, Fukuda Y, Murata K, Kimura A. Transformation of intacts yeast cell treated with álcali cations. J Bacteriol. 1983;153:163-168.

Jimenez A, Davis J. Expression of a transposable antibiotic resistance element in Saccharomyces. Nature. 1980;287:869-871.

Kim JM, Vanguri S, Boeke JD, Gabriel A, Voytas DF. Transposable elements and genome organization: a comprehensive survey of retrotransposons revealed by the complete Saccharomyces cerevisiae genome sequence. Genome Res. 1998;5:464-78.

Kou H, Irvin JD, Huisinga KL, Mitra M and Pugh BF. Strutural and Functional Analysis of Mutations Along the Crystallographic Dimmer Interface of the Yeast TATA Binding Protein. Mol Cell Biol. 2003;23:3186-3201.

Kurtzman CP. Molecular taxonomy of the yeast. Yeast. 1994;10:1727-40.

Kukuruzinska MA, Bergh MLE, Jackson BJ. Protein glycosylation in yeast: transcript heterogeneity of the ALG7 gene. Proc Natl Acad Sci USA. 1987;56:915-944.

Lee DK, Dejong J, Hashimoto S, Horikoshi M, Roeder RG. TFIIA Induces Conformational Changes in TFIID via Interactions with the Basic Repeat. Mol Cell Biol. 1992;12:5189-5196.

Legras J, Karst F. Optimisation of interdelta analysis for Saccharomyces cerevisiae strain characterization. Mol Cell Biol. 2003;221:249-255. 
Lopes TS, Klootwijk J, Veenstra AE, Van Der Aar P, Van Heerikhizen H, Raué HA, Planta RJ. High-copy-number integration into the ribosomal DNA of Saccharomyces cerevisiae: a new vector for high-level expression. Gene. 1989;79:199-206.

Lopes TS, Hakkaart GJAJ, Koerts BL, Raué HA. Planta, R. J. Mechanism of high-copynumber integration of pMIRY-type vectors into the ribosomal DNA Saccharomyces cerevisiae. Gene. 1991;105:83-90.

Martinez E, Chiang C, Ge Hui and Roeder RG. TATA-binding protein-associated factor(s) in TFIID function through the initiator to direct basal transcription from a TATA-less class II promoter. EMBO J. 1994;13:3115-3126.

Meilhoc E, Masson JM, Tessie J. High efficiency transformation of intact yeast cells by electroporation. Bio Technol. 1990;8:223-237.

Mellor J, Dobson MJ, Roberts NA, Tuite MF, Emtage JS, White S, Lowe PA, Patel T, Kingsman AJ, Kigsmans SM. Efficient synthesis of enzimatically active calf chymosin in Saccharomyces cerevisiae. Gene. 1998;24:1-14.

Miller $\mathrm{CH}$, Kowalski D. Cis-acting components in the replication origin from ribosomal DNA of Saccharomyces cerevisiae. Mol Cell Biol. 1993;13:5360-5369.

Miyamoto C, Chizzonite R, Crowl R, Rupprecht K, Kramer R, Schaber M, Kumar G, Poonian M, Ju G. Molecular cloning and regulated expression of the human c-myc gene in Escherichia and Saccharomyces: comparison of the products. Proc Natl Acad Sci USA. 1985;82:7732-7735.

Mohibullah N, Hahn S. Site-especific cross-linking of TBP in vivo and in vitro reveals a direct functional interaction with the SAGA subunit Spt3. Genes Dev. 2008;22:29943006.

Orr-weaver TL, Szostak JW, Rothstein RJ. Genetic application of yeast transformation with linear and gapped plasmids. Methods Enzymol. 1983;101:228-230.

Plant EP, Goodwin TJ, Poulter RT. Tca5, a Ty5-like retrotransposon from Candida albicans. Yeast. 2000;16(16):1509-1518.

Prado F, Aguilera A. New in-vivo cloning methods by homologous recombination in yeast. Curr Genet. 1994;25:180-193.

Rodionov YV, Keppen OI, Sukhacheva MV. A Photometric Assay for Ethanol. Appl Biochem and Microbiol. 2002;38:395-396.

Romanos MA, Scorer CA, Clare JJ. Foreign gene expression in yeast a reiew. Yeast. 1992;8:423-488.

Rose MD, Broach JR. Cloning genes by complementation in yeast. Methods Enzymol. 1991;194:195-230. 
Rothstein RJ. Targeting, disruption, replacement, and allele rescue: integrative DNA transformation in yeast. Methods Enzymol. 1991;194:281-301.

Rubio IGS. Novos vetores de rDNA - Transformação e co-transformação de Saccharomyces cerevisiae, levedura isolada de industriais e da biodiversidade amazônica [tese (Doutorado em Microbiologia)]. São Paulo (Brasil): Instituto de Ciências Biomédicas da Universidade de São Paulo; 2001.

Sambrook J, Frisch EF, Maniatis T. Molecular cloning: a laboratory manual. New York: Cold Spring Harbor laboratory Press; 1989.

Sambrook J, Russel DW. Molecular cloning: a laboratory manual. New York: Cold spring Harbor Laboratory Press; 2001.

Salgado AM, Folly ROM, Valdman B, Cos O, Valero F. Colorimetric method for determination of ethanol by flow injection analysis. Biotechnol Lett. 2000;22:327-330.

Sermwittayawong D, Tan S, SAGA binds TBP via its Spt8 subunit in competition with DNA: implications for TBP recruitment. EMBO J. 2006;25:3791-3800.

Sherman F, Fink GR, Lawrence CW. Methods in yeast genetics: laboratory manual. Cold Spring harbor. New York: Cold Spring Laboratory. 1979.

Sikorski SR \& Hieter P. A system of shuttle vectors and yeast host strains designed for efficient manipulation of DNA in Saccharomyces cerevisiae. Genetics. 1989;122:19-27.

Tora L, Timmers HTHM. The TATA box regulates TATA-binding protein (TBP) dynamics in vivo. Cell Press. 2010;35(6):309-314.

Voorst FV, Houghton-larsen J, Jonson L, Kielland-brandt MC. Genome-wide identification of genes required for growth of Saccharomyces cerevisiae under ethanol stress. Yeast. 2006;2:351.

Voytas DF. Retroelements in genome organization. Science. 1996;274:737-738.

Walker GM. Yeast Phisiology and Biotechnology. New York: John Wily \& Sons. 1998.

Yamaguchi Y, Narita T, Inukai N, Wada T, Handa H. SPT Genes: key Players in the Regulation of Transcription, Chromatin Structure and Other Cellular Processes. J Biochem. 2001;129:185-191.

Yamamoto T, Moerschell RP, Wakem LP, Ferguson D, Sherman F. Parameters affecting the frequencies of transformation and co-transformation with synthetic oligonucleotides in yeast. Yeast. 1992;8:935-948.

Yotov WV, Moreau A, St-amaud R. The alpha chain of the nascent polypeptide associated complex functions as a transcriptional coativator. Mol Cell Biol. 1998;18:1303-1311. 
Zheng H, Liu H, Chen S, Lu Z, Zhang Z, Dai-wen Pang, Xie Z and Shen P. Yeast transformation process studied by fluorescence ladeling technique . Bioconjug chem. 2005; 16:250-254. 


\section{ANEXO \\ Seqüência alinhada do gene SPT15 e do alelo triplo mutado spt15\%.}

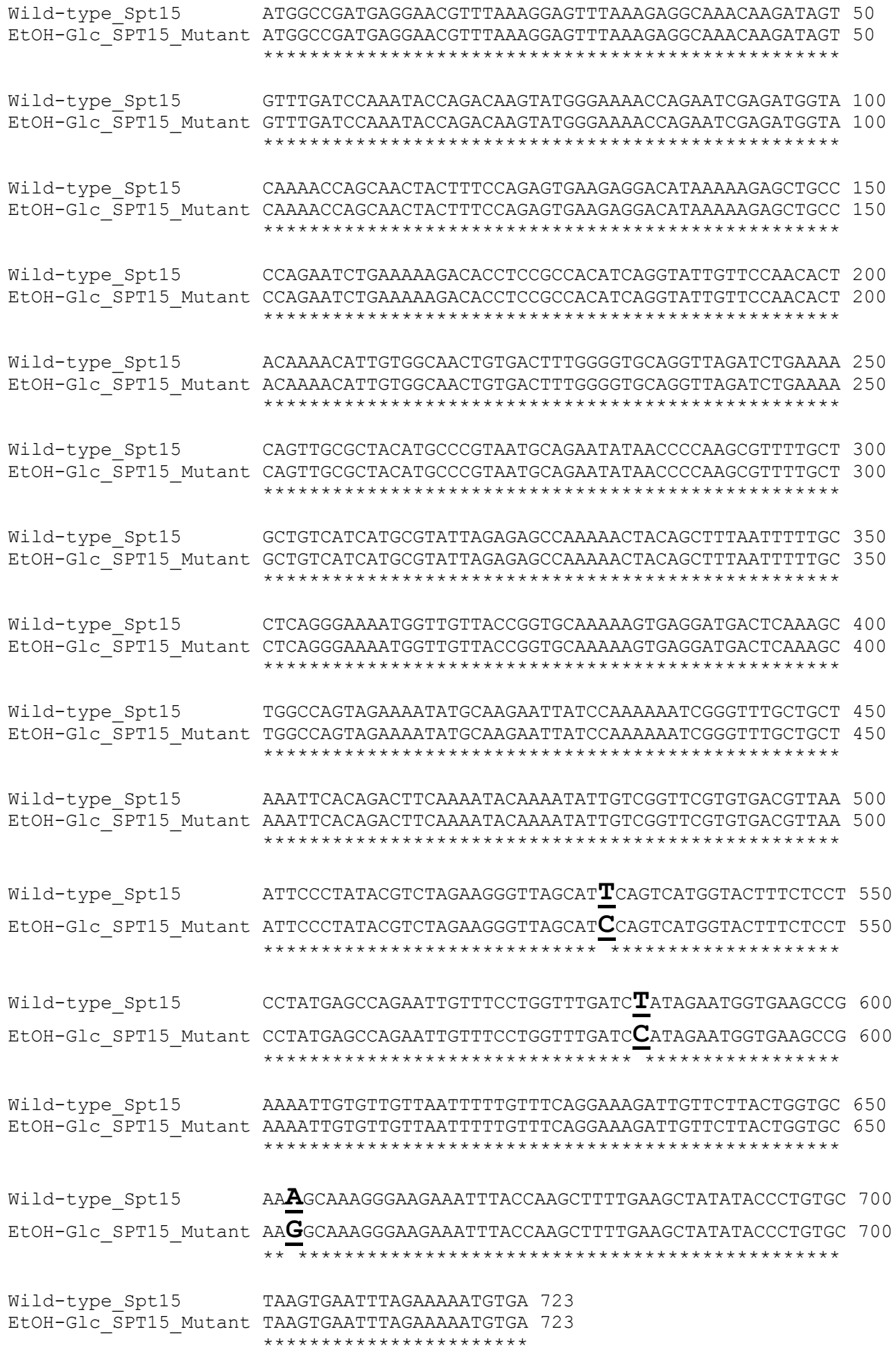

